\title{
De bijzondere positie van de overheid in het Nederlandse privaatrecht
}

\section{De tweewegenleer en het overheidsovereenkomstenrecht}

\author{
Pim Huisman en Frank van Ommeren*
}

\section{Proloog}

\section{I.I Privaatrechtelijk overheidshandelen}

Het thema van de preadviezen is 'het gebruik van privaatrechtelijke technieken in het publiekrecht'. Reeds op het eerste gezicht is het gebruik van het privaatrecht door de overheid vooral problematisch als er tevens publiekrechtelijke bevoegdheden voorhanden zijn. Die zijn immers niet voor niets aan de overheid toegekend. Opmerkelijk genoeg is echter helemaal niet zo duidelijk wat het publiekrecht precies voor het bestaan en de omvang van het hanteren van privaatrechtelijke middelen door de overheid betekent.

De privaatrechtelijke weg kan in verschillende verhoudingen tot het publiekrecht staan. Denkbaar is dat de overheid het gebruik van privaatrechtelijke bevoegdheden prefereert als alternatief voor de publiekrechtelijke. Evenzeer komt het voor dat de overheid het wenselijk acht privaatrechtelijke middelen te gebruiken in aanvulling op de uitoefening van publiekrechtelijke bevoegdheden. In beide gevallen rijst de vraag of en in hoeverre het de overheid toegestaan is het privaatrecht aldus te gebruiken.

\section{I.2 Aanleidingen en actualiteiten}

Gelede rechtsorde en governance-benadering

De ruimte voor het gebruik van privaatrechtelijke procedures in het publiekrecht behoort tot de zeer klassieke themata van het recht, waaraan al meer dan een eeuw bijzondere aandacht wordt besteed. Dat er voortdurend belangstelling is voor de verhouding tussen publiek- en privaatrecht heeft enerzijds te maken met de gerichtheid op de aard van het rechtssysteem als coherent geheel en de eigenstandige waarde

* Respectievelijk universitair docent en hoogleraar bij de afdeling Staats- en bestuursrecht van de Vrije Universiteit te Amsterdam.

Wij bedanken graag Chris Jansen, Gerdy Jurgens, Richard Neerhof en Johan Wolswinkel voor hun commentaar op (delen van) de conceptversie. 
die met name continentale juristen toekennen aan de consistentie van het recht. Anderzijds wordt deze belangstelling ongetwijfeld veroorzaakt door zaken die ten dele buiten het recht liggen. Meer in het algemeen vraagt in onze moderne samenleving immers de verhouding tussen de publieke en private sfeer - mede door de veranderende rol van de overheid en andere instellingen die een publieke taak vervullen - om hernieuwde aandacht. Het recht weerspiegelt deze veranderende verhoudingen.

Voorts is het - terecht - steeds meer gebruikelijk het recht niet meer louter te analyseren als van elkaar losstaande en te scheiden compartimenten, maar veeleer te beschouwen als een integraal geheel, waarvan met elkaar in verband staande onderdelen deel uitmaken: een zogeheten gelede rechtsorde. In die rechtsorde - men spreekt ook wel over een 'gelaagde' of 'meergelaagde' rechtsorde ${ }^{\mathrm{I}}$ - beïnvloeden die onderdelen elkaar niet alleen, maar zijn zij ook gebaseerd op enige gemeenschappelijke juridische principes. ${ }^{2}$ Op grond van de wens het recht te beschouwen als een consistent geheel, moet in die rechtsorde - onder andere - het privaatrechtelijk overheidshandelen zijn eigen plaats hebben. Het valt buiten de reikwijdte van deze bijdrage om op die exacte plaatsbepaling in te gaan, maar de behoefte daaraan dwingt allereerst tot het preciezer in kaart brengen en doordenken van vragen op het grensvlak. De vraag naar de ruimte voor de privaatrechtelijke procedures in het publiekrecht, vormt daarvan bij uitstek een voorbeeld.

Een bijzondere aanleiding om juist in deze tijd opnieuw naar de ruimte voor het privaatrechtelijke overheidshandelen te kijken, is de aanhoudende wens van de overheid om gebruik te maken van alternatieve instrumenten. De behoefte daaraan wordt veroorzaakt doordat de overheid bij de uitvoering van haar taken op uiteenlopende manieren tegen allerlei grenzen en beperkingen aanloopt. Daardoor acht zij het wenselijk te gaan zoeken naar alternatieven om de publieke taak op een betere manier te kunnen vervullen. Dat kan overigens óók doordat andere partijen dan de overheid zich de zorg voor de publieke taak aantrekken.

In rechtswetenschappelijke kring wordt dit zoeken naar alternatieven tegenwoordig wel beschouwd als een aspect van de law and governance-benadering of de new governance-benadering. ${ }^{3}$ De governance-benadering behelst een bestudering van het fenomeen van het besturen waarin de bestuurskracht in de samenleving veel breder wordt beschouwd dan die van de overheid met haar klassieke instrumentarium. In deze, sterk op effectiviteit gerichte, benadering staat de vraag centraal welke andere instrumenten en gedaanten de overheid kan aannemen om haar taken op verschillende beleidsterreinen te realiseren. Wat het recht - zo men wil 'law' aan de governance-benadering toevoegt, is de nadruk op de rechtmatigheidsen behoorlijkheidskant en hoe die te organiseren: in hoeverre is het de overheid geoorloofd van de alternatieve instrumenten gebruik te maken en aan de hand van

Zie voor het accent op de meergelaagdheid met name: W. van Gerven \& S. Lierman, Algemeen deel. Veertig jaar later, Privaat- en publiekrecht in een meergelaagd kader van regelgeving, rechtsvorming en regeltoepassing, Deventer: Kluwer 2010.

2 Zie voor het accent op de gemeenschappelijke normen met name: Dawn Oliver, Common Values and the Public-Private Divide, London: Butterworths 1999 en M.W. Scheltema \& M. Scheltema, Gemeenschappelijk recht. Wisselwerking tussen publiek- en privaatrecht, Deventer: Kluwer 2013.

3 Vgl. o.a. G. de Burca \& J. Scott (eds.), Law and New Governance in the EU and the US, Oxford/Portland Oregon: Hart Publishing 2006. 
welke maatstaven moet zulks worden beoordeeld? Dat brengt onzes inziens de verhoudingen weer in balans: wanneer louter gekeken zou worden naar 'wat werkt', wordt een normatief beoordelingskader terzijde geschoven. ${ }^{4}$ Uiteindelijk is de samenleving daarmee niet gediend. De normatieve invalshoek brengt met zich dat ook de verhouding tussen publiek- en privaatrecht wordt geraakt. ${ }^{5}$

\section{Modern overheidscontractenrecht}

De actualiteit biedt bijzonder veel aanleiding om juist op de rol en de positie van de overheidsovereenkomst dieper in te gaan. In internationaal verband trekt het overheidsovereenkomstenrecht recent steeds meer wetenschappelijke aandacht, hetgeen mede komt doordat in het internationale juridische discours de overheidsovereenkomst beschouwd wordt als een fundamenteel overheidsinstrument, dat evenwel door zijn grensvlakpositie in verschillende rechtsstelsels uiteenlopend wordt benaderd en waarvan (mede daardoor) de rechtspositie van partijen enigszins onduidelijk is. Te noemen vallen met name het internationale onderzoeksnetwerk Public Contracts in Legal Globalization, dat zich uitsluitend op het overheidscontractenrecht richt en het Research Network on EU Administrative Law (ReNEUAL). ${ }^{6}$ ReNEUAL heeft in het najaar van 2014 zijn zogeheten Model Rules on EU Administrative Procedure openbaar gemaakt. Deze model rules bevatten onder meer een boek over contracts. ${ }^{7}$ De bedoeling van deze Model Rules is primair dat zij van toepassing zijn op de autoriteiten van de Europese Unie, maar verwacht wordt dat zij ook van invloed zullen zijn in de lidstaten.

Ten slotte biedt ook het Nederlandse positieve recht aanleiding juist de figuur van de overheidsovereenkomst nader te beschouwen. Ofschoon de rechter, zowel de burgerlijke rechter als de bestuursrechter, geneigd is de overheidsovereenkomst steevast als een privaatrechtelijke rechtsfiguur te beschouwen, heeft de Hoge Raad betrekkelijk recent - in $201 \mathrm{I}$ - de bevoegdhedenovereenkomst erkend als aparte rechtsfiguur met een gemengd karakter en zijn positie nader afgebakend. ${ }^{8}$

4 Vgl. o.a. B.M.J. van der Meulen, 'Governance in Law: Charting Legal Intuition', in: A.L.B. Colombi Ciacchi a.o. (eds.), Law \& Governance. Beyond the Public-Private Law Divide?, Den Haag: Eleven International Publishing 2013, p. 275 e.v.

5 Zie F.J. van Ommeren, 'De betekenis van de governancebenadering voor het onderscheid tussen publiek- en privaatrecht', in: C.H.C. Overes \& W.J.M. van Veen (red.), Met recht betrokken. Opstellen aangeboden aan prof. mr. T.J. van der Ploeg, Deventer: Kluwer 20I2, p. 2I6 e.v. en F.J. van Ommeren, 'Governance and the Public-Private Law Divide in the Netherlands', in: A.L.B. Colombi Ciacchi a.o. (eds.), Law \& Governance. Beyond the Public-Private Law Divide?, Den Haag: Eleven International Publishing 2013, p. I9 e.v.

6 Zie respectievelijk www.public-contracts.net en www.reneual.eu. Opdat men weet uit welke hoek de wind waait: wij zijn beiden actieve leden van deze netwerken.

7 Zie voor een bespreking van dit boek: F.J. van Ommeren, 'Overheidsovereenkomsten: rechtsvergelijking en de ReNEUAL Model Rules’, in: B. Schueler \& R. Widdershoven, Europeanisering van het algemeen bestuursrecht, Den Haag: Boom Juridische uitgevers 20I4, p. I30 e.v., en voor een bespreking van de gehele Model Rules: F.J. van Ommeren \& C.J. Wolswinkel, 'Naar een Algemene wet bestuursrecht voor de EU', NTB 20I4/23, p. I89 e.v. en H. Addink, 'Europees bestuursrecht in ontwikkeling: op weg naar een Europese Awb', NTB 2014/24, p. I97 e.v.

8 HR 8 juli 20II, AB 20II/298 m.nt. F.J. van Ommeren \& G.A. van der Veen, TBR 20II/202 m.nt. P.J. Huisman (Etam/Zoetermeer). 
Wij beschouwen dit als een stap voorwaarts, maar hij roept ook nieuwe vragen op, waarmee eveneens in de rechtspraktijk wordt geworsteld.

\section{I.3 De ruimte voor de privaatrechtelijke weg}

In dit preadvies staat de vraag centraal of en in hoeverre de overheid de ruimte heeft in plaats van of in aanvulling op het publiekrecht voor de privaatrechtelijke weg te kiezen. Om die vraag goed te kunnen beantwoorden is er behoefte aan een beoordelingskader. In de privaatrechtelijke rechtspraak is een beoordelingskader ontwikkeld dat wel kortweg wordt aangeduid als de doorkruisingsformule. Wij zullen in dit preadvies vooral ingaan op de vraag in hoeverre deze doorkruisingsformule thans wordt toegepast en in hoeverre daarnaast ook andere maatstaven, zoals het legaliteitsbeginsel, worden gehanteerd. Uiteraard zullen wij de gevonden resultaten ook beoordelen, door ons af te vragen wanneer deze formule een zinvolle functie vervult en waar zij wellicht beter kan worden vervangen of aangevuld met andere beoordelingsmaatstaven.

De ene privaatrechtelijke weg is de andere niet. Het kan aanzienlijk verschil maken om wat voor soort privaatrechtelijk overheidshandelen het gaat, welke ruimte de overheid heeft en aan de hand van welke maatstaven dit wordt beoordeeld. Na de bespreking van de vraag in hoeverre er in het algemeen ruimte is voor het gebruik van privaatrechtelijke bevoegdheden door de overheid, zullen wij daarom kort op enige verschillende varianten ingaan, die in de jurisprudentie de nodige aandacht hebben gekregen.

De rechtsfiguur van de overheidsovereenkomst diepen wij vervolgens verder uit. Teneinde de ruimte voor de overheid om gebruik te maken van de overheidsovereenkomst preciezer te kunnen analyseren, verkennen wij de mogelijkheden van een ietwat andere conceptuele indeling van deze rechtsfiguur dan in de literatuur gebruikelijk is. Aan de hand daarvan kan vervolgens de vraag worden beantwoord met behulp van welke maatstaven de ruimte voor de overheidsovereenkomst kan worden beoordeeld: in hoeverre is de doorkruisingsformule daarvoor geschikt en in hoeverre zijn andere beoordelingsmaatstaven meer aangewezen? Wij streven ernaar om per soort overeenkomst in beginsel één beoordelingskader te ontwikkelen. Aangezien het publiekrecht over het algemeen meer is gericht op de waarborging van de belangen van derden dan het privaatrecht, zullen wij in het bijzonder aandacht besteden aan de positie van derden bij de overeenkomst.

\section{I.4 Opbouw van dit preadvies}

Wij beginnen met een bespreking van de tweewegenleer. Uiteraard gaat de aandacht uit naar de betekenis van het Windmill-arrest met zijn formule van de onaanvaardbare doorkruising, zoals die zich in de recente rechtspraak verder heeft ontwikkeld, maar andere relevante maatstaven worden daarbij zeker niet uit het oog verloren (hoofdstuk 2). Nadat het algemene beoordelingskader in beeld is gebracht, wordt in de volgende hoofdstukken dieper ingegaan op het overheidsovereenkomstenrecht. Eerst delen wij overheidsovereenkomsten nader in verschillende soorten in (hoofdstuk 3). Aan de hand van die indeling wordt daarna ingegaan op de vraag welke ruimte de overheid heeft om de verschillende soorten overeenkomsten te 
sluiten en aan de hand van welk soort maatstaven de toelaatbaarheid van de verschillende soorten overheidsovereenkomsten moet worden beoordeeld (hoofdstuk 4). Het preadvies wordt afgesloten met een epiloog (hoofdstuk 5).

\section{De tweewegenleer: via Windmill naar Geschiere en verder}

\section{I Inleiding}

De tweewegenproblematiek heeft betrekking op de vraag of en in hoeverre de overheid de ruimte heeft om in plaats van of in aanvulling op het publiekrecht voor de privaatrechtelijke weg te kiezen. Om die problematiek goed te kunnen doorgronden, is het nodig om in te gaan op de achtergrond van de tweewegenleer en de verhouding met het publiekrecht, in het bijzonder met het oog op de groei van de toegekende publiekrechtelijke bevoegdheden.

Het antwoord op de vraag of en in hoeverre de overheid gebruik mag maken van het privaatrecht wordt tegenwoordig in de praktijk doorgaans welhaast automatisch in verband gebracht met het Windmill-arrest en de daarin geformuleerde doorkruisingsformule. Hoewel niet onjuist, is dat een ietwat te beperkt beoordelingskader. Naast de doorkruisingsformule zijn namelijk andere criteria relevant. In dit hoofdstuk wordt daarom, zoveel mogelijk aan de hand van recente jurisprudentie, ingegaan op de doorkruisingsformule en de huidige functie en betekenis daarvan. Tevens wordt aandacht besteed aan de alternatieve criteria, de rol die zij vervullen en hoe hun verhouding is met de doorkruisingsformule.

$\mathrm{Na}$ dit algemene overzicht gaan wij dieper in op de ruimte die de overheid heeft om bepaalde bevoegdheden toe te kennen aan een privaatrechtelijke rechtspersoon en ook aan de ruimte voor handhaving van wettelijke voorschriften langs privaatrechtelijke weg. De overheidsovereenkomsten krijgen bijzondere aandacht in de volgende hoofdstukken.

\subsection{Tweewegenleer: achtergrond en verhouding met publiekrecht}

De doctrine: keuzevrijheid versus bescherming publiekrechtelijke waarborgen

De fundamentele vraag of de overheid voor de behartiging van haar taken überhaupt wel gebruik mag maken van de privaatrechtelijke weg, gaat uiteraard vooraf aan de vraag in hoeverre zij dat mag. Juist over dit fundament lopen de opvattingen in de $\mathrm{Ne}$ derlandse doctrine sterk uiteen. Zonder uitvoerig op de overvloedige literatuur in te willen gaan, schetsen wij hier kort de twee doctrinaire uitersten. Zij laten goed het spanningsveld zien dat de achtergrond vormt van de tweewegenleer.

Aan de ene kant van het spectrum bevindt zich de opvatting waarin de keuzeurijheid van handelen van de overheid centraal staat. In deze opvatting staat het de overheid in beginsel vrij om van publiekrechtelijke of privaatrechtelijke bevoegdheden gebruik te maken. Het gebruik van het privaatrecht is in deze opvatting overigens niet geheel onbegrensd. Het gebruik van het privaatrecht door de overheid is met name niet mogelijk als de wet een exclusieve regeling bevat waarvan niet mag worden afgeweken. Deze 'ja, tenzij'-benadering vindt vanaf het begin van de twintigste eeuw grote steun en beleeft 
zijn hoogtijdagen in de jaren '50 en '6o. Zij is onder meer te herkennen in het preadvies van Troostwijk voor de Vereniging voor Administratief Recht uit 1956. Zo schrijft hij:

'Zolang de administratie niet met de positieve wetsbepaling in strijd komt (...), er geen sprake is van misbruik van recht en de algemene beginselen van behoorlijk bestuur in acht worden genomen, is er niet de minste reden haar niet de vrije keus tussen de publiekrechtelijke en privaatrechtelijke vorm te laten.' (curs. dzz.) ${ }^{9}$

Aan de andere kant van het spectrum ligt de opvatting dat de overheid nooit privaatrechtelijk mag handelen, omdat dit type handelen per definitie afbreuk doet aan de publiekrechtelijke waarborgen. Door privaatrechtelijk te handelen worden, in deze visie, onder meer het democratiebeginsel, het legaliteitsbeginsel, het specialiteitsbeginsel en de werking van de grondrechten uit het oog verloren. Uitgangspunt van deze opvatting is daarom dat de overheid uitsluitend publiekrechtelijk dient te handelen, omdat slechts dit handelen volledig publiekrechtelijk wordt genormeerd. De nadruk ligt zozeer op het waarborgen van de publieke belangen, dat het in deze lijn van redeneren voor de overheid niet mogelijk moet zijn om te kiezen voor het privaatrecht: als de 'privaatrechtelijke' weg wordt bewandeld, zou dat in wezen als publiekrecht moeten worden beschouwd. In deze benadering zijn er dus eigenlijk geen twee wegen. In het Nederlandse recht is dit standpunt met name in de jaren '9o van de vorige eeuw ingenomen door de zogeheten Maastrichtse school. ${ }^{\text {10 }} \mathrm{Het}$ wordt thans met name gepropageerd door de bewerkers van het bekende bestuursrechtelijke handboek Bestuursrecht in de sociale rechtsstaat. ${ }^{\text {II }}$

Het positieve recht heeft echter steeds een tamelijk eenduidig antwoord gegeven op de fundamentele vraag of de overheid gebruik mag maken van het privaatrecht: aangenomen wordt dat de overheid daartoe in beginsel de ruimte heeft (vgl. voor het vermogensrecht art. 2:I jo. 2:5 BW). Dit neemt niet weg dat wanneer de overheid privaatrechtelijk handelt en er vragen rijzen over in hoeverre deze weg toelaatbaar is, het hier geschetste spanningsveld vrijwel steeds expliciet of impliciet is waar te nemen.

De tweewegenleer en de opkomst van het bestuursrecht

Het privaatrecht kent een langere geschiedenis dan het bestuursrecht. Dat heeft niet alleen gezorgd voor een uitgewerkt stelsel van geschreven en ongeschreven

$9 \quad$ M. Troostwijk, 'Het gebruik maken van burgerrechtelijke vormen bij de behartiging van openbare belangen', in: B. de Goede en M. Troostwijk, Het gebruik maken van burgerrechtelijke vormen bij de behartiging van openbare belangen (VAR preadviezen I956), Haarlem: H.D. Tjeenk Willink \& Zoon N.V. I956, p. 70-7I. Als standaardcitaat terecht aangehaald in H.D. van Wijk/W. Konijnenbelt \& R.M. van Male, Hoofdstukken van bestuursrecht, Deventer: Kluwer 20I4, p. 4I8. Zie eerder met name F.J.A. Huart, 'Misbruik van burgerlijk recht door de administratie', in: Staatsrechtelijke opstellen uitgegeven ter gelegenheid van het aftreden van prof. H. Krabbe, Tweede Deel. Bijdragen van oud-leerlingen, 's-Gravenhage: Martinus Nijhoff 1927 , p. I88 e.v.

Io Zie in dit verband bijvoorbeeld H.J. Simon \& A.Q.C. Tak, 'Het BW als “zwart gat”', NTBR I994, p. I8o, J.M.H.F. Teunissen, Het burgerlijk kleed van de staat (diss. Maastricht), Zwolle: W.E.J. Tjeenk Willink 1996 en A.Q.C. Tak, De overheid in het burgerlijk recht, 's-Gravenhage: VUGA Uitgeverij BV I997, p. 5I4.

II R.J.N. Schlössels \& S.E. Zijlstra, Bestuursrecht in de sociale rechtsstaat, Deventer: Kluwer 20Io, p. 524 e.v. 
privaatrechtelijke rechtsregels, maar ook voor een zekere mate van vertrouwdheid met privaatrechtelijk handelen en op bepaalde terreinen (nog steeds) voor een zekere voorkeur daarvoor. Het hoeft niet te verwonderen dat bij de doctrinaire start van de tweewegenleer het uitgangspunt van keuzevrijheid van handelen voorop stond. Het privaatrechtelijke handelen was immers veelal de enige aangewezen weg, ook waar het de overheid betrof.

De tweewegenleer gaat er - tot op de dag van vandaag - van uit dat het privaatrechtelijke overheidshandelen in beginsel is toegestaan, tenzij er een reden is om het niet geoorloofd te achten. Het is van belang om niet uit het oog te verliezen dat dit een heel ander uitgangspunt is dan in het publiekrecht geldt. Voor publiekrechtelijk handelen is immers het uitgangspunt dat de overheid in beginsel uitsluitend over die bevoegdheden beschikt die haar uitdrukkelijk bij of krachtens de wet zijn toegekend. Dit uitgangspunt is gebaseerd op het legaliteitsbeginsel, dat uitsluitend in het publiekrecht van toepassing is. De uitgangspunten voor de toelaatbaarheid van publiekrechtelijk en privaatrechtelijk overheidshandelen staan dus diametraal tegenover elkaar.

Zoals bekend, is de ontwikkeling van het bestuursrecht pas halverwege de vorige eeuw echt op gang gekomen met een sterke toename van bestuursrechtelijke wetgeving waarin op grote schaal uiteenlopende publiekrechtelijke bevoegdheden aan bestuursorganen werden toegekend. Zij ging bovendien gepaard met de opkomst van een separaat stelsel van algemene bestuursrechtspraak, waarin in het bijzonder ook het ongeschreven bestuursrecht via de algemene beginselen van behoorlijk bestuur sterk tot ontwikkeling kon komen. ${ }^{\text {I2 }}$

Zoals in het navolgende nog meerdere keren aan de orde zal komen, is het gevaar van een overheid die gebruikmaakt van privaatrechtelijke middelen dat de aan haar toevertrouwde publieke belangen niet optimaal worden behartigd. Welke publieke belangen de overheid in een bepaald geval precies dient te behartigen, blijkt in het bijzonder uit de publiekrechtelijke bevoegdheden die bij wettelijk voorschrift aan haar bestuursorganen zijn toegekend. De ruimte die de overheid heeft om de privaatrechtelijke weg te bewandelen kan op een bepaald terrein aanzienlijk worden ingeperkt door de toekenning van publiekrechtelijke bevoegdheden.

Het is dan ook met name de grote golf van bestuursrechtelijke wetgeving - die in de $20^{\mathrm{e}}$ eeuw sterk is aangezwollen en thans nog onverminderd over ons heen komt - die van grote invloed is op de ruimte die er voor de overheid is om de privaatrechtelijke weg te bewandelen. Het lijken als het ware communicerende vaten. De vraag is of naarmate op een bepaald terrein meer publiekrechtelijke bevoegdheden zijn toegekend, zulks ook meer de ruimte reduceert voor de overheid om privaatrechtelijk op te treden. Zijn op een bepaald terrein echter geen of weinig publiekrechtelijke bevoegdheden in het leven geroepen, dan lijkt er meer ruimte voor de overheid om gebruik te maken van de privaatrechtelijke weg. De vraag is hoe deze 'communicatie' verloopt.

I2 Zie meer uitvoerig over de betekenis van deze twee ontwikkelingen voor het privaatrechtelijk overheidshandelen: F.J. van Ommeren, 'Een andere visie op de verhouding tussen publiek- en privaatrecht. Van de "gemene rechtsleer" naar de "gemeenschappelijke rechtsleer", AA 2012, p. 57I, 572. 
Daar komt nog meer bij. Ook het ongeschreven bestuursrecht heeft aan invloed gewonnen. De erkenning en aanvaarding van de betekenis van de algemene beginselen van behoorlijk bestuur in de bestuursrechtspraak heeft, op haar beurt, ook de rechtspraak van de burgerlijke rechter diepgaand beïnvloed, doordat sedert het eind van de jaren '8o van de vorige eeuw deze rechter het privaatrechtelijk overheidshandelen eveneens rechtstreeks is gaan toetsen aan de algemene beginselen van behoorlijk bestuur en andere normen van publiekrechtelijke herkomst. ${ }^{13}$ Ook in de wet is de toepasselijkheid van normen van publiekrechtelijke herkomst op privaatrechtelijk overheidshandelen tot uitdrukking gebracht, zowel in de algemene wetgeving (art. 3:I4 BW en art. 3:I lid $2 \mathrm{Awb}$ ) als in meer specifieke wetgeving, zoals in de Aanbestedingswet 20I2. ${ }^{\mathrm{I}}$ Het is derhalve breed aanvaard dat het privaatrechtelijk overheidsoptreden is onderworpen aan een gemengd rechtsregime met privaatrechtelijke én publiekrechtelijke rechtsregels. Ook deze ontwikkeling heeft eraan bijgedragen dat de ruimte voor de overheid om op geoorloofde wijze langs privaatrechtelijke weg op te treden strenger dan in het verleden is genormeerd en aldus in die zin nader is ingeperkt.

\subsection{De doorkruisingsformule}

\section{Vóór het Windmill-arrest}

Oorspronkelijk hanteerde de Hoge Raad een tamelijk soepele benadering in het toestaan van het gebruik van het privaatrecht door de overheid. De Hoge Raad nam tot uitgangspunt dat de overheid privaatrechtelijk mocht handelen, tenzij de wet een beletsel vormde of sprake was van misbruik van bevoegdheid of feitelijke machtspositie. ${ }^{15}$ Er werd niet snel aangenomen dat er een belemmering was om privaatrechtelijk te handelen. Dat had voor een belangrijk deel te maken met de wijze waarop de wet werd uitgelegd. De omstandigheid dat ter zake een publiekrechtelijke bevoegdheid was toegekend, betekende op zichzelf nog weinig. Slechts als de wettelijke voorziening (meer of minder uitdrukkelijk) exclusief was bedoeld, hetgeen niet vlug werd aangenomen, vormde zij een beletsel. Met andere woorden: de toegekende publiekrechtelijke bevoegdheid vormde doorgaans niet zozeer een verplichting voor het bestuur om haar uit te oefenen, maar een mogelijkheid waarvan niet per se behoefde te worden gebruikgemaakt. Een dergelijke interpretatie van de wet laat relatief veel ruimte voor het gebruik van privaatrechtelijke alternatieven.

Deze benadering stuitte in de doctrine op de hiervoor aangestipte kritiek dat daarmee de publiekrechtelijke waarborgen teveel uit het oog werden verloren. Het Windmill-arrest uit I990, waarin de Hoge Raad een strengere benadering is gaan hanteren, is te beschouwen als een antwoord op deze kritiek.

I3 HR 27 maart I987, AB Klassiek 2009/I3 m.nt. M. Scheltema (Amsterdam/Ikon).

I4 Zie evenwel voor scherpe kritiek op de manier waarop deze beginselen in de Aanbestedingswet 2012 zijn uitgewerkt: M. Scheltema, 'Goede marktwerking en publiekrechtelijke beginselen', in: J.M. Hebly, E.R. Manunza \& M. Scheltema, Beschouwingen naar aanleiding van het wetsvoorstel Aanbestedingswet (preadviezen nr. 38), Den Haag: IBR 20Io, p. I29 e.v.

I5 HR I3 april I962, ARB I962, p. 487 m.nt. J.R. Stellinga, AB Klassiek 2003/9 m.nt. D.A. Lubach (Kruseman) en HR i9 januari I968, ARB I968, p. 585, AB Klassiek 2003/Io m.nt. H.Ph.J.A.M. Hennekens (Eindhoven/Staals). 
In het Windmill-arrest heeft de Hoge Raad overwogen dat wanneer de wet - ingeval de overheid 'bij een publiekrechtelijke regeling ter behartiging van zekere belangen bepaalde bevoegdheden zijn toegekend' - niet voorziet in een antwoord op de vraag of de overheid gebruik mag maken van haar in beginsel krachtens het privaatrecht toekomende bevoegdheden, beoordeeld moet worden of gebruikmaking van de privaatrechtelijke bevoegdheden de betrokken publiekrechtelijke regeling niet op onaanvaardbare wijze doorkruist. ${ }^{16}$ Daarbij moet onder meer worden gelet op:

I. inhoud en strekking van de regeling,

2. de wijze waarop en de mate waarin in het kader van de regeling de belangen van de burgers zijn beschermd, en

3. voorts is van belang of de overheid door gebruikmaking van de publiekrechtelijke regeling een vergelijkbaar resultaat kan bereiken als door gebruikmaking van de privaatrechtelijke bevoegdheid.

De eerste twee ijkpunten moeten volgens de Hoge Raad mede worden bezien tegen de achtergrond van de overige geschreven en ongeschreven regels van publiekrecht.

Voor de toepasselijkheid van de doorkruisingsformule komt het mede aan op de omvang van de privaatrechtelijke bevoegdheden die de overheid heeft. In het Windmill-arrest kent de Hoge Raad een ruime reikwijdte aan de doorkruisingsformule toe, aangezien het bij aan de overheid krachtens het privaatrecht toekomende bevoegdheden gaat om bevoegdheden:

'zoals aan het eigendomsrecht ontleende bevoegdheden, de bevoegdheid overeenkomsten naar burgerlijk recht te sluiten of de bevoegdheid een vordering op grond van een jegens haar gepleegde onrechtmatige daad bij de burgerlijke rechter in te stellen'.

Blijkens het woordje 'zoals' is de hiervoor weergegeven omschrijving niet-limitatief bedoeld. Gevolg hiervan is dat in beginsel al het privaatrechtelijk overheidshandelen onder het bereik van de doorkruisingsformule valt. Daarbij dient bovendien bedacht te worden dat de rechter overheidsovereenkomsten als privaatrechtelijk pleegt te beschouwen, ook de overeenkomsten die in de bestuursrechtelijke literatuur door een aantal auteurs als publiekrechtelijk worden bestempeld.

Voorvraag: voorziet de wet er zelf in?

Voordat de rechter toekomt aan de doorkruisingsformule, gaat hij, indien dit aan de orde is, in op de vraag of de wet zich expliciet uitlaat over de toelaatbaarheid van privaatrechtelijk overheidshandelen (de 'voorvraag'). De publiekrechtelijke regeling voorziet niet vaak in een dergelijk expliciet antwoord.

I6 HR 26 januari I990, NJ I99I/393, AB I990/408 m.nt. G.P. Kleijn, AB Klassiek 2009/I5 m.nt. H.Ph.J.A.M. Hennekens (Windmill). 
Het komt soms voor dat de wet uitdrukkelijk het gebruik van privaatrechtelijke bevoegdheden toestaat. Een voorbeeld biedt art. 4:124 Awb, dat - in navolging van het inmiddels vervallen art. 3 lid 2 Invorderingswet I990 - bepaalt dat het bestuursorgaan ten aanzien van de invordering van bestuurlijke geldschulden ook beschikt over de bevoegdheden die een schuldeiser op grond van het privaatrecht heeft. Daarnaast komt het een heel enkele keer voor dat de wet uitdrukkelijk privaatrechtelijk overheidsoptreden verbiedt. Een van de weinige voorbeelden vormt art. I22 Woningwet, op basis waarvan het niet is toegestaan te contracteren over de omgevingsvergunning voor het bouwen noch over de bouwtechnische eisen.

Bevat de wet een expliciet antwoord op de vraag of privaatrechtelijk handelen is toegestaan, dan is daarmee niet altijd automatisch de kous af. Het komt voor dat er geschillen ontstaan over de reikwijdte van hetgeen wettelijk is toegestaan of verboden. In een dergelijke situatie komt het aan op een interpretatie van de reikwijdte van het wettelijk toegestane gebruik van het privaatrecht. Zo is een terugkerende vraag, ook in recente jurisprudentie, welke privaatrechtelijke bevoegdheden de overheid precies heeft als schuldeiser en of en in hoeverre die bevoegdheden onder de reikwijdte van de hiervoor genoemde artikelen 3 lid 2 (oud) Invorderingswet I990 en 4:I24 Awb vallen. ${ }^{17}$ Ook de reikwijdte van art. 122 Woningwet wordt in de rechtspraak afgetast. ${ }^{18}$

Geeft de wettekst uitdrukkelijk antwoord op de vraag of gebruik van het privaatrecht door de overheid is toegestaan, dan komt de rechter niet aan de doorkruisingsformule toe; dat is dan ook niet meer nodig. De Hoge Raad kijkt bij de beantwoording van de 'voorvraag' niet louter naar de wettekst, maar betrekt daarbij eveneens - indien nodig voor de interpretatie daarvan - de inhoud en strekking van de regeling. ${ }^{19}$

Als in de wet expliciet is aangegeven dat de privaatrechtelijke weg is toegestaan, betekent dit niet automatisch dat de wetgever daarmee een voorkeur aangeeft voor het gebruik van deze weg wanneer de publiekrechtelijke weg eveneens tot de mogelijkheden behoort. Opmerkelijk genoeg wordt in de literatuur een wettelijke voorziening als die van het hiervoor aangehaalde art. 4:124 Awb ook wel anders begrepen. Zo wordt wel de opvatting gehuldigd dat als een invorderingsbeschikking kan worden genomen, het bestuursorgaan in beginsel gebruik zou moeten maken van de bestuursrechtelijke invorderingsprocedure en slechts gemotiveerd voor invordering langs privaatrechtelijke weg zou kunnen kiezen. ${ }^{20}$ Maar ook het - tegengestelde - standpunt komen we tegen, namelijk dat volgens de tekst van de Awb als uitgangspunt geldt dat voor invordering de weg naar de burgerlijke rechter dient te worden gevolgd. ${ }^{2 I}$ Art. 4:I24 Awb brengt echter slechts tot uitdrukking dat het

I7 Zie onder meer HR 28 juni I996, NJ I997/Io2 m.nt. J.W. Zwemmer (M-groep/Ontvanger), HR 2I februari 20I4, AB 20I4/272 m.nt. P.J. Huisman en HR 6 februari 20I5, AB 2015/90 m.nt. F.J. van Ommeren (CAK).

I8 HR 4 april 2003, AB 2004/60 m.nt. G.A. van der Veen en HR I7 juni 20II, AB 20II/330 m.nt. F.J. van Ommeren (Van Sundert/Breda).

I9 Zie bijvoorbeeld HR I5 januari 1999, NJ I999/306 m.nt. A.R. Bloembergen, AB 2000/196 m.nt. Th.G. Drupsteen (Wrakkenwet II). I. Sluiter, 'De geldschuldenregeling: een warm onthaal door de bestuursrechter!', JBplus 20I2, p. 343 .

2I W. den Ouden e.a., De bestuursrechtelijke geldschuldenregeling, Titel 4.4. Awb geëvalueerd, Den Haag: WODC 2014, p. 53 (aangeboden bij Kamerstukken II 2013/I4, 29 279, nr. I94). 
bestuur ten aanzien van de invordering ook over de privaatrechtelijke bevoegdheden beschikt. ${ }^{22}$ De wetgever staat daarmee neutraal tegenover de uiteindelijke keuze van het bestuur voor de ene of de andere weg. Dit sluit overigens uiteraard niet uit dat de wetgever met een wettelijke voorziening in een specifiek geval juist een positieve voorkeur beoogt uit te spreken voor het gebruik van de privaatrechtelijke weg. Een voorbeeld van dit laatste biedt de anterieure grondexploitatie-overeenkomst van art. 6.24 Wet ruimtelijke ordening. ${ }^{23}$

\section{Eerste ijkpunt: inhoud en strekking van de regeling}

Bevat de publiekrechtelijke regeling geen antwoord op de vraag of de overheid gebruik mag maken van de privaatrechtelijke weg, dan komt de rechter in beginsel toe aan de doorkruisingsformule. Het ijkpunt 'inhoud en strekking van de regeling' biedt een instrument om te kunnen beoordelen of een publiekrechtelijke regeling in de weg staat aan het gebruik van het privaatrecht wanneer deze geen uitdrukkelijk antwoord bevat met betrekking tot de toelaatbaarheid van de privaatrechtelijke weg. De inhoud en strekking van een publiekrechtelijke regeling kunnen onder meer blijken uit de parlementaire geschiedenis daarvan. Soms betrekt de rechter, in zijn analyse, ook of de wetgever zich al dan niet heeft ingespannen om de bestaande praktijk van het gebruik van het privaatrecht door de overheid te beëindigen. ${ }^{24}$ De voorvraag en het eerste ijkpunt van de doorkruisingsformule liggen dicht tegen elkaar aan, de precieze grens tussen de twee is soms in concrete gevallen moeilijk aan te geven. Het onderscheidende criterium is of de wettekst expliciet het antwoord op de vraag bevat of het door de overheid hanteren van privaatrechtelijke bevoegdheden is toegestaan; staat het antwoord niet expliciet in de wet, dan komt de rechter toe aan toepassing van de ijkpunten van de doorkruisingsformule.

Het hier te noemen klassieke arrest is het Brandweerkosten-arrest (ook wel: Bluskosten Vlissingen). Het vergroot het inzicht als men dit arrest vergelijkt met een recent arrest dat eveneens betrekking heeft op het verhaal van door de overheid gemaakte kosten. Het overbekende Brandweerkosten-arrest heeft betrekking op het verhaal van de kosten van het blussen van een brand op een schip. Het op privaatrechtelijke leest geschoeide kostenverhaal werd niet toegestaan, omdat uit de parlementaire geschiedenis bleek dat de wetgever bewust geen voorziening voor kostenverhaal in het leven had geroepen, onder meer omdat hij vreesde dat daardoor een drempel voor de burger zou worden opgeworpen om tot alarmering over te gaan. Bovendien betrof het een kerntaak van de overheid, die van oudsher is uitgeoefend zonder dat kosten in rekening werden gebracht. De Hoge Raad leidde uit het ontbreken van een publiekrechtelijke voorziening af dat er evenmin plaats is

22 Bij de invordering kunnen publiek- en privaatrechtelijke bevoegdheden naast elkaar worden aangewend, tenzij hierop bij bijzondere wet uitzonderingen zijn gemaakt. Zie Kamerstukken II 2003/04, 29702 , nr. 3, p. 68-69.

23 Zie over deze overeenkomst: L.C. Groen, Het zelfrealisatierecht. Ruimtelijk instrumentarium in verhouding tot het eigendomsrecht (diss. Amsterdam VU), Den Haag: Stichting Instituut voor Bouwrecht 20I4, p. 36 I e.v.

24 HR 8 juni I99I, AB I99I/659 m.nt. F.H. van der Burg, NJ I99I/69I m.nt. M. Scheltema (Kunst- en Antiekstudio Lelystad). 
voor de privaatrechtelijke weg, aangezien de publiekrechtelijke regeling daardoor op onaanvaardbare wijze zou worden doorkruist. ${ }^{25}$

Het recente arrest heeft betrekking op het verhalen van kosten door de Staat voor het verwijderen van olie op de weg na een ongeval. ${ }^{26}$ Gelet op het Brandweerkostenarrest achtte de kantonrechter kostenverhaal door de overheid niet mogelijk, maar het hof wees de vordering alsnog toe. In het onderhavige geval werd een beroep gedaan op art. I lid 4 sub b Brandweerwet I985. ${ }^{27}$ Dit artikel verklaart mede tot de taak van de brandweer het beperken en bestrijden van gevaar voor mensen en dieren bij ongevallen anders dan bij brand. De Hoge Raad concludeert dat het hof terecht heeft geoordeeld dat, gelet op de parlementaire geschiedenis van de Brandweerwet 1985 , deze bepaling op acute gevaarsituaties ziet die veelal de snelle inschakeling van technische hulpmiddelen door de brandweer vereisen. Het verwijderen van olie na een ongeval valt daar niet onder, nu reeds met het afzetten van de weg het acute gevaar van die olie was verdwenen. De Hoge Raad merkt dan ook op dat het in casu niet gaat om kosten die door de brandweer zijn gemaakt uit hoofde van haar in de Brandweerwet 1985 omschreven taak, maar om kosten die de Staat heeft gemaakt uit hoofde van zijn taak als beheerder van de rijksweg. Het Brandweerkosten-arrest heeft slechts betrekking op eerstgenoemde kosten. Ook de Wegenwet laat zich niet expliciet uit over het verhaal van de hiervoor bedoelde schoonmaakkosten. Privaatrechtelijk kostenverhaal levert geen onaanvaardbare doorkruising op van deze wet, zo overweegt de Hoge Raad, aangezien dit verhaal publiekrechtelijk niet is uitgesloten. Dit is een belangrijk verschil met de strekking van de Brandweerwet I985. Uit een analyse van de parlementaire geschiedenis van de Wegenverkeerswet blijkt bovendien zelfs dat verhaal van deze kosten door de wetgever wenselijk wordt geacht.

Het verschil in uitkomst tussen het klassieke en het recente arrest illustreert helder het grote gewicht dat aan de parlementaire geschiedenis wordt toegekend. Bovendien is van belang dat het verhaal van de kosten van het verwijderen van olie op de weg geen betrekking heeft op kosten die door de brandweer zijn gemaakt uit hoofde van de uitoefening van haar in de wet omschreven taak. Dit verklaart waarom in het recente arrest het ontbreken van een publiekrechtelijke voorziening geen belemmering vormt voor kostenverhaal langs privaatrechtelijke weg, terwijl dat in het klassieke arrest juist wel het geval was.

Tweede ijkpunt: bescherming van de belangen van de burgers

In het kader van het tweede ijkpunt van de doorkruisingsformule kijkt de rechter naar de wijze waarop en de mate waarin in het kader van een publiekrechtelijke regeling de belangen van de burgers zijn beschermd. Voorziet het publiekrecht in verderstrekkende waarborgen, dan is dit een belangrijke aanwijzing dat het gebruik van het privaatrecht deze weg onaanvaardbaar doorkruist.

25 HR II december I992, AB I993/30I m.nt. G.A. van der Veen (Brandweerkosten).

26 HR I2 december 20I4, JB 20I5/I8 m.nt. L.J.M. Timmermans.

27 Dit artikel is inmiddels vervallen. In de Wet veiligheidsregio's is de inhoud van dit artikel overgenomen. Er is geen inhoudelijke wijziging van het geldende rechtsregime beoogd, zie Kamerstukken II 2006/07, 3I II7, nr. 3, p. 57. 
Bij dit ijkpunt gaat het er met name om welke materiële waarborgen de publiekrechtelijke regeling beoogt te geven en of er daarbij in bijzondere, extra waarborgen wordt voorzien ten opzichte van de privaatrechtelijke weg. Is dat het geval, dan leidt het gebruik van het privaatrecht in beginsel tot een onaanvaardbare doorkruising van het publiekrecht. Naast de materiële waarborgen valt te denken aan wettelijke procedurele waarborgen. Zo valt te wijzen op voorgeschreven inspraak-, overleg- en adviseringstrajecten waarin het publiekrecht kan hebben voorzien. Ook de wettelijke bestuurlijke bevoegdheidsverdeling mag niet op onaanvaardbare wijze worden doorkruist. Zo kan er gewicht worden toegekend aan het feit dat toestemming of goedkeuring van hogere bestuursorganen in een bestuursrechtelijk traject vereist kan zijn, terwijl dat in het alternatieve privaatrechtelijke traject niet nodig is. Is dit het geval, dan voorziet de publiekrechtelijke weg in meer waarborgen. ${ }^{28}$ Naar onze indruk is dit laatste aspect in de rechtspraak evenwel relatief weinig tot uitdrukking gekomen.

Het is een misverstand dat de bestuursrechtelijke rechtsbeschermingsmiddelen, meer in het bijzonder het maken van bezwaar en het instellen van beroep bij de bestuursrechter (zie art. 8:I jo. 7:I Awb), zodanige waarborgen voor de burger bieden dat de privaatrechtelijke weg reeds daarom onaanvaardbaar is. Dat neemt niet weg dat deze waarborgen wel een rol kunnen spelen bij het vormen van een oordeel of sprake is van een onaanvaardbare doorkruising. ${ }^{29}$

Er is een sterke relatie tussen het eerste en het tweede ijkpunt, aangezien de analyse van de bescherming van de belangen van de burger op grond van een publiekrechtelijke regeling voor een groot deel rust op een analyse van de inhoud en strekking daarvan. Het in beeld brengen van de wettelijk geboden waarborgen staat of valt immers met een analyse van inhoud en strekking van een regeling. Het wijzigen van de wet, door het toevoegen dan wel schrappen van extra waarborgen, kan gevolgen hebben voor de ruimte die de overheid heeft om de privaatrechtelijke weg in te zetten. ${ }^{30}$

Derde ijkpunt: vergelijkbaar resultaat

Voor het antwoord op de vraag of sprake is van een onaanvaardbare doorkruising kan voorts van belang zijn of de overheid door gebruikmaking van de publiekrechtelijke regeling een vergelijkbaar resultaat kan bereiken als door gebruikmaking van de privaatrechtelijke bevoegdheid, omdat, als dat het geval is, dit een belangrijke aanwijzing is dat geen plaats is voor de privaatrechtelijke weg. Om aan dit ijkpunt te kunnen toetsen moet een publiekrechtelijke weg mogelijk zijn. Het is niet vereist dat deze weg er daadwerkelijk is of wordt benut. Ontbreekt een publiekrechtelijke weg, dan valt uiteraard geen vergelijking te maken, hetgeen met zich brengt dat dit ijkpunt niet kan worden toegepast.

Hoewel dit ijkpunt als afzonderlijk punt in het Windmill-arrest wordt genoemd, lijkt de Hoge Raad daaraan - reeds bij de introductie van de doorkruisingsformule minder gewicht toe te kennen. Dit ijkpunt wordt als laatste genoemd en ingeleid

28 HR 9 juli I990, AB I990/547 m.nt. G.P. Kleijn, NJ I99I/394 m.nt. M. Scheltema (De Pina/Helmond).

29 Zie HR 2 mei 2003, AB 2003/354 m.nt. E.W.J. de Groot \& G.A. van der Veen (Nunspeet/Mulder), maar ook bijvoorbeeld het Windmill-arrest.

30 HR 7 mei 2004, AB 2004/247 m.nt. G.A. van der Veen (Heerde/Goudsmit). 
met de woorden 'van belang is voorts'. ${ }^{31}$ Dit zou de indruk kunnen wekken dat dit ijkpunt van weinig betekenis is. Op het terrein van de handhaving is dit ijkpunt echter juist vaak doorslaggevend. Standaardlijn in de jurisprudentie is dat als het bestuur de bevoegdheid heeft om een last onder dwangsom op te leggen, dit met zich brengt dat een privaatrechtelijke actie uit onrechtmatige daad - ter verkrijging van een met een dwangsom versterkt verbod - in beginsel een onaanvaardbare doorkruising oplevert van de betrokken publiekrechtelijke regeling. ${ }^{32}$

Betrekkelijk recent rees de vraag, onder meer in het arrest 'Luxemburgse bankrekening', ${ }^{33}$ of de inlichtingenplicht ex art. 47 Algemene wet inzake rijksbelastingen afgedwongen kan worden door middel van een civielrechtelijke dwangsom. Achtergrond van deze zaak was dat de Belastingdienst de nakoming wenste van deze wettelijke verplichting om meer inlichtingen te krijgen over de buitenlandse bankgegevens van een in Nederland belastingplichtige burger. De AWR voorzag niet in een publiekrechtelijke dwangsombevoegdheid, reden waarom de Belastingdienst naar de burgerlijke rechter stapte. Ontbreekt de mogelijkheid om een last onder dwangsom op te leggen, zoals in deze fiscaalrechtelijke setting het geval is, dan is het echter in beginsel wel mogelijk om aan de burgerlijke rechter te vragen een civielrechtelijke dwangsom op te leggen, zoals fraai door dit arrest wordt geïllustreerd. ${ }^{34} \mathrm{Wij}$ komen op de ruimte die er is om langs privaatrechtelijke weg te handhaven terug in paragraaf 2.6.

\section{Toepasselijkheid van alle ijkpunten?}

De rechter betrekt niet steeds alle ijkpunten in zijn overwegingen. Een voor de hand liggende verklaring hiervoor is, dat als bij één van de ijkpunten reeds blijkt dat sprake is van een onaanvaardbare doorkruising, het niet meer nodig is om verder te kijken naar de andere ijkpunten. ${ }^{35}$ Een andere verklaring is dat de rechter soms simpelweg niet kan toetsen aan een bepaald ijkpunt. Ontbreekt een publiekrechtelijke weg, dan kan de privaatrechtelijke weg daarmee niet vergeleken worden, het is dan niet mogelijk om te toetsen aan het ijkpunt 'vergelijkbaar resultaat'. ${ }^{36}$

Hiervan kan de situatie worden onderscheiden dat een casuspositie zich weliswaar leent voor toepassing van de doorkruisingsformule, maar de rechter deze formule niet dan wel niet expliciet toepast. In dit verband valt te wijzen op het Groenovereenkomsten-arrest. ${ }^{37}$ Het bij overeenkomst verhalen van kosten door de gemeente voor groenvoorzieningen was volgens de Hoge Raad niet toegestaan omdat uit het wettelijk stelsel - Wet op de Ruimtelijke Ordening (oud) en 
Gemeentewet - volgt dat het verhalen van deze kosten alleen mogelijk is wanneer daarvoor een wettelijke grondslag bestaat. Vanuit het oogpunt van rechtszekerheid, zo wordt daaraan toegevoegd, is een dergelijke grondslag mede wenselijk. Strikt genomen past de Hoge Raad de doorkruisingsformule niet toe, maar zijn in de overwegingen (ook) de eerste twee ijkpunten te herkennen ('inhoud en strekking van de regeling' en 'de wijze waarop en de mate waarin in het kader van de regeling de belangen van de burger zijn beschermd'). Dit werpt de vraag op hoe de formule zich verhoudt tot andere maatstaven zoals strijd met de wet en het legaliteitsbeginsel (zie ter zake nader paragrafen 2.4 e.v.).

\section{De doorkruisingsformule gewogen}

De doorkruisingsformule is in de doctrine aan kritiek onderhevig, waarbij het algemene punt van kritiek is dat de voorspellende waarde van deze formule (te) beperkt is. ${ }^{8}$ De kanttekeningen spitsten zich vervolgens concreet toe op de ijkpunten 'inhoud en strekking van de publiekrechtelijke regeling' en 'vergelijkbaar resultaat'.

Als zwakte van het ijkpunt 'inhoud en strekking van de regeling' wordt gezien dat de precieze bedoeling van de wetgever vaak onduidelijk is. ${ }^{39}$ In de meeste gevallen heeft de wetgever zich niet uitgelaten over het gebruik van het privaatrecht. Het komt derhalve uiteindelijk aan op een interpretatie door de rechter van een - gededuceerde - bedoeling van de wetgever in het verleden, hetgeen tot de vraag leidt in hoeverre aan deze bedoeling (nog) waarde kan en mag worden gehecht, aangezien deze bedoeling verouderd of inmiddels bijgesteld kan zijn.

De kritiek op het ijkpunt van het 'vergelijkbaar resultaat' is dat het resultaat dat via de publiekrechtelijke weg te bereiken is, in de meeste gevallen niet vergelijkbaar is met het resultaat dat via het privaatrecht bereikt kan worden, in die zin dat met gebruikmaking van de privaatrechtelijke weg door de overheid vaak 'betere' resultaten kunnen worden geboekt ter verwezenlijking van het overheidsbeleid. $4^{\circ}$ Het privaatrecht wordt juist vanwege haar karakteristieken - zoals flexibiliteit en (vorm)vrijheid - ingezet om efficiëntere en effectievere resultaten te bereiken. Een vergelijking op het punt van het resultaat heeft, zo opgevat, nauwelijks toegevoegde waarde ten opzichte van de andere ijkpunten. Mogelijk dat dit ijkpunt daarom spaarzaam en eigenlijk alleen op het terrein van handhaving betekenis heeft gekregen.

Het ijkpunt van het 'vergelijkbaar resultaat' wordt daarnaast als weinig onderscheidend of onduidelijk gezien omdat het niet eenduidig toegepast zou worden. In handhavingssituaties wordt uit de beschikbaarheid van een publiekrechtelijke bevoegdheid afgeleid dat het gebruik van het privaatrecht niet is toegestaan. Uit het Brandweerkosten-arrest wordt daarentegen in de literatuur afgeleid dat het ontbreken van een publiekrechtelijke weg, en daarmee het ontbreken van een vergelijkbaar resultaat, ertoe kan leiden dat de privaatrechtelijke weg niet is toegestaan.

38 Zie bijvoorbeeld J.E.M. Polak, Burgerlijke rechter of bestuursrechter? De gewenste verdeling van rechtsmacht bij: regelgeving, schadeveroorzakend overheidshandelen, tweewegenleer-vragen (diss. Amsterdam UvA), Deventer: Kluwer i999, p. I08 e.v.

39 Polak 1999, p. I08 en Schlössels \& Zijlstra 20I0, p. 528.

40 Polak I999, p. II2 en Schlössels \& Zijlstra 20I0, p. 528. 
Het wordt problematisch geacht dat het ijkpunt zo bezien verschillend en niet consistent wordt toegepast. ${ }^{4 \mathrm{I}}$

Het valt op dat het ijkpunt van de 'bescherming van de belangen van de burger' veel minder wordt bekritiseerd. Naar het zich laat aanzien komt dat doordat juist dit ijkpunt goed aansluit bij de premisse die aan de gehele formule ten grondslag ligt: de bescherming van publiekrechtelijke waarborgen (er zij aan herinnerd dat reeds uit het Windmill-arrest blijkt dat de doorkruisingsformule aan de orde is voor de beoordeling van de toelaatbaarheid van de privaatrechtelijke weg indien aan de overheid voor de behartiging van bepaalde belangen publiekrechtelijke bevoegdheden zijn toegekend). Bovendien zit, nu het ijkpunt van het 'vergelijkbaar resultaat' in de rechtspraak veel minder uit de verf is gekomen, juist hier de meeste toegevoegde waarde ten opzichte van de situatie van voor het Windmill-arrest.

De kritiek op de doorkruisingsformule is herkenbaar, maar doet naar onze mening geen afbreuk aan de betekenis ervan, zoals die zich de afgelopen decennia in de rechtspraak heeft geopenbaard. De kritiek is in belangrijke mate te relativeren door de formule te beschouwen als een algemene maatstaf om achteraf, in situaties waarin bij uitstek onduidelijk is of privaatrechtelijk overheidshandelen is toegestaan, te beoordelen in hoeverre in een concreet geval daadwerkelijk ruimte voor de overheid is om de privaatrechtelijke weg te kiezen. Het aantrekkelijke van deze algemene formule is dat zij te gebruiken is als een hulpmiddel waarmee door de toepassing stap voor stap standaardsituaties kunnen worden herkend. Dat zorgt voor de broodnodige rechtszekerheid, waar de praktijk goed mee uit de voeten kan. Zo is het thans helder dat kosten gemaakt door de brandweer voor het blussen van een brand niet via het privaatrecht kunnen worden verhaald. Ook is het duidelijk dat als het via een last onder dwangsom of bestuursdwang mogelijk is te handhaven, privaatrechtelijke handhaving niet tot de mogelijkheden behoort. Op deze standaardsituaties kan vervolgens worden voortgebouwd en kunnen nuanceringen worden aangebracht. Zo kunnen andere kosten die niet behoren tot de wettelijke kerntaak van de brandweer wel worden verhaald. Bestaat er geen mogelijkheid om een bestuursrechtelijke dwangsom op te leggen, dan kan met succes via de burgerlijke rechter een dwangsom worden gevorderd. Daar komt bij dat de rechter uiteindelijk niet het laatste woord heeft. Indien nodig, is het aan de wetgever om de handschoen op te pakken en bepaald handelen alsnog toe te staan of te verbieden, hetgeen in de praktijk ook daadwerkelijk is gebeurd. ${ }^{42} \mathrm{Het}$ is juist door de stapsgewijze ontwikkeling van dit soort standaardsituaties dat de doorkruisingsformule een waardevolle bijdrage heeft geleverd en nog steeds levert aan de beantwoording van de vraag of de overheid de ruimte heeft voor de privaatrechtelijke weg. Alles bij elkaar genomen is de doorkruisingsformule dan ook een uiterst belangrijke maatstaf, zij het dat zij niet de enige is.

4I Zie bijvoorbeeld Polak I999, p. II2 en Scheltema \& Scheltema 20I3, p. 453.

42 Zie HR 8 juni I99I, AB I99I/659 m.nt. F.H. van der Burg, NJ I99I/69I m.nt. M. Scheltema (Kunst-en Antiekstudio Lelystad) en HR 2 mei 2003, AB 2003/354 m.nt. E.W.J. de Groot \& G.A. van der Veen, NJ 2003/485 m.nt. P.C.E. van Wijmen (Nunspeet/Mulder) waarin de Hoge Raad uitdrukkelijk overweegt dat het aan de wetgever is om te handelen. Naar aanleiding van het arrest Nunspeet/Mulder heeft de wetgever ook daadwerkelijk een voorziening getroffen. 


\subsection{Andere maatstaven}

Voor de beantwoording van de vraag of privaatrechtelijk overheidshandelen is toegestaan, zijn naast de doorkruisingsformule ook andere maatstaven relevant. Op de belangrijkste andere maatstaven die in de rechtspraak worden gehanteerd, gaan wij nu in.

Strijd met de wet: evidente inhoudelijke strijd met de wet

In bepaalde gevallen komt de rechter, ook in situaties waarin de wetgever niet expliciet in de wettekst heeft bepaald of privaatrechtelijk overheidshandelen is toegestaan, aan de doorkruisingsformule niet toe. Dit doet zich bijvoorbeeld voor als, ofschoon publiekrechtelijke bevoegdheden zijn toegekend, het hanteren van het privaatrecht door de overheid qua inhoud evident in strijd is met de wet. ${ }^{43}$ Hieraan wordt in de regel de consequentie verbonden dat de privaatrechtelijke rechtshandeling nietig is (art. 3:40 lid I BW). ${ }^{44} \mathrm{Er}$ is dan geen behoefte aan de doorkruisingsformule. Dit is vergelijkbaar met situaties waarin de zaak wordt afgedaan op grond van de 'voorvraag' zoals te vinden in het Windmill-arrest.

\section{Strijd met de wet: het legaliteitsbeginsel}

Het komt voor dat de rechter zijn overwegingen niet (expliciet) giet in een toetsing aan de doorkruisingsformule, terwijl dat wel had gekund, maar in plaats daarvan een redenering bezigt aan de hand van het legaliteitsbeginsel. Het arrest Staat/Lenger is hiervoor illustratief. ${ }^{45}$ In deze zaak had Lenger een onjuiste voorlopige aangifte gedaan. Op grond van de Algemene wet inzake rijksbelastingen was het niet mogelijk om heffingsrente in rekening te brengen. De vraag was of de Staat via een onrechtmatigedaadsactie bij de burgerlijke rechter wel de gederfde rente kon verhalen. De Hoge Raad plaatst zijn overwegingen in de sleutel van het legaliteitsbeginsel: het heffen van een rijksbelasting en wat daarbij hoort - zoals het in rekening brengen van heffingsrente - is alleen toegestaan als daarvoor een wettelijke grondslag is (zie art. Io4 Grondwet). Uit de wetsgeschiedenis volgt dat de wetgever ervan uitgaat dat de regeling in de AWR, voor zover in deze zaak van belang, zich niet leent voor aanvulling door de gewone rechter met privaatrechtelijke instrumenten. Het vorderen van de gederfde rente bij de burgerlijke rechter door de Staat behoort daarom niet tot de mogelijkheden. De Hoge Raad acht dit (het vorderen van deze heffingsrente) in strijd met het fiscaalrechtelijk legaliteitsbeginsel, omdat de

43 HR 7 april 2000, AB 2000/438 m.nt. Th.G. Drupsteen (Parkeerexploitatie Amsterdam BV).

44 Art. 3:40 lid 2 BW komt hier - alhoewel daarover in de bestuursrechtelijke literatuur soms, ten onrechte, anders over wordt gedacht - niet in beeld. Dit artikellid ziet er alleen op dat de wet expliciet het verrichten van de privaatrechtelijke rechtshandeling verbiedt. Is niet het verrichten verboden bij wet maar komt de privaatrechtelijke handeling inhoudelijk in strijd met de wet, dan wordt de nietigheid gebaseerd op het eerste lid van art. 3:40 BW. Zie TM, PG Boek 3 BW, p. I9I en MvA II, PG Boek 3 BW, p. I92. Zie ook A.S. Hartkamp \& C.H. Sieburgh, Mr. C. Assers handleiding tot de beoefening van het Nederlands Burgerlijk Recht. Verbintenissenrecht. Deel III. Algemeen overeenkomstenrecht, Deventer: Kluwer 20I4, nrs. 317 en 325 .

45 HR 8 mei I998, AB I998/390 m.nt. Th.G. Drupsteen (Staat/Lenger). Zie ook HR 8 oktober I993, AB I994/299 m.nt. F.H. van der Burg (Marken). 
toepasselijke publiekrechtelijke regeling (de AWR) niet voorziet in een grondslag voor het in rekening brengen van de gederfde rente. Het was evenwel ook mogelijk geweest om te redeneren langs de lijn van het ijkpunt 'inhoud en strekking' van de doorkruisingsformule.

Het voorgaande doet de vraag rijzen hoe de relatie tussen de tweewegenleer met de doorkruisingsformule en het legaliteitsbeginsel moet worden opgevat. Zoals het legaliteitsbeginsel betrekking heeft op de bevoegdheid om publiekrechtelijk te handelen, zo heeft de tweewegenleer betrekking op de bevoegdheid om privaatrechtelijk op te treden. Toch gaat het legaliteitsbeginsel in wezen aan de tweewegenleer vooraf. Bij de toepassing van de tweewegenleer dient immers eerst te worden vastgesteld of en in hoeverre de overheid de bevoegdheid heeft om publiekrechtelijk op te treden. ${ }^{6}{ }^{6}$

\section{Misbruik van een privaatrechtelijke bevoegdheid}

In de oude rechtspraak over de tweewegenleer van vóór Windmill nam het misbruikcriterium een vrij prominente plaats in, ofschoon het niet vlug tot de conclusie leidde dat de privaatrechtelijke weg niet toelaatbaar was. ${ }^{47}$ Met de introductie van de doorkruisingsformule leek het naar de achtergrond verdwenen, maar sinds enkele jaren duikt deze maatstaf opnieuw op in de rechtspraak van de Hoge Raad. Hij geeft er daarbij wel een andere wending aan dan in zijn oude rechtspraak.

De Hoge Raad heeft namelijk enige jaren geleden in het arrest Amsterdam/Geschiere een nadere uitwerking aan de tweewegenleer gegeven. ${ }^{4}$ Onder omstandigheden kan het gebruik van het privaatrecht misbruik van bevoegdheid opleveren in de zin van art. 3:13 BW. Dit misbruikleerstuk komt met name in beeld wanneer privaatrechtelijke toestemming (bijvoorbeeld toestemming van de gemeente als eigenaar van een perceel grond) vereist is naast of in aanvulling op een publiekrechtelijke toestemming (bijvoorbeeld een vergunning of ontheffing). Het is in dit soort gevallen de vraag of en onder welke omstandigheden het mogelijk is om de privaatrechtelijke toestemming te weigeren.

In het arrest Amsterdam/Geschiere wijdt de Hoge Raad hieraan de volgende algemene overweging:

'Nu de Gemeente aan Geschiere een publiekrechtelijke vergunning heeft verleend tot het innemen van een staanplaats op de locatie waarvan de Gemeente eigenaar is, heeft zij bij de uitoefening van haar bevoegdheid als eigenaar van de desbetreffende grond tot het al of niet verlenen van privaatrechtelijke toestemming, tot uitgangspunt te nemen dat Geschiere door de verlening van de vergunning is gerechtigd tot het gebruik van de locatie overeenkomstig de vergunning. Daarom levert een weigering door de Gemeente van die toestemming aan Geschiere voor het door hem beoogde gebruik van de locatie overeenkomstig de vergunning, misbruik van bevoegdheid op, tenzij sprake is van zo zwaarwegende belangen die zich verzetten tegen dat gebruik, dat niet gezegd kan

Zie F.J. van Ommeren, 'Legaliteitsbeginsel en tweewegenleer', NTBR I999, p. 26 e.v.

47 Zie bijv. HR I3 april I962, ARB I962, p. 487 m.nt. J.R. Stellinga, AB Klassiek 2003/9 m.nt. D.A. Lubach (Kruseman).

48 HR 5 juni 2009, AB 2009/327 m.nt. G.A. van der Veen, Gst. 2009 (7324), nr. 98 m.nt. J.A.E. van der Does \& P.J. Huisman, JB 2009/I7I m.nt. J.A.F. Peters (Amsterdam/Geschiere). 
worden dat de Gemeente wegens onevenredigheid tussen haar belang bij weigering en het belang van Geschiere, niet tot die weigering heeft kunnen komen.' 49

De Hoge Raad neemt hier tot uitgangspunt dat de vergunning in beginsel de vergunninghouder gerechtigd maakt tot gebruik ervan en dat weigering van de privaatrechtelijke toestemming door de overheid misbruik van bevoegdheid oplevert. De Hoge Raad laat uitdrukkelijk ruimte voor een uitzondering, namelijk wanneer sprake is van zwaarwegende belangen aan de zijde van de overheid. De vraag is uiteraard wanneer van zo zwaarwegende belangen sprake is en hoe dat moet worden vastgesteld. Het blijkt dat met name moet worden gelet op het soort belang dat daarvoor wordt aangevoerd én of en in hoeverre dit belang reeds een rol heeft gespeeld bij de publiekrechtelijke belangenafweging. De zaak Amsterdam/Geschiere is hiervoor illustratief.

Aan Geschiere was een vergunning verleend tot het innemen van een staanplaats. De gemeente had in casu twee verschillende argumenten aangevoerd waarom zij weigerde de bovendien benodigde privaatrechtelijke toestemming te verlenen: zij had belang bij voldoende beschikbare parkeerplaatsen in het desbetreffende gebied en voorts had zij het voornemen de grond in de nabije toekomst in erfpacht te gaan uitgeven. Wat betreft het gemeentelijke belang op het behoud van voldoende parkeerruimte overwoog de Hoge Raad dat deze belangen al voldoende in het kader van de publiekrechtelijke vergunningverlening op voet van de toepasselijke verordening zijn meegewogen. Ten aanzien van het gemeentelijke belang op onbelemmerde erfpacht in de toekomst overwoog de Hoge Raad dat dit niet een belang is waarop de toepasselijke regeling betrekking heeft; derhalve kan in de ogen van de Hoge Raad van een doorkruising, laat staan een onaanvaardbare doorkruising, van die regeling geen sprake zijn. Of het weigeren van privaatrechtelijke toestemming is toegestaan, is derhalve afhankelijk van het soort belang dat aan de weigering ten grondslag ligt.

Uit dit arrest volgt dat het publiekrechtelijke toetsingskader in de ogen van de Hoge Raad het primaat heeft. Het is immers dit toetsingskader dat bepalend is voor de ruimte die overblijft voor de privaatrechtelijke belangenafweging. In het oog springt dat het privaatrechtelijke belang langs deze afwegingsroute relatief weinig gewicht in de schaal legt. Met andere woorden: de publiekrechtelijke belangenafweging is dominant.

De vraag rijst uiteraard hoe dit misbruikcriterium zich verhoudt tot de doorkruisingsmaatstaf. Een coherente uitleg van de doorkruisingsrechtspraak en het arrest Amsterdam/Geschiere, met zijn accent op de aard van de af te wegen belangen, brengt met zich dat de vraag of de publiekrechtelijke regeling op onaanvaardbare wijze wordt doorkruist, aan de orde is voor zover de overheid 'bij een publiekrechtelijke regeling ter behartiging van zekere belangen bepaalde bevoegdheden zijn toegekend' (Windmill). Voor zover dat niet het geval is, is het misbruikcriterium van toepassing. ${ }^{50}$ De vraag waarop verder in de rechtspraak stapsgewijs een antwoord

49 HR 5 juni 2009, AB 2009/327 m.nt. G.A. van der Veen, Gst. 2009 (7324), nr. 98 m.nt. J.A.E. van der Does \& P.J. Huisman, JB 2009/I7I m.nt. J.A.F. Peters (Amsterdam/Geschiere), r.o. 3.4.I.

50 G.T.J.M. Jurgens, 'Onaanvaardbare doorkruising of misbruik van bevoegdheid? Een systematische benadering van de verhouding tussen publiekrechtelijk en privaatrechtelijk overheidshandelen', Overheid en Aansprakelijkheid 20II, p. 84 e.v. 
moet worden gezocht, is welke privaatrechtelijke belangen (d.w.z. belangen waarvan de afweging niet al in de publiekrechtelijke regeling zijn verdisconteerd) zo zwaar wegen dat de privaatrechtelijke weigering geen misbruik van bevoegdheid oplevert. Meer specifiek is de vraag in hoeverre een financiële vergoeding mag worden gevraagd voor de privaatrechtelijke toestemming. Die vraag komt aan de orde in paragraaf 4.2 .

\section{Grondrechten en algemene beginselen van behoorlijk bestuur}

Wanneer het de overheid in principe toegestaan is de privaatrechtelijke weg te bewandelen, brengt dit met zich dat op die privaatrechtelijke rechtsverhouding normen van publiekrechtelijke herkomst van toepassing zijn, zoals de grondrechten en de algemene beginselen van behoorlijk bestuur. Het gaat dan niet meer zozeer om de vraag of en in hoeverre er ruimte is voor gebruikmaking van privaatrechtelijke bevoegdheden (de tweewegenvraag), maar om de vervolgvraag of die bevoegdheden rechtens aldus correct worden gebruikt (de vraag naar het toepasselijke recht). De grens tussen deze twee vragen is soms echter wat diffuus.

Het kan gaan om situaties waarin het privaatrechtelijk overheidshandelen op zichzelf geen onaanvaardbare doorkruising oplevert, maar waarin de grondrechten en algemene beginselen van behoorlijk bestuur extra algemene waarborgen bieden voor burgers. Het kan echter ook voorkomen dat een bepaalde situatie had kunnen worden getoetst aan de doorkruisingsformule, maar dat de rechter kiest voor de toetsing aan de hand van de algemene beginselen van behoorlijk bestuur. In dit verband valt te wijzen op het arrest Alkemade/Hornkamp, waarin het ging om een contract waarin de gemeente had afgesproken een planologische bevoegdheid op een bepaalde manier te zullen uitoefenen. ${ }^{51}$ De Hoge Raad oordeelt dat de verplichting die de overheid van de wederpartij bedingt een koppeling moet hebben met het doel van de publiekrechtelijke bevoegdheid waarover de overheid contracteert. Dit doel volgt uit het wettelijk kader; treedt de privaatrechtelijk handelende overheid buiten dit doel, dan is sprake van strijd met het verbod van détournement de pouvoir (art. 3:3 Awb). Het was goed mogelijk geweest om via het ijkpunt 'inhoud en strekking van de regeling' te betogen dat hier sprake was van een onaanvaardbare doorkruising van de Wet op de Ruimtelijke Ordening. Toch doet de Hoge Raad dit niet. Mogelijk dat dit is ingegeven door het feit dat sprake is van een contract over een publiekrechtelijke bevoegdheid (een zogeheten bevoegdhedenovereenkomst); we gaan hierop in hoofdstuk 4 dieper in.

\subsection{Bevoegdheidstoekenning aan privaatrechtelijke overheidsrechtspersonen}

De doorkruisingsformule heeft een ruime reikwijdte, doordat zij in beginsel van toepassing is op alle aan de overheid krachtens het privaatrecht toekomende bevoegdheden. Op grond van de jurisprudentie wordt de doorkruisingsformule ook toegepast op de bevoegdheid om privaatrechtelijke rechtspersonen op te richten en

5I HR 3 april I998, AB I998/24I m.nt. Th.G. Drupsteen, NJ I998/588 m.nt. A.R. Bloembergen (Alkemade/Hornkamp). 
daaraan bevoegdheden toe te kennen. Het is echter de vraag hoe dit criterium zich verhoudt tot een meer publiekrechtelijke benadering die op het legaliteitsbeginsel is gebaseerd. Dit is te illustreren aan de hand van het arrest SKV-III. ${ }^{52}$

De zaak SKV-III draaide om de Stichting Kwaliteitsgarantie Vleeskalversector (SKV). Deze stichting is in het leven geroepen door een tweetal productschappen. De stichting fungeert als een door de rechter aangeduide 'verlengde arm' van deze productschappen bij het tot stand brengen en toepassen van een systeem van privaatrechtelijke controle en sancties met het oog op handhaving van een aantal publiekrechtelijke verboden. Van belang is dat, hoewel er geen juridische verplichting was voor kalvermesters om zich via een (civielrechtelijke) overeenkomst aan te sluiten bij SKV en zich daardoor te onderwerpen aan dit privaatrechtelijke systeem van handhaving, vrijwel alle betrokkenen zich daarbij aangesloten hebben; nietaansluiting zou namelijk kunnen leiden tot een verzwakte marktpositie. ${ }^{53}$ De vraag is of het de productschappen vrijstond om SKV aldus bij de handhaving in te zetten. De Hoge Raad overweegt uitdrukkelijk dat deze vraag moet worden beantwoord aan de hand van de maatstaven van het Windmill-arrest. Hij komt tot de slotsom dat zulks leidt tot een onaanvaardbare doorkruising van het publiekrechtelijke regelgevings- en handhavingssysteem dat de wetgever blijkens het bepaalde in art. 5 WED en onder meer art. 95 lid 2 Wet op de bedrijfsorganisatie (oud) voor ogen heeft gestaan. In zijn overwegingen zijn het eerste en het tweede ijkpunt van de doorkruisingsformule goed te herkennen. In het bijzonder overweegt hij dat langs deze weg de waarborgen van art. 95 lid 2 Wet op de bedrijfsorganisatie (oud) worden ondergraven. Dit artikellid stond eraan in de weg dat het bestuur van een bedrijfslichaam zijn bevoegdheden overdraagt aan een ander orgaan dan dat van het bedrijfslichaam. ${ }^{54}$

In de literatuur is wel het standpunt ingenomen dat op deze kwestie de doorkruisingsformule niet had mogen worden toegepast, aangezien de stichting en de betrokken productschappen verschillende rechtssubjecten zijn. ${ }^{55}$ Deze kritiek achten wij te formalistisch van aard, aangezien de stichting onmiskenbaar nauwe banden met de productschappen had en het bovendien inherent is aan de uitbesteding van overheidstaken dat daarbij verschillende rechtssubjecten aan de orde zijn. Dit neemt niet weg dat ook in onze ogen de vraag rijst of een andere benadering niet evenzeer denkbaar was geweest.

Het publiekrecht kent immers algemene regels voor de toekenning van publiekrechtelijke bevoegdheden en de overdracht daarvan. Zo bevat titel Io.I Awb algemene regels over mandaat, delegatie en attributie. Voor overdracht van bestuurs-

52 HR 20 december 2002, AB 2003/344 m.nt. F.J. van Ommeren (SKV-III).

53 Zie over (gedwongen) aansluiten: A.A. Freriks, 'Private handhaving - bestuursrechtelijke betekenis van (semi)private figuren in de handhaving van publieke normstelling’, in: S.E. Zijlstra, R.A.J. van Gestel en A.A. Freriks, Privaat bestuur? (VAR preadviezen 2008), Den Haag: Boom Juridische uitgevers 2008, p. 200-204.

54 In de eerdere arresten SKV-I en -II (HR 28 februari I997, AB I997/3I4 m.nt. Th.G. Drupsteen (SKVI), HR Io december I999, NJ 2000/8 (SKV-II)) was sprake van de handhaving van verboden handelingen die zijn aan te merken als 'economische delicten' in de zin van art. 5 Wet op de economische delicten (te weten de constatering van verboden stoffen), dat was in SKV-III niet het geval (het betrof i.c. het afleveren van kalveren zonder geldig certificaat).

55 J.A.F. Peters in zijn noot onder SKV-III, JB 2003/32 en J.A.F. Peters, 'Zelfregulering en rechter', JBplus 2007, p. 198. 
bevoegdheden bepaalt art. IO:I5 Awb dat dit slechts kan plaatsvinden als daar een uitdrukkelijke wettelijke grondslag voor is. Art. 95 lid 2 Wet op de bedrijfsorganisatie (oud) biedt zo'n grondslag, maar bevat de beperking dat alleen aan andere bestuursorganen binnen het productschap mag worden gedelegeerd. Hiervan mag niet bij verordening van het productschap worden afgeweken. ${ }^{56}$ Uit dit voorschrift volgt reeds dat een overdracht aan een ander orgaan dan een orgaan van het bedrijfslichaam niet is toegestaan. In de situatie van het arrest SKV-III, oefent SKV in plaats van het bestuur van het Productschap Vee en Vlees bepaalde handhavingsbevoegdheden uit. Op grond van deze benadering zou men het standpunt kunnen huldigen dat de overdracht aan een stichting niet is toegestaan. $\mathrm{Nu}$ is daar wel iets tegenover te stellen, want in casu was er immers slechts sprake van schijn- of pseudodelegatie (formeel lagen de bevoegdheden immers nog steeds bij het bestuur van het productschap), maar de facto komt de gehanteerde constructie wel neer op (verboden) delegatie.

Het is onzes inziens dan ook goed verdedigbaar om te stellen dat uit de toepasselijke publiekrechtelijke regels (art. I0:I5 Awb jo. art. 95 lid 2 Wet op de bedrijfsorganisatie (oud)) reeds volgde dat deze constructie niet was toegestaan. Aldus wordt door de schijndelegatie heen geprikt. De vraag of publiekrechtelijke bevoegdheden kunnen worden overgedragen, is derhalve een vraag die via de lijnen van het legaliteitsbeginsel eveneens kan worden beantwoord. Aan de doorkruisingsformule behoeft dan niet meer te worden toegekomen.

Niet alleen bij dit soort 'privatiseringen', maar ook bij bepaalde soorten overheidsovereenkomsten speelt de vraag of een publiekrechtelijke benadering de voorkeur heeft boven het hanteren van de doorkruisingsformule (zie hierover uitvoeriger hoofdstuk 4).

\subsection{Handhaving langs privaatrechtelijke weg?}

Sinds hij de doorkruisingsformule is gaan toepassen, heeft de Hoge Raad de ruimte voor de overheid aanzienlijk ingeperkt om langs privaatrechtelijke weg tegen de overtreding van publiekrechtelijke wettelijke voorschriften op te treden. Wanneer is voorzien in de bevoegdheid om een last onder dwangsom op te leggen, dan is er - vanwege het vergelijkbare resultaat dat daarmee kan worden bereikt - naar geldend recht geen ruimte voor handhaving via de privaatrechtelijke weg, zo bleek reeds. ${ }^{57}$

Toch zijn er verschillende gevallen waarin het bestuur niettemin behoefte kan hebben aan de privaatrechtelijke handhavingsroute. Dit heeft voor een belangrijk deel te maken met de risico's die voor het bestuur kunnen kleven aan het gebruik van het bestuursrechtelijke handhavingsinstrumentarium, zoals het opleggen van een last onder bestuursdwang of een last onder dwangsom: te denken valt aan de (al dan niet terechte) zorg voor slepende gerechtelijke procedures en forse schadeclaims achteraf.

56 Delegatie van bevoegdheden van organen van lagere overheden, zoals productschappen, is alleen toegestaan aan organen die bij wet in formele zin als adressaat zijn aangewezen. Het betreft het zogenoemde 'gesloten stelsel' van bevoegdheidsverkrijging van lagere overheden. Daarover nader S.E. Zijlstra, Bestuurlijk organisatierecht, Deventer: Kluwer 2009, p. 34.

57 Zie paragraaf 2.3 onder verwijzing naar HR 22 oktober 1993, AB I994/I m.nt. G.A. van der Veen (Staat/Magnus) en HR 7 oktober I994, AB I995/47 (Zomerhuisje). 
Terwijl het bestuursorgaan het bestuursrechtelijke handhavingsinstrumentarium, wanneer dat aan de orde is, in beginsel direct kan inzetten zonder tussenkomst van de rechter, is het eigen aan de handhaving langs privaatrechtelijke weg dat de overheid daarvoor een actie moet instellen bij de rechter. Dat kán bezwaarlijk zijn: niet voor niets is het bestuursrechtelijke handhavingsinstrumentarium de afgelopen jaren nu juist zo in den brede versterkt om het bestuur snel en zonder omwegen de mogelijkheid te geven om handhavend op te treden. Maar een preventieve rechterlijke toets kan ook aantrekkelijk worden geacht: het bestuur heeft dan vooraf de zekerheid dat het handhavende optreden rechtens geoorloofd is.

Een andere reden waarom de privaatrechtelijke handhavingsroute voor het bestuur aantrekkelijk kan zijn, is dat langs deze weg wellicht meer mogelijkheden bestaan om preventief tegen een overtreding op te treden. De wettelijke eisen voor de bevoegdheid tot het preventief opleggen van bestuursrechtelijke sancties zijn tamelijk streng. Ingevolge art. 5:7 Awb kan een herstelsanctie slechts worden opgelegd zodra het gevaar voor de overtreding klaarblijkelijk dreigt. Onzes inziens is er niet zoveel op tegen dat de rechter - juist omdat hij vooraf kan toetsen en (uiteraard) geen eigen belangen heeft - hier ruimhartiger kan zijn dan een bestuursorgaan. Dat betekent dat hij eerder preventief een verbod op straffe van een dwangsom kan geven dan dat het bestuursorgaan preventief een sanctie kan opleggen. Voorts kan er behoefte zijn aan handhaving via privaatrechtelijke weg jegens buitenlandse overtreders jegens wie een verbeurde bestuursrechtelijke dwangsom niet ten uitvoer kan worden gelegd. Niet geheel uitgesloten is overigens dat in deze gevallen ook naar geldend recht nog steeds de privaatrechtelijke weg kan worden gevolgd..$^{8}$

Is, op de keper beschouwd, het volgen van de privaatrechtelijke handhavingsweg eigenlijk wel zo bezwaarlijk? De waarborgen van de burger raken daardoor niet (nog) meer onder druk dan als bestuursrechtelijk wordt gehandhaafd. Sterker nog, door een preventieve toets door een onafhankelijke en onpartijdige derde - de rechter - nemen die waarborgen juist toe! Het is van belang dit in het oog te houden, omdat de ratio van de tweewegenleer met de doorkruisingsformule nu juist is, zo bleek, om belemmering van de behartiging van de belangen waarvoor het bestuursorgaan publiekrechtelijke bevoegdheden zijn toegekend, te voorkomen. Het is onzes inziens dan ook zeer de vraag of het afsnijden van de privaatrechtelijke weg hier wel zo wenselijk is. Ligt het niet veel meer in de rede om het bestuur de keuzeruimte te bieden tussen de publiekrechtelijke en privaatrechtelijke handhavingsweg? Het kan dan zelf afwegen of het behoefte heeft aan een preventieve rechterlijke toets of dat het het aandurft om direct (bestuursrechtelijk) te gaan handhaven. Daarbij kan het zelf een risicoanalyse maken en op grond daarvan een keuze maken.

58 Zie: G.T.J.M. Jurgens, A.P.W. Duijkersloot \& R.J.G.M. Widdershoven, 'Raakvlakken tussen bestuursrecht en privaatrecht op het terrein van de handhaving', in: E.F.D. Engelhard e.a. (red.), Handhaving van en door het privaatrecht, Den Haag: Boom Juridische uitgevers 2009, p. I2I e.v.; A.P.W. Duijkersloot e.a., De doorkruisingsleer in perspectief, Den Haag: VNG-uitgave 20I0, p. 74, P.J.J. van Buuren, G.T.J.M. Jurgens \& F.C.M.A. Michiels, Bestuursdwang en dwangsom (Mastermonografieën Staats- en bestuursrecht), Deventer: Kluwer 20I4, p. 33 en G.T.J.M. Jurgens \& F.C.M.A. Michiels, 'De burgerlijke rechter en de handhaving van het publiekrecht', in: R.J.N. Schlössels e.a. (red.), De burgerlijke rechter in het publiekrecht, Deventer: Wolters Kluwer 20I5, n.n.g. 
Het valt te betwijfelen of de doorkruisingsformule hier wel de meest geschikte maatstaf is om de ruimte voor deze privaatrechtelijke weg te beoordelen. Zo is het nog maar zeer de vraag of het ijkpunt van het vergelijkbaar resultaat hier een goed criterium biedt: er kunnen immers goede redenen zijn om reeds vanwege de rechterlijke tussenkomst de privaatrechtelijke weg aantrekkelijker te achten. Het ijkpunt van de bescherming van de belangen van de burger zal, naar het ons voorkomt, niet vlug een drempel kunnen opwerpen voor de privaatrechtelijke weg: door de tussenkomst van de rechter zijn de belangen van de betrokkenen eerder meer dan minder gewaarborgd. Blijft over het ijkpunt van de inhoud en strekking van de wettelijke regeling. Dat ijkpunt lijkt ons hier het meest bepalend. Wanneer uit de wettelijke regeling blijkt dat de toekenning van het bestuursrechtelijke handhavingsinstrumentarium uitputtend is bedoeld, dient er geen ruimte te zijn voor handhaving langs privaatrechtelijke weg. Dit laatste is echter maar zelden het geval.

Doorgaans biedt de wet het bestuursorgaan de bevoegdheid om met bestuursrechtelijke sancties op te treden en laat hij daarmee in het midden of er nog andere mogelijkheden voor het bestuursorgaan zijn. In die situatie zien wij niet in waarom het bestuursorgaan niet de ruimte zou mogen hebben te kiezen uit de bestuursrechtelijke of privaatrechtelijke handhavingsweg. Het geschikte beoordelingscriterium daarvoor is dan niet de doorkruisingsformule maar het legaliteitsbeginsel: is de bevoegdheidstoekenning uitputtend bedoeld, dan is er geen ruimte voor de privaatrechtelijke weg, maar anders is die er wel.

Voorts wijzen wij erop dat wij eerder, in het kader van een pleidooi voor uitbreiding van de bevoegdheden van de bestuursrechter via de band van de bestuursrechtelijke rechtsbetrekking, hebben gepleit voor de mogelijkheid van een preventieve rechterlijke toets bij de bestuurlijke handhaving. ${ }^{59}$ Daartoe zou het bestuur een vordering bij de bestuursrechter moeten kunnen instellen. De realisatie hiervan vergt echter niet minder dan een wijziging van het stelsel van rechtsbescherming; iets wat alleen al daarom waarschijnlijk nog heel lang toekomstmuziek blijft, als het al ooit wordt gerealiseerd. De uitbreiding van de mogelijkheid om langs privaatrechtelijke weg bij de burgerlijke rechter met succes een actie in te stellen ter handhaving van de overtreding van een publiekrechtelijk voorschrift, vraagt echter om een veel kleinere stap. Die kan immers binnen het huidige stelsel worden bewerkstelligd. De bevoegdheid om die preventieve toets te verrichten, zou echter wat ons betreft op termijn naar de bestuursrechter kunnen worden overgeheveld. ${ }^{60}$

Ter voorkoming van misverstanden ten slotte nog een punt dat bij de handhaving van publiekrechtelijke voorschriften van wezenlijk belang is. Het zou naar ons idee hier eigenlijk wel moeten gaan om het optreden tegen een overtreding in de zin van de Awb. Dat wil zeggen: het betreft het optreden tegen een gedraging die in strijd is met het bepaalde bij of krachtens enig wettelijk voorschrift (art. 5:I lid I Awb); de

59 F.J. van Ommeren \& P.J. Huisman, 'Van besluit naar rechtsbetrekking: een groeimodel', in: F.J. van Ommeren, P.J. Huisman, G.A. van der Veen, K.J. de Graaf, Het besluit voorbij (VAR preadviezen 2013), Den Haag: Boom Juridische uitgevers 2013, p. 6o e.v.

6o Evenzo: Scheltema \& Scheltema 2013, p. 46I, die de actie tot handhaving van publiekrechtelijke voorschriften als een publiekrechtelijke actie beschouwen, zelfs als deze bij de burgerlijke rechter plaatsvindt. 
overtreding dient bij of krachtens een aan de gedraging voorafgaand wettelijk voorschrift te zijn omschreven (art. 5:4 lid 2 Awb). Ook hier zou onzes inziens het legaliteitsbeginsel bepalend moeten zijn. Onvoldoende moet derhalve worden geacht dat - slechts - in strijd met een beleidsregel, nota of ander stuk is gehandeld of dat de overtreder slechts ongeschreven (zorgvuldigheids)normen heeft geschonden. Een dergelijke uitbreiding beogen wij met het bovenstaande niet te bepleiten. Dat lijkt vanuit een bestuursrechtelijk gezichtspunt wellicht tamelijk vanzelfsprekend, maar toch is het van belang hierop uitdrukkelijk te wijzen, nu de burgerlijke rechter juist op dit punt soms ruimhartiger pleegt te zijn. ${ }^{6}$ Een belangrijke reden dat het hier in onze ogen zou moeten gaan om de handhaving van wettelijke voorschriften, is dat de rechter geen democratische legitimatie kan verschaffen aan de te handhaven normen. ${ }^{62}$

\subsection{De ruimte voor twee wegen en de te hanteren maatstaven}

Met het Windmill-arrest en de daarin geformuleerde doorkruisingsformule is de ruimte om privaatrechtelijk te handelen aanzienlijk ingeperkt. Toch is de discussie over de ruimte die de overheid hiervoor moet hebben niet verstomd. De onvoorspelbaarheid en algemeenheid van de doorkruisingsformule vormen belangrijke punten van kritiek. Wij vinden, alhoewel deels de vinger op een zere plek wordt gelegd, deze kritiek niet helemaal 'fair'. Volledige zekerheid met een algemene maatstaf lijkt ons geen realistische wens. Als instrument voor rechtsvorming en rechtsontwikkeling biedt de doorkruisingsformule echter meer dan voldoende basis voor een beginpunt van de redenering. Dat blijkt ook uit de hiervoor gepresenteerde analyse. De concrete toepassingen van deze formule bieden rechtszekerheid, ook voor toekomstige gevallen. Van groot belang vinden wij dat er in de rechtspraak aan de hand van de toepassing van deze formule duidelijk te onderscheiden standaardsituaties zijn ontstaan en ook weer nieuwe standaardsituaties kunnen ontstaan. Het zijn deze standaardsituaties die houvast geven. Het is naar onze inschatting dan ook niet zo dat deze formule zijn langste tijd heeft gehad of zou moeten hebben gehad.

Daarbij komt dat de wetgever op verschillende momenten de kans heeft om in te grijpen. In de eerste plaats kan de wetgever zich in wet- en regelgeving uitdrukkelijk bij voorbaat uitlaten over de toelaatbaarheid van privaatrechtelijk overheidshandelen. Het zou goed zijn als dat vaker dan tot nu toe zou gebeuren. Bij het in het leven roepen van publiekrechtelijke bevoegdheden vormt de alternatieve mogelijkheid van het volgen van de privaatrechtelijke weg, uitzonderingen daargelaten, bij de wetgever nogal eens een blinde vlek. In de tweede plaats kan de wetgever de rechterlijke koers over de toelaatbaarheid van privaatrechtelijk handelen in een concreet geval bijstellen indien en voor zover hij dat wenselijk acht. Zoals we zagen, gebeurt dat een enkele keer in de praktijk.

6I Vgl. HR 8 februari I994, AB I994/4I5 m.nt. G.A. van der Veen (Kabayel), alwaar geen sprake was van een wettelijke regeling die werd gehandhaafd.

62 Vgl. N. Verheij, 'Een eigen rechter', in: A.J.C. de Moor-van Vugt, J.L. de Wijkerslooth \& N. Verheij, Verschuiving van de magische lijn (VAR preadviezen 1999), Alphen aan den Rijn: Samsom I999, p. 64,65 . 
Verschillende andere maatstaven passeerden de revue. Aan de orde kwam onder meer dat het legaliteitsbeginsel een begrenzing kan vormen voor de ruimte voor de overheid om privaatrechtelijk te handelen en dat het privaatrechtelijk overheidshandelen vanwege de samenhang met publiekrechtelijke bevoegdheden misbruik van een privaatrechtelijke bevoegdheid kan opleveren. De verschillende maatstaven kunnen ten dele overlappen, hetgeen overigens geen afbreuk doet aan de relevantie van de verschillende te onderscheiden maatstaven, nu zij elkaar ook kunnen aanvullen. Dit maakt de keuze voor de ene of de andere maatstaf soms lastig, doordat hun onderlinge verhouding niet altijd duidelijk is of duidelijk blijkt uit de rechtspraak.

Soms ligt de toepassing van de doorkruisingsformule naar onze mening minder voor de hand. Komt het privaatrechtelijk handelen in feite neer op een bepaalde vorm van niet toegestaan publiekrechtelijk handelen, dan rijst de vraag of dit handelen niet primair dient te worden beoordeeld aan de hand van de daarvoor geldende publiekrechtelijke normen, zoals het legaliteitsbeginsel. In dit verband valt bijvoorbeeld te wijzen op constructies waarbij de overheid privaatrechtelijke rechtspersonen opricht en daaraan feitelijk zonder adequate grondslag publiekrechtelijke bevoegdheden overdraagt.

Gelet op de ratio van de tweewegenleer en de doorkruisingsformule - het voorkomen dat langs privaatrechtelijke weg de belangen worden doorkruist waarvan de behartiging aan de overheid bij publiekrechtelijk regeling is toevertrouwd - rijst de vraag waarom naar geldend recht de overheid nog maar zo weinig ruimte krijgt om langs privaatrechtelijke weg publiekrechtelijke voorschriften te handhaven. Kenmerkend voor de handhaving langs privaatrechtelijke weg is immers de tussenkomst van de rechter; langs deze weg wordt derhalve de bescherming van de belangen van de burger niet verminderd. De huidige strenge toepassing van de doorkruisingsformule is op dit punt naar onze mening niet zinvol. Niet valt in te zien waarom bij de handhaving de keuze voor de bestuursrechtelijke of privaatrechtelijke weg niet aan het bestuur kan worden gelaten. De begrenzing zou dan primair gevonden kunnen worden in het legaliteitsbeginsel: is de publiekrechtelijke bevoegdheidstoekenning uitputtend bedoeld, dan is er geen ruimte voor de privaatrechtelijke handhavingsweg.

\section{Soorten overheidsovereenkomsten: een nadere classificatie}

\section{I Inleiding}

Teneinde de vraag naar de ruimte die de overheid heeft om overeenkomsten te sluiten goed te kunnen beantwoorden en te bezien welke beoordelingsmaatstaven daarvoor in aanmerking komen, is het nodig om eerst een onderscheid te maken tussen de verschillende soorten overheidsovereenkomsten. Daarna kan in het volgende hoofdstuk worden bezien in hoeverre de bevindingen van het vorige hoofdstuk kunnen worden toegepast op deze verschillende soorten overeenkomsten.

Zoals bekend, is het in veel rechtsstelsels, ook in het Nederlandse, niet ongebruikelijk de overheidsovereenkomsten te rubriceren in twee hoofdtypen, te weten 
de privaatrechtelijke en de publiekrechtelijke overeenkomsten. ${ }^{63}$ De wijze waarop in de doctrine het onderscheid tussen het ene en het andere type wordt gemaakt, verschilt echter nogal eens. Onderscheidend element voor de hier te presenteren classificatie is het object waarover wordt gecontracteerd: het gebruik van privaatrechtelijke middelen of publiekrechtelijke bevoegdheden.

Op die privaatrechtelijke en publiekrechtelijke overeenkomst gaan wij nu dieper in. Daarbij zullen wij een ietwat verdergaande nadere classificatie van de publiekrechtelijke overeenkomst presenteren dan in de literatuur gebruikelijk is. Maar vooraf nog een kort woord over de gemengde overeenkomst.

\subsection{Gemengde overeenkomsten}

Overheidsovereenkomsten kunnen in de praktijk zowel bedingen bevatten met een privaatrechtelijk als met een publiekrechtelijk karakter. In dat geval is sprake van zogeheten gemengde overeenkomsten. De gemengde overeenkomst komt vrij veel voor. Te wijzen valt op de overeenkomst waarin een gemeente afspreekt grond te ruilen en tevens afspreekt te zullen bevorderen dat de bestemming van de grond zal worden aangepast. ${ }^{6}$ Ten dele vormt de eigendom van de grond het onderwerp van het contract (privaatrechtelijke overheidsovereenkomst), en ten dele wordt gecontracteerd over de publiekrechtelijke bevoegdheid om het bestemmingsplan aan te passen (bevoegdhedenovereenkomst). Wij komen op de gemengde overeenkomst niet meer uitdrukkelijk terug: het hierna gezegde geldt uiteraard ook voor de bedingen van de gemengde overeenkomsten die respectievelijk een privaatrechtelijk of publiekrechtelijk karakter hebben.

\subsection{Privaatrechtelijke overheidsovereenkomsten}

De privaatrechtelijke overheidsovereenkomst is een overeenkomst over het gebruik van een bevoegdheid die de overheid op grond van het privaatrecht toekomt. Het betreft het type overeenkomst dat in beginsel door eenieder kan worden gesloten.

Het komt regelmatig voor dat deze overheidsovereenkomsten een sterk beleidsmatig karakter hebben. Bij wijze van voorbeeld valt te wijzen op contracten waarin de gemeente door middel van de overeenkomst bij de verkoop van bouwgrond bepaalde beleidsdoeleinden tracht te realiseren. In de algemene bestuursrechtelijke literatuur worden de privaatrechtelijke overheidsovereenkomsten derhalve wel nader onderverdeeld in twee subvarianten, te weten de beleidsneutrale privaatrechtelijke overheidsovereenkomsten en de beleidsovereenkomsten. ${ }^{65}$ Het onderscheidende criterium is of de overheid door te contracteren een beleidsdoel nastreeft.

Deze nadere onderverdeling is naar onze mening echter minder gelukkig. Vooropgesteld zij dat echt beleidsarme overheidsovereenkomsten eigenlijk niet bestaan;

63 Schlössels \& Zijlstra 20Io, p. 846 e.v.; Van Wijk/Konijnenbelt \& Van Male 20I4, p. 24I, 242 en Scheltema \& Scheltema 2013 , p. 203 e.v.

64 Zie voor een ander voorbeeld ABRvS 8 september 2004, AB 2004/458 m.nt. C.N.J. Kortmann (Wijziging Tracébesluit).

65 Zie bijvoorbeeld: Schlössels \& Zijlstra 20Io, p. 867-868. Vgl. Van Wijk/Konijnenbelt \& Van Male 20I4, p. 4I6-4I7. 
achter vrijwel iedere overheidshandeling, ook de privaatrechtelijke, gaat immers een beleidsdoel schuil. Dat komt doordat de overheid geacht wordt steeds op te treden in het algemeen belang. De overheid voert in beginsel stééds beleid, waardoor (nagenoeg) alle overheidsovereenkomsten tevens beleidsovereenkomsten zijn. ${ }^{66}$

Een onzes inziens groter bezwaar is dat aan het onderscheid tussen beleidsmatige en beleidsneutrale overeenkomsten in wetgeving en jurisprudentie geen rechtsgevolgen plegen te worden verbonden. Beide soorten privaatrechtelijke overheidsovereenkomsten vallen onder hetzelfde rechtsregime (zie voor dit rechtsregime uitvoeriger paragraaf 4.2).

Van belang is tenslotte nog dat vooral de fase van de totstandkoming van privaatrechtelijke overheidsovereenkomsten door middel van het aanbestedingsrecht nauwgezet is gereguleerd met ingrijpende wettelijke regels. Voor de toepasselijkheid van het aanbestedingsrecht wordt evenmin onderscheid gemaakt tussen overheidsopdrachten met een meer of minder beleidsmatig karakter (als dat al mogelijk zou zijn). Op het terrein van de overheidsinkoop is het inmiddels duidelijk dat het sluiten van inkoopcontracten (via een aanbestedingsprocedure) een middel is om verschillende beleidsdoelen te realiseren. Het gaat niet alleen meer om de 'beste kwaliteit tegen de laagste prijs', maar ook om het realiseren van andere doeleinden. ${ }^{67}$

$\mathrm{Al}$ met al laten wij daarom de in de literatuur wel gemaakte conceptuele onderscheiding tussen beleidsmatige en beleidsneutrale privaatrechtelijke overheidsovereenkomsten varen. Wij achten het niet wenselijk haar in de analyse van de geoorloofdheid van overheidsovereenkomsten te betrekken.

\subsection{Publiekrechtelijke overeenkomsten}

Publiekrechtelijke overeenkomsten zijn overeenkomsten die verband houden met de uitoefening van een publiekrechtelijke bevoegdheid. Het verband tussen de overeenkomst en de publiekrechtelijke bevoegdheid kan op verschillende manieren gestalte krijgen. Goed beschouwd, kan de overeenkomst op de uitoefening van de publiekrechtelijke bevoegdheid vooruitlopen of juist daaraan nadere uitvoering geven. Dit betekent dat er zich verschillende soorten verhoudingen tussen de overeenkomst en de uitoefening kunnen voordoen. Een publiekrechtelijke overeenkomst kan derhalve, afhankelijk van de precieze inhoud daarvan, op het eerste gezicht op de volgende manieren aan de publiekrechtelijke bevoegdheidsuitoefening zijn gerelateerd: de overeenkomst kan vooruitlopen op de publiekrechtelijke bevoegdheidsuitoefening (bevoegdhedenovereenkomst) en de overeenkomst kan volgen op de uitoefening van de publiekrechtelijke bevoegdheid (uitvoeringsovereenkomst).

66 Zie D.A. Lubach, Beleidsovereenkomsten. Een onderzoek naar juridische aspecten van het gebruik van de overeenkomst als beleidsinstrument door de overheid (diss. Groningen), Deventer: Kluwer 1982, p. I4, waar de term 'beleidsovereenkomst' wordt gebruikt voor alle situaties waarin het gaat om het beleidsgerichte gebruik van overeenkomsten door overheden.

67 Zulks blijkt ook uit de recente aanbestedingsregelgeving, zoals de Aanbestedingswet 2012 met de bijbehorende 'Gids Proportionaliteit', zie o.a. G.W.A. van de Meent, A. Stellingwerff Beintema \& R.S. Damsma, 'De (nieuwe) Aanbestedingswet (Deel I)', TBR 2013/40, p. 244-245 en C.E.C. Jansen, 'Bouwen met de nieuwe Aanbestedingswet: over het clusterverbod in de context van de aanbesteding van geïntegreerde bouworganisatievormen', TBR 2013/III, p. 747. 


\section{De bevoegdhedenovereenkomst}

Een bevoegdhedenovereenkomst is een overeenkomst waarin de overheid met burgers of medeoverheden afspreekt hoe zij haar publiekrechtelijke bevoegdheden in de toekomst zal gaan gebruiken. ${ }^{68}$ De bevoegdhedenovereenkomst heeft een anticiperend karakter. $\mathrm{Zij}$ loopt op de eigenlijke bevoegdheidsuitoefening vooruit. Het bestuursorgaan maakt door het sluiten van een bevoegdhedenovereenkomst inzichtelijk op welke wijze het de aan hem toegekende bevoegdheid zal gaan gebruiken en het verbindt zich om zich overeenkomstig het bepaalde te gaan gedragen. ${ }^{69}$ Uit de bevoegdhedenovereenkomst vloeit een bestuursrechtelijke rechtsbetrekking voort tot het (wel of niet) nemen van een bepaald besluit. ${ }^{70}$

In beginsel kunnen over uiteenlopende publiekrechtelijke bevoegdheden bevoegdhedenovereenkomsten worden gesloten. In de literatuur en jurisprudentie gaat de meeste aandacht uit naar de overeenkomsten waarin is gecontracteerd over het nemen van besluiten in de zin van art. I:3 Awb, zoals beschikkingen, concretiserende besluiten van algemene strekking en algemeen verbindende voorschriften. Dit neemt niet weg dat het eveneens mogelijk is om over andere typen publiekrechtelijke (rechts)handelingen te contracteren, zoals het tot stand brengen van wetgeving in formele zin. ${ }^{71}$ Overeenkomsten waarbij afspraken worden gemaakt over feitelijk overheidshandelen dat een specifieke publiekrechtelijke grondslag heeft, zijn ook als bevoegdhedenovereenkomsten aan te merken. ${ }^{22}$

Opmerkelijk genoeg wordt aan de principiële vraag of een bestuursorgaan überhaupt over het gebruik van zijn publiekrechtelijke bevoegdheden overeenkomsten mag sluiten, in de Nederlandse doctrine weinig tot geen aandacht besteed. Toch is die mogelijkheid op het eerste gezicht niet geheel vanzelfsprekend. Met name de wettelijke grondslag, waarop de publiekrechtelijke bevoegdheid is gebaseerd, brengt tot uitdrukking welk soort handelingen het bestuursorgaan dient te verrichten om de toegekende bestuursbevoegdheid te kunnen uitoefenen. Daaruit volgt niet dat het bestuursorgaan bevoegd is om een overeenkomst te sluiten, maar veeleer dat het bestuursorgaan vergunningen kan verlenen, subsidies kan verstrekken enzovoort. Uit de wet blijkt niet dat het aan het bestuursorgaan is toegestaan over het gebruik van de publiekrechtelijke bevoegdheid zelf overeenkomsten te sluiten. In het licht van het legaliteitsbeginsel ligt het dan ook niet meteen voor de hand dat

68 In dit preadvies staan overeenkomsten centraal waarin wordt gecontracteerd over een staats- en/ of bestuursrechtelijke publiekrechtelijke bevoegdheid. Overeenkomsten over strafrechtelijke bevoegdheden blijven op deze plaats buiten beschouwing. Zie ter zake J.H. Crijns, De strafrechtelijke overeenkomst. De rechtsbetrekking met het Openbaar Ministerie op het grensulak van publiek- en privaatrecht (diss. Leiden), Deventer: Kluwer 2010.

69 Zie uitvoerig over de bevoegdhedenovereenkomst: P.J. Huisman, De bevoegdhedenovereenkomst. De overeenkomst over het gebruik van een publiekrechtelijke bevoegdheid (diss. Amsterdam VU), Den Haag: Boom Juridische uitgevers 2012.

70 Van Ommeren \& Huisman 2013, paragraaf 4.3.

$7 \mathrm{I}$ Wetgeving in formele zin wordt niet aangemerkt als een besluit in de zin van de Awb. Dit komt doordat de formele wetgever is uitgezonderd van het bestuursorgaanbegrip. Zie art. I:I lid 2 sub a jo. $\mathrm{I}: 3$ lid I Awb.

72 Zie Schlössels \& Zijlstra 20I0, p. 885 en Scheltema \& Scheltema 20I3, p. 209. Zij noemen als voorbeeld de overeenkomst waarin afspraken over politieoptreden worden opgenomen. 
het bestuursorgaan deze bevoegdheid heeft. Dit is slechts anders als de bevoegdhedenovereenkomst een uitdrukkelijke wettelijke grondslag heeft, hetgeen slechts bij uitzondering het geval is. In het Nederlandse bestuursrecht wordt echter zonder veel omhaal van woorden over deze doctrinaire hobbel heen gestapt. In de algemene bestuursrechtelijke literatuur wordt de mogelijkheid van het aangaan van een bevoegdhedenovereenkomst op zichzelf al jaren onderkend..$^{73}$ Iets anders is dat de rechtspraktijk, naar onze indruk, niet steeds als vanzelf op het idee komt dat over een toegekende publiekrechtelijke bevoegdheid een overeenkomst kan worden gesloten; vermoedelijk gebeurt dat niet om de eenvoudige reden dat de wet dit niet tot uitdrukking brengt en de bestuurscultuur niet met zich brengt dat die mogelijkheid onder ogen wordt gezien.

Een vlugge blik over de grenzen leert overigens dat in andere rechtstelsels de doctrine wel fundamentele bezwaren kan hebben tegen de idee van de bevoegdhedenovereenkomst. Dit kan tot gevolg hebben dat bij het concept van de publiekrechtelijke overeenkomst zelfs in het geheel niet aan een bevoegdhedenovereenkomst wordt gedacht. Het bestaan van de bevoegdhedenovereenkomst als denkbare rechtsfiguur wordt eenvoudigweg niet onderkend of men betwijfelt zeer dat het sluiten van een overeenkomst over het gebruik van een publiekrechtelijke bevoegdheid rechtens mogelijk zou zijn (behoudens de specifieke gevallen waarin de wetgever zulks uitdrukkelijk mogelijk heeft gemaakt). ${ }^{74} \mathrm{Bij}$ een publiekrechtelijke overeenkomst wordt in het internationale juridische discours veeleer aan een overeenkomst gedacht die in de plaats komt van het gebruik van een publiekrechtelijke bevoegdheid. Met andere woorden: aan een besluitvervangende overeenkomst. ${ }^{75}$ Waar men in het buitenland voorts wel meer mee vertrouwd is, is een traject dat publiekrechtelijk begint en met een overeenkomst eindigt; met andere woorden: met de uitvoeringsovereenkomst.

De uitvoeringsovereenkomst

De uitvoeringsovereenkomst volgt op de uitoefening van een publiekrechtelijke bevoegdheid. Deze overeenkomst wordt gesloten ter uitvoering van het besluit dat is genomen op grond van de publiekrechtelijke bevoegdheid. Zij is pas aan de orde

73 Men zie ook de oudere drukken van de thans gangbare bestuursrechtelijke handboeken. Zo wordt in oudere drukken van Hoofdstukken van bestuursrecht weliswaar aandacht besteed aan de Landsmeerarresten, waarin de toelaatbaarheid wordt aangenomen, maar wordt het onderhavige punt niet (verder) geproblematiseerd, zie H.D. van Wijk, Hoofdstukken van administratief recht, 's-Gravenhage: Wolters-Noordhoff \& VUGA-Boekerij I968, p. 153 en H.D. van Wijk \& W. Konijnenbelt, Hoofdstukken van administratief recht, Den Haag: VUGA-Boekerij I976, p. IIo-III. In de eerste druk van Bestuursrecht in de sociale rechtsstaat wordt het sluiten van bevoegdhedenovereenkomsten eveneens niet als problematisch gezien: P. de Haan, Th.G. Drupsteen \& R. Fernhout, Bestuursrecht in de sociale rechtsstaat. Instrument en waarborg, Deventer: Kluwer 1978, p. 294, 295-296, 301-303.

74 Zie de landenrapporten in: R. Noguellou \& U. Stelkens (eds.), Droit comparé des Contracts Publics; Comparative Law on Public Contracts, Brussel: Bruylant 2010.

75 Wellicht komt dat doordat het Duitse recht een algemene wettelijke regeling kent met de mogelijkheid tot een besluitvervangende overeenkomst. Zie U. Stelkens \& H. Schröder, Allemagne/ Germany, in: Noguellou \& Stelkens (eds.), 2010, p. 307 e.v. en ten onzent: M.H. Kobussen, 'Beschikkingvervangende overeenkomsten en overeenkomsten tussen overheden als bijzondere (bestuurs)overeenkomsten?', WPNR I992, p. 995, 996. 
nadat de bevoegdheid waarop zij betrekking heeft is uitgeoefend en heeft een accessoir karakter. De uitvoeringsovereenkomst heeft dus een wezenlijk andere relatie met de publiekrechtelijke besluitvorming dan de bevoegdhedenovereenkomst. Uitvoeringsovereenkomsten zien immers op een andere fase, de fase na de besluitvorming. Deze overeenkomsten bepalen niets over de inhoud van een te nemen besluit. Ook hier is sprake van een verband tussen besluit en overeenkomst, maar zij is van andere aard dan die van de bevoegdhedenovereenkomst. ${ }^{76}$

Uitzonderingen daargelaten beschikt de uitvoeringsovereenkomst niet over een specifieke wettelijke grondslag. De bevoegdheid om een uitvoeringsovereenkomst te sluiten vloeit voort uit de bevoegdheid van het bestuursorgaan om een publiekrechtelijke bevoegdheid uit te oefenen. In dit opzicht lijkt de uitvoeringsovereenkomst op de bevoegdhedenovereenkomst.

Naar onze ervaring in internationale onderzoeksfora ${ }^{77}$ roept de uitvoeringsovereenkomst in het rechtsvergelijkende wetenschappelijke discours meer herkenning op dan de bevoegdhedenovereenkomst. Vermoedelijk komt dat doordat de totstandkomingsfase van veel uitvoeringsovereenkomsten onder het regime van het aanbestedingsrecht valt, waarmee men over het algemeen al meer vertrouwd is. De rechtsbetrekking vloeit voort uit een aantal eenzijdige overheidsbeslissingen die een contractuele uitwerking krijgen. De omgekeerde situatie - eerst wordt een overeenkomst gesloten en daarna pas een publiekrechtelijk besluit genomen - zoals bij de bevoegdhedenovereenkomst, herkent men veel minder.

\subsection{Besluitvervangende overeenkomsten}

Het komt voor dat overheidsovereenkomsten worden gesloten als alternatief voor de uitoefening van een publiekrechtelijke bevoegdheid. Deze overeenkomsten zijn aan te duiden als besluitvervangende overeenkomsten. Zij beogen immers in de plaats te komen van een publiekrechtelijk besluit. Dat kan op verschillende manieren gebeuren. Het is denkbaar dat de overheid in plaats van de publiekrechtelijke bevoegdheid uit te oefenen een privaatrechtelijke overeenkomst sluit. Te denken valt aan het geval dat de eigendom van de grond voor de overheid de titel vormt om in plaats van een publiekrechtelijk besluit te nemen een overeenkomst te sluiten.

Het is echter ook goed denkbaar dat het bestuursorgaan zich met de overeenkomst verbindt om af te zien van de uitoefening van een publiekrechtelijke bevoegdheid onder de voorwaarde dat de wederpartij voldoet aan de in de overeenkomst opgenomen bedingen. Deze besluitvervangende overeenkomst heeft het karakter van de zojuist genoemde bevoegdhedenovereenkomst: er wordt immers gecontracteerd over het niet-uitoefenen van een publiekrechtelijke bevoegdheid. De publiekrechtelijke bevoegdheid biedt de titel voor de contractueel vast te leggen toezegging dat de publiekrechtelijke bevoegdheid niet zal worden uitgeoefend. Zij vormt voor de overheid de basis voor het aangaan van deze overeenkomst.

Dit brengt met zich dat er twee soorten besluitvervangende overeenkomsten zijn te onderscheiden, afhankelijk van de titel op grond waarvan de overeenkomst aan

76 Van Ommeren \& Huisman 20I3, p. 34 e.v. en p. 64.

77 Zie paragraaf $\mathbf{\text { I.2. }}$ 
overheidszijde wordt gesloten: de privaatrechtelijke en de publiekrechtelijke. In zoverre vertoont de besluitvervangende overeenkomst overlap met de privaatrechtelijke overeenkomst en de bevoegdhedenovereenkomst. We zouden ook kunnen zeggen dat de besluitvervangende overeenkomst conceptueel beschouwd niet zozeer een separate rechtsfiguur is, maar dat het vervangen van een besluit veeleer een functie is die zowel door privaatrechtelijke overheidsovereenkomsten als bevoegdhedenovereenkomsten kan worden vervuld.

De besluitvervangende overeenkomst kan in beginsel in de plaats komen van verschillende soorten besluiten. Met het oog op de beantwoording van de vraag naar de ruimte die er voor dit soort overeenkomsten is, is het zinvol dit type overeenkomst nader te onderscheiden in de overeenkomst die in de plaats komt van een beschikking - de beschikkingvervangende overeenkomst - en de overeenkomst die in de plaats komt van wet- en regelgeving - de regelvervangende overeenkomst. Dat hier sprake is van een alternatieve weg is mede bepalend voor de ruimte die er voor het sluiten van dit soort overeenkomsten is, zoals zo meteen bij de bespreking ervan zal blijken (zie paragraaf $4 \cdot 5$ ).

\subsection{Typologie van publiekrechtelijke overeenkomsten}

De hier gepresenteerde hoofdindeling in publiek- en privaatrechtelijke overheidsovereenkomsten is in de Nederlandse juridische literatuur tamelijk gebruikelijk, ofschoon de terminologie soms wel eens verschilt. Maar over de nadere rubricering bestaat in de literatuur geen eenstemmigheid, in het bijzonder niet ten aanzien van de publiekrechtelijke overeenkomsten.

Bekend is de al wat oudere typologie van De Haan c.s., die maar liefst twaalf soorten overheidscontracten onderscheidden. Hoewel deze verfijnde indeling een goed inzicht geeft in veel (maar zeker niet alle) mogelijke publiekrechtelijke en privaatrechtelijke varianten, is het bezwaar daarvan dat niet aan alle onderscheiden typen eigen rechtsgevolgen kunnen worden toegedacht. Dat maakt deze typologie uit juridisch oogpunt minder interessant. Door de bewerkers van dit boek is zij later gereduceerd tot veel minder varianten, waarbij met name wordt gelet op de privaatrechtelijke of publiekrechtelijke vorm dan wel de privaatrechtelijke of publiekrechtelijke inhoud van de overeenkomst. ${ }^{78}$ Ook die aanpak achten wij in zoverre minder gelukkig dat de overeenkomst met haar vorm van aanbod en aanvaarding een algemeen juridische figuur is die het onderscheid tussen publiek- en privaatrecht overstijgt. Aantrekkelijk achten wij evenwel de aandacht voor de inhoudelijke kant: zoals gezegd, hebben ook wij gekeken naar het object van de overeenkomst.

In de recente literatuur worden bovendien de uitvoeringsovereenkomsten doorgaans niet onderscheiden van de bevoegdhedenovereenkomsten, naar het voorkomt omdat zij beide betrekking hebben op een besluit. ${ }^{79} \mathrm{Wij}$ delen de opvatting dat uitvoeringsovereenkomsten (inderdaad) als publiekrechtelijke overeenkomsten moeten worden opgevat, maar wij achten de aanduiding als bevoegdhedenovereenkomst niet aantrekkelijk, omdat zij de andere relatie miskent die

78 Schlössels \& Zijlstra 20Io, p. 865, 866.

79 Scheltema \& Scheltema 20I3, p. 209. 
uitvoeringsovereenkomsten ten opzichte van een besluit hebben. Voor de beantwoording van de vraag in hoeverre er ruimte is om overeenkomsten te sluiten achten wij het wenselijk deze uiteenlopende verhoudingen goed in het oog te houden. Overigens is het evenmin zinvol beide soorten overeenkomsten voor de rechtsbescherming op een hoop te gooien. ${ }^{80}$

Wij menen dat het derhalve vruchtbaarder is in het bijzonder te kijken naar de verhouding tussen de overeenkomst en de (eenzijdige) publiekrechtelijke besluitvorming. Voor de door ons gepresenteerde rubricering van de publiekrechtelijke overeenkomst is steeds gelet op de verhouding tussen de overeenkomst en de publiekrechtelijke bevoegdheidsuitoefening. Zoals gezegd, kan de overeenkomst voorafgaan aan of volgen op de publiekrechtelijke bevoegdheidsuitoefening. Voorts kan de overeenkomst in de plaats komen van de publiekrechtelijke bevoegdheidsuitoefening. Deze typologie maakt het goed mogelijk de rechtsgevolgen die uit deze verschillende rechtsverhoudingen kunnen voortvloeien, in kaart te brengen; hetgeen wij in het volgende hoofdstuk voor de geoorloofdheidsvraag zullen doen.

\subsection{De betekenis van de kwalificatie van de overeenkomst als 'publiekrechtelijk'}

Wij hebben hiervoor, vanwege de nauwe band met de publiekrechtelijke bevoegdheidsuitoefening, zowel bevoegdhedenovereenkomsten als uitvoeringsovereenkomsten als 'publiekrechtelijk' aangeduid. In de bestuursrechtelijke literatuur is het niet ongebruikelijk (in ieder geval) de bevoegdhedenovereenkomst als publiekrechtelijk aan te merken.

Met de kwalificatie van deze overeenkomsten als 'publiekrechtelijk' van aard wordt enige afstand genomen van het thans geldende recht. Dat blijkt zowel als we naar de wetgeving kijken als naar de rechtspraak. Zo verbiedt art. I22 Woningwet de gemeente om 'rechtshandelingen naar burgerlijk recht' te verrichten ten aanzien van de onderwerpen waarop deze wet betrekking heeft. Onder deze rechtshandeling naar burgerlijk recht moet in het bijzonder ook het verbod worden begrepen een bevoegdhedenovereenkomst te sluiten over een omgevingsvergunning voor het bouwen. ${ }^{81}$ Het is derhalve van belang niet uit het oog te verliezen dat waar de wetgever spreekt over een privaatrechtelijke rechtshandeling, het niet uitgesloten is dat mede een in onze ogen publiekrechtelijke overeenkomst wordt bedoeld.

Hetzelfde geldt voor de rechter. Het is immers meestal de burgerlijke rechter die bevoegd is om kennis te nemen van geschillen omtrent publiekrechtelijke overeenkomsten. Dat geldt in ieder geval voor de vorderingen van de overheid jegens de

8o Eerder hebben wij - met het oog op de rechtsbescherming - onderscheiden tussen bevoegdhedenovereenkomsten en uitvoeringsovereenkomsten in: Van Ommeren \& Huisman 20I3, p. 34 e.v. en - met het oog op een mogelijke wettelijke regeling - in: F.J. van Ommeren, 'De bevoegdhedenovereenkomst in de Awb en de verhouding met het BW', in: T. Barkhuysen, W. den Ouden \& J.E.M. Polak (red.), Bestuursrecht harmoniseren: 15 jaar Awb, Den Haag: Boom Juridische uitgevers 20Io, p. 720 .

8I HR 4 april 2003, AB 2004/6o m.nt. G.A. van der Veen en HR I7 juni 20II, AB 20II/330 m.nt. F.J. van Ommeren (Van Sundert/Breda). 
burger, maar ook in het omgekeerde geval is dat doorgaans niet anders. Overeenkomsten worden immers niet als besluit in de zin van art. I:3 lid I Awb aangemerkt.

Zelfs de bevoegdhedenovereenkomst zelf wordt door de bestuursrechter als een privaatrechtelijke rechtshandeling beschouwd. Derhalve staat er ook tegen deze overeenkomst geen rechtsbescherming bij de bestuursrechter open. ${ }^{82}$ Dit neemt niet weg dat de uitvoeringshandeling van een bevoegdhedenovereenkomst aan overheidszijde een voor beroep vatbaar besluit kan zijn. Tegen dergelijke uitvoeringsbesluiten kan slechts bij de bestuursrechter worden opgekomen. Diens bevoegdheid is exclusief: de burgerlijke rechter heeft geen rol als aanvullende rechter om een vordering tot nakoming van de uit de bevoegdhedenovereenkomst voortvloeiende verplichting tot het nemen van een appellabel besluit te beoordelen. Voor wat betreft een (eventuele) schadevergoedingsvordering ligt een en ander aanmerkelijk gecompliceerder. Schadevergoeding kan gevorderd worden op grond van twee te onderscheiden titels. Schadevergoeding wegens onrechtmatige besluitvorming kan in bepaalde gevallen alleen bij de burgerlijke rechter, dan wel de bestuursrechter worden gevraagd. In sommige gevallen heeft de burger keuzevrijheid (zie art. 8:89 Awb). Een vordering tot schadevergoeding wegens wanprestatie (vanwege het niet-nakomen van de overeenkomst) kan echter slechts aan de burgerlijke rechter voorgelegd worden. ${ }^{83}$ Vanwege het feit dat aldus beide rechters zich over geschillen over bevoegdhedenovereenkomsten kunnen buigen, duidt de Hoge Raad de bevoegdhedenovereenkomst sinds kort aan als een overeenkomst met 'een gemengd (privaatrechtelijk en bestuursrechtelijk) karakter' ${ }^{84}$ Dat neemt echter niet weg dat ook in deze rechtspraak de bevoegdhedenovereenkomst zelf privaatrechtelijk van aard wordt geacht en slechts de uitvoering daarvan publiekrechtelijk. ${ }^{85}$

Ook voor het op de overeenkomst toepasselijke recht moeten aan de kwalificatie van deze overeenkomsten als 'publiekrechtelijk' geen al te exclusieve gevolgen worden verbonden. Op deze overeenkomsten is naar geldend recht een mix van publiekrechtelijke en privaatrechtelijke rechtsregels van toepassing. Die regels kunnen zowel van geschreven als ongeschreven aard zijn. Zolang algemene publiekrechtelijke wettelijke voorschriften voor overheidscontracten ontbreken, valt bij de geschreven rechtsregels in het bijzonder te denken aan de privaatrechtelijke rechtsregels - zoals de bepalingen voor de obligatoire overeenkomst van

82 Dit sluit echter niet uit dat deze overeenkomsten bij de bestuursrechter een rol kunnen spelen, in het bijzonder in het kader van de toetsing van het uitvoeringsbesluit aan het vertrouwensbeginsel. Zie o.a. ABRvS 8 september 2004, AB 2004/458 m.nt. C.N.J. Kortmann (Wijziging Tracébesluit). Zie in deze zin ook HR 8 juli 20II, AB $201 \mathrm{I} / 298$ m.nt. F.J. van Ommeren \& G.A. van der Veen, TBR 20II/202 m.nt. P.J. Huisman (Etam/Zoetermeer). Zie uitvoeriger over deze materie P.J. Huisman, 'De bevoegdhedenovereenkomst: hoe het niet nakomen van een inspanningsverplichting tot een schadevergoedingsverplichting kan leiden', JBplus 20r3a, p. 7 e.v.

83 HR 8 juli 20II, AB 20II/298 m.nt. F.J. van Ommeren \& G.A. van der Veen, TBR 20II/202 m.nt. P.J. Huisman (Etam/Zoetermeer).

84 HR 8 juli 20II, AB 20II/298 m.nt. F.J. van Ommeren \& G.A. van der Veen, TBR 20II/202 m.nt. P.J. Huisman (Etam/Zoetermeer).

85 Hetgeen ook blijkt uit het hiervoor genoemde arrest Etam/Zoetermeer en eerdere arresten als HR 3 april I998, AB I998/24I m.nt. Th.G. Drupsteen (Alkemade/Hornkamp) en HR 2 mei 2003, AB 2003/354 m.nt. E.W.J. de Groot \& G.A. van der Veen (Nunspeet/Mulder). 
art. 6:2I7 e.v. BW - die (al dan niet) analoog kunnen worden toegepast. Bij het ongeschreven publiekrecht valt in het bijzonder te denken aan de toepasselijkheid van de grondrechten en de algemene beginselen van behoorlijk bestuur. ${ }^{86} \mathrm{Bij}$ het ongeschreven privaatrecht valt op het eerste gezicht te denken aan de tweewegenleer met zijn doorkruisingsformule, zoals die door de rechter is ontwikkeld. Wij zullen hierna bezien of en in hoeverre deze leer bepalend is voor de ruimte om overheidsovereenkomsten te sluiten.

\section{$4 \quad$ Ruimte voor overheidsovereenkomsten}

\section{I Inleiding}

In dit hoofdstuk is de vraag aan de orde in hoeverre de overheid de ruimte heeft om ter uitvoering van haar taak overeenkomsten te sluiten. Daarbij volgen wij de conceptuele indeling in de verschillende soorten overheidsovereenkomsten die in het vorige hoofdstuk uit de doeken is gedaan, tussen enerzijds de privaatrechtelijke overeenkomst en anderzijds de bevoegdhedenovereenkomst en de uitvoeringsovereenkomst. Het bleek dat zowel de privaatrechtelijke overheidsovereenkomst als de bevoegdhedenovereenkomst kunnen worden gebruikt om een besluit te vervangen (de besluitvervangende overeenkomst). In het licht van de in hoofdstuk 2 geanalyseerde maatstaven zal het niet verwonderen dat hier nu het accent zal liggen op de vraag welke overeenkomsten zijn onderworpen aan de doorkruisingsformule van de burgerlijke rechter en voor welke overeenkomsten publiekrechtelijke waarborgen meer bepalend zijn.

Een bijzonder aspect van het overheidsovereenkomstenrecht is de positie van derden-belanghebbenden die geen partij zijn bij het contract. Deze dreigen meer dan in het bestuursrecht buiten de boot te vallen. Vandaar dat wij aan deze derden extra aandacht besteden.

\subsection{Privaatrechtelijke overheidsovereenkomsten}

Over de privaatrechtelijke overheidsovereenkomsten kunnen we hier betrekkelijk kort zijn, aangezien de ruimte om deze overeenkomsten te sluiten, conform de in hoofdstuk 2 beschreven lijnen, naast de doorkruisingsformule wordt bepaald door de daar genoemde alternatieve maatstaven. Wij gaan nu op enige van deze maatstaven dieper in.

\section{Onaanvaardbare doorkruising}

Of en in hoeverre de overheid een privaatrechtelijke overeenkomst mag sluiten, hangt in het bijzonder af van de (mogelijk) te doorkruisen publiekrechtelijke

86 Ter voorkoming van misverstanden: een aantal algemene beginselen van behoorlijk bestuur is weliswaar in - hoofdstukken 3 en 4 van - de Awb gecodificeerd, maar zij zijn daarmee nog niet zonder meer van toepassing op het privaatrechtelijk overheidshandelen, vgl. ook art. 3:I lid 2 Awb. Zij gelden in belangrijke mate als ongeschreven recht; met andere woorden: op grond van de rechtspraak. 
regeling. ${ }^{87}$ Zo wordt de toelaatbaarheid van anti-speculatiebedingen in gemeentelijke gronduitgifteovereenkomsten door de Hoge Raad beoordeeld aan de hand van de maatstaven in het Windmill-arrest: men zie daarvoor bijvoorbeeld het arrest Doetinchem/Rietbergen. ${ }^{88}$ In dit arrest is het de vraag of de genoemde contractuele bedingen een onaanvaardbare doorkruising opleveren van de Huisvestingswet. ${ }^{89}$ In privaatrechtelijke overeenkomsten opgenomen antispeculatiebedingen die niet zien op de verdeling van woonruimte en die geen beperkingen aanbrengen op het recht van vrije vestiging, zijn niet in strijd met het systeem en de strekking van de Huisvestingswet. Antispeculatiebedingen zijn derhalve geoorloofd, maar sociaal-economische bindingseisen kunnen niet langs contractuele weg worden gesteld.

Dat privaatrechtelijke overheidsovereenkomsten kunnen worden gebruikt naast of in plaats van het publiekrechtelijke instrumentarium wordt reeds geïllustreerd door het arrest Kunst- en Antiekstudio Lelystad.${ }^{90}$ De gemeente Lelystad had in de verkoopvoorwaarden van een bepaald gedeelte van haar bedrijventerrein de clausule opgenomen dat verhuur van ruimten goedkeuring van de gemeente behoeft. De rechtsvraag was of dergelijke privaatrechtelijke bedingen toelaatbaar zijn, zeker nu het gebruik van de grond reeds wordt (dan wel kan worden) gereguleerd via het publiekrechtelijke bestemmingsplan. De Hoge Raad beantwoordt deze vraag aan de hand van de doorkruisingsformule bevestigend. Hij overweegt dat de Wet op de Ruimtelijke Ordening (oud) niet in de weg staat aan het opnemen van voorwaarden omtrent grondgebruik in overeenkomsten, ook niet als door of krachtens de voorwaarden in bepaalde gevallen gebruik van de grond wordt beperkt of verboden, respectievelijk kan worden beperkt of verboden, dat volgens het vigerende bestemmingsplan in het algemeen geoorloofd is. Daarbij kent hij veel gewicht toe aan het ijkpunt 'inhoud en strekking van de regeling'. Aan de hand van een analyse van de parlementaire geschiedenis van de WRO wordt meer in het bijzonder gewezen op het feit dat de vraag naar de toelaatbaarheid van dit privaatrechtelijk overheidshandelen niet aan de orde is geweest bij de totstandkoming van deze wet en dat deze praktijk reeds lang bestaat en plotseling rechterlijk ingrijpen uitermate bezwaarlijk is met het oog op de zekerheid omtrent de rechtstoestand van onroerend goed. Hij overweegt in aansluiting hierop dat het op de weg van de wetgever ligt om in deze praktijk in te grijpen. De Hoge Raad heeft ook oog voor de waarborgen die zien op de belangen van de burger en wijst (onder meer) op het feit dat een gemeente bij het hanteren van dergelijke voorwaarden is gebonden aan de algemene beginselen van behoorlijk bestuur. Hierdoor worden de gerechtvaardigde belangen van grondgebruikers voldoende beschermd in dit type situaties, aldus de Hoge Raad. Dit arrest vindt zijn bevestiging in het latere arrest Chidda. ${ }^{9 \mathrm{I}}$ Ook

87 HR 26 januari I990, NJ I99I/393, AB I990/408 m.nt. G.P. Kleijn, AB Klassiek 2009/15 m.nt. H.Ph.J.A.M. Hennekens (Windmill). Soms past de Hoge Raad niet expliciet de maatstaven toe uit het Windmill-arrest, maar zijn in de overwegingen wel duidelijk de diverse ijkpunten te onderkennen, zie bijvoorbeeld HR 6 januari 2006, AB 2006/2I8 m.nt. E.W.J. de Groot \& G.A. van der Veen (Groenovereenkomst), waarover eerder paragraaf 2.3.

88 HR I4 april 2006, AB 2006/I98 m.nt. J.J. Hoekstra \& G.A. van der Veen (Doetinchem/Rietbergen).

89 Vgl. meer recent: HR 2I september 20I2, AB 2013/220 m.nt. F.J. van Ommeren (Cohabitat/Lisse).

90 HR 8 juli I99I, AB I99I/659 m.nt. F.H. van der Burg (Kunst- en antiekstudio Lelystad).

9I HR 24 december 2004, AB 2005/58 m.nt. G.A. van der Veen (Chidda). 
uit dit arrest volgt dat een privaatrechtelijk beding dat grondgebruik verder beperkt dan het bestemmingsplan, geoorloofd is.

\section{Alternatieve maatstaven}

Wanneer het sluiten van privaatrechtelijke overeenkomsten niet expliciet is verboden door de wet maar qua inhoud daarmee in strijd is, wordt aangenomen dat er geen ruimte is voor het contract. Dit lijkt daarmee sterk op toepassing van de 'voorvraag' uit het Windmill-arrest. ${ }^{92}$ In dit verband kan bijvoorbeeld gewezen worden op het arrest Parkeerexploitatie Amsterdam. ${ }^{93}$ De gemeente Amsterdam had aan Parkeerexploitatie Amsterdam B.V. het openbare parkeerterrein aan het Concertgebouwplein verhuurd. In de overeenkomst was opgenomen dat het terrein zou worden afgesloten met een slagboom en dat Parkeerexploitatie Amsterdam B.V. zorg zou dragen voor betaald en beheerd parkeren. De Hoge Raad acht deze overeenkomst nietig, niet omdat de wet uitdrukkelijk aan deze rechtshandeling in de weg staat, maar omdat het contract de gemeente dwingt tot een met de wet strijdige beperking in het gebruik van de weg. Het afsluiten van de openbare weg met het oog op betaald parkeren is geen beperking die op grond van de artikelen 6 en 14 Wegenwet is toegestaan.

De recente verfijning van de tweewegenleer, onder meer blijkend uit het misbruikcriterium van het arrest Amsterdam/Geschiere (dat eerder in paragraaf 2.4 aan de orde kwam), is in het bijzonder van belang voor de ruimte om privaatrechtelijke overheidsovereenkomsten te sluiten. Traditioneel uitgangspunt is dat een publiekrechtelijke toestemming niet als vanzelf een privaatrechtelijke overheidstoestemming voor een bepaald (dat wil zeggen: bijzonder) gebruik van overheidszaken met zich brengt. ${ }^{94} \mathrm{De}$ vraag is of de ruimte die er voor de overheid is om een privaatrechtelijke toestemming te weigeren, gebruikt kan worden om (slechts) een tegenprestatie te verlangen. Gedacht kan worden aan huurovereenkomsten of gebruiksovereenkomsten waarin met het oog op het gebruik van overheidsgrond door de burger financiële afspraken worden opgenomen. Zo is het in het nu kort te bespreken arrest Hoogheemraadschap/Götte de vraag of naast een publiekrechtelijke ontheffing voor het hebben van een steiger plaats is voor privaatrechtelijke toestemming waaraan een financiële voorwaarde is verbonden voor het gebruik van de waterbodem waarop de steiger rust. ${ }^{95}$

De ruimte om dergelijke bedingen in de overeenkomst op te nemen, is niet onbeperkt. Uit het arrest Amsterdam/Geschiere volgt immers dat de vergunning de vergunninghouder in beginsel gerechtigd maakt tot het gebruik ervan en dat het weigeren van de privaatrechtelijke toestemming misbruik van bevoegdheid oplevert tenzij er sprake is van zwaarwegende belangen. ${ }^{6}$ De vraag is nu of als de privaat-

92 Geeft de wettekst zelf een uitdrukkelijk antwoord op de vraag of er ruimte is voor de privaatrechtelijke weg (de 'voorvraag') dan wordt de doorkruisingsformule ook niet toegepast, zie paragraaf 2.3.

93 HR 7 april 2000, AB 2000/438 m.nt. Th.G. Drupsteen (Parkeerexploitatie Amsterdam).

94 Vgl. HR I7 januari I94I, NJ I94I/644 m.nt. P. Scholten, AB Klassiek 2003/7 m.nt. H.Ph.J.A.M. Hennekens (Parlevinker).

95 HR 9 november 20I2, AB 2013/I m.nt. A.H.J. Hofman \& G.A. van der Veen (Hoogheemraadschap/ Götte).

96 HR 5 juni 2009, AB 2009/327 m.nt. G.A. van der Veen, Gst. 2009 (7324), nr. 98 m.nt. J.A.E. van der Does \& P.J. Huisman, JB 2009/I7I m.nt. J.A.F. Peters (Amsterdam/Geschiere). 
rechtelijke toestemming niet wordt geweigerd maar onder (financiële) voorwaarden wordt verleend, dit eveneens misbruik van bevoegdheid kan opleveren. Uit het arrest Hoogheemraadschap/Götte volgt dat de Hoge Raad, ook na het arrest Amsterdam/ Geschiere, is blijven vasthouden aan zijn rechtspraak dat in aanvulling op een publiekrechtelijke toestemming via het privaatrecht een financiële tegenprestatie mag worden bedongen. Het komt ons voor dat het via het privaatrecht vragen van een financiële vergoeding voor bijzonder gebruik op zichzelf geen misbruik van bevoegdheid oplevert in de zin van art. 3:13 BW. Dit kan echter anders liggen wanneer de gevraagde vergoeding onevenredig hoog is, dat wil zeggen zodanig hoog is dat het gebruik waarvoor publiekrechtelijke toestemming wordt gegeven in feite onmogelijk wordt. ${ }^{77}$ De gerechtigdheid tot het gebruik van de publiekrechtelijke vergunning, die de Hoge Raad uitdrukkelijk tot uitgangspunt heeft genomen, gaat derhalve niet zo ver dat de privaatrechtelijke toestemming om niet moet worden verleend.

Voor de goede orde, in aansluiting op onze afwijzing van het onderscheid tussen beleidsmatige en beleidsneutrale privaatrechtelijke overheidsovereenkomsten (paragraaf 3.3): het is niet uitgesloten dat de doorkruisingsformule ook van toepassing is op de privaatrechtelijke overeenkomsten die in de literatuur als beleidsneutrale overeenkomsten worden bestempeld. Belangrijker nog is dat, zoals hier bleek, het evenmin is uitgesloten dat de doorkruisingsformule niet wordt toegepast op overeenkomsten die een beleidsmatig karakter dragen. Voor de toepasselijkheid van de doorkruisingsformule is immers slechts bepalend of aan de overheid bij een publiekrechtelijke regeling ter behartiging van zekere belangen bepaalde bevoegdheden zijn toegekend. $9^{8}$

\subsection{Bevoegdhedenovereenkomsten}

\section{Geïmpliceerde bevoegdheid}

Naar geldend recht zijn overeenkomsten waarin de overheid afspreekt hoe zij een publiekrechtelijke bevoegdheid in de toekomst zal gaan uitoefenen, in beginsel toegestaan. Dit blijkt al uit de rechtspraak van decennia geleden. ${ }^{99}$

Hiervoor, in paragraaf 3.4, werd reeds aangestipt dat het in verschillende rechtsstelsels niet steeds vanzelfsprekend wordt geacht dat een bestuursorgaan over de hem toegekende publiekrechtelijke bevoegdheden overeenkomsten kan sluiten. Dat hangt samen met de wijze waarop in een rechtsstelsel wordt aangekeken tegen de verhouding tussen uitdrukkelijke en geïmpliceerde bevoegdheden. De bevoegdheid om bevoegdhedenovereenkomsten te sluiten kan naar Nederlands recht het best worden begrepen als een geïmpliceerde bevoegdheid. De specifieke wettelijke toekenning van een publiekrechtelijke bevoegdheid aan een bestuursorgaan (door middel van attributie of delegatie) schept in beginsel de ruimte voor het bestuursorgaan om over het

Vgl. A.H.J. Hofman, 'Vergoedingen voor het gebruik van overheidseigendommen: een uitweg door het doorkruisingslabyrint?', TBR 2014/92, p. 504.

98 Zie uitdrukkelijk in deze zin HR 26 januari I990, NJ I991/393, AB I99o/408 m.nt. G.P. Kleijn, AB Klassiek 2009/I5 m.nt. H.Ph.J.A.M. Hennekens (Windmill).

99 HR I3 april I962, ARB I962, p. 487 m.nt. J.R. Stellinga, AB Klassiek 2003/9 m.nt. D.A. Lubach (Kruseman) en HR 4 januari $1_{963}$, ARB I963/603 m.nt. J.R. Stellinga (Landsmeer). 
gebruik van die bevoegdheid een overeenkomst te sluiten. Ofschoon een bevoegdhedenovereenkomst een heel enkele keer over een afzonderlijke en expliciete wettelijke grondslag beschikt waarin uitdrukkelijk blijkt dat deze overeenkomst kan worden gesloten (zie bijvoorbeeld de Wet gemeenschappelijke regelingen, waarin een grondslag is neergelegd om (onder meer) bevoegdhedenovereenkomsten te sluiten), is in beginsel een zo ver strekkende wettelijke grondslag derhalve niet vereist. Wanneer in een rechtsstelsel het legaliteitsbeginsel zo wordt begrepen dat er geen plaats is voor geïmpliceerde bevoegdheden, is er a fortiori geen ruimte voor het onderkennen van de rechtsfiguur van de bevoegdhedenovereenkomst.

De geïmpliceerde bevoegdheid is in het bestuursrecht een wat minder onderkende rechtsfiguur, daarom is het wellicht goed te vermelden dat de bevoegdheid om dergelijke overeenkomsten te sluiten niet de enige geïmpliceerde bevoegdheid is die ons bestuursrecht kent. Te denken valt voorts aan de bevoegdheid om over het gebruik van die publiekrechtelijke bevoegdheid toezeggingen te doen of beleidsregels vast te stellen. De bevoegdheid om beleidsregels vast te stellen kent overigens een eigen algemene regeling in de Awb (titel 4.3); voor de geïmpliceerde bevoegdheden om toezeggingen te doen en een bevoegdhedenovereenkomst te sluiten is dat (nog?) niet het geval. ${ }^{100}$

Het geïmpliceerde karakter van deze bevoegdheid is een principiële kwestie. Juist hier blijkt waarom het naar onze mening minder gelukkig is een bevoegdhedenovereenkomst op te vatten als een privaatrechtelijke overeenkomst: een privaatrechtelijke titel ontbreekt.

Dat de mogelijkheid bestaat om bevoegdhedenovereenkomsten te sluiten neemt uiteraard niet weg dat de ruimte die daarvoor bestaat, begrensd is. Voor het in kaart brengen van die ruimte is het zinvol te onderscheiden tussen het maken van contractuele afspraken over de toekomstige invulling van een publiekrechtelijke bevoegdheid enerzijds en de verplichtingen die de wederpartij van de overheid op zich neemt anderzijds. Afzonderlijk punt van aandacht vormt de vraag of belangen van derden, meer in het bijzonder derden-belanghebbenden bij het besluit ter uitvoering van de overeenkomst, de ruimte om te contracteren kunnen beperken.

\section{De bevoegdheid om te contracteren}

Of het mogelijk is om te contracteren over een publiekrechtelijke bevoegdheid hangt af van de ruimte die de overheid heeft om die bevoegdheid zelf in te vullen. Laat de wet bij het uitoefenen van een publiekrechtelijke bevoegdheid het bestuur beslissingsruimte, dan kan over deze ruimte worden gecontracteerd. Uiteraard heeft het bestuur die ruimte wanneer er veel vrijheid is om een eigen belangenafweging te maken, zoals bij planologische bevoegdheden.

Anders dan wel werd en ten onrechte soms nog wordt gedacht, ${ }^{\text {ior }}$ is het voor het bestuur ook mogelijk om in gevallen dat er geen sprake is van beleidsvrijheid,

\footnotetext{
Ioo Zie uitvoerig over geïmpliceerde bevoegdheden: F.J. van Ommeren, 'Het legaliteitsbeginsel in het staats- en bestuursrecht: opkomst en ondergang van de geïmpliceerde bevoegdheden?', RM Themis 2002, p. I23 e.v. en Van Wijk/Konijnenbelt \& Van Male 20I4, p. I2I.

IOI Waarover: Van Wijk/Konijnenbelt \& Van Male 20I4, p. 244, 245.
} 
overeenkomsten over het gebruik van de publiekrechtelijke bevoegdheid te sluiten. Het gaat dan met name om de invulling van door de wet gelaten interpretatieruimte, zoals bij de uitleg van wettelijke voorschriften en de interpretatie bij de vaststelling van feitelijke omstandigheden. Zo laat de belastingwet- en regelgeving de belastinginspecteur louter dergelijke interpretatieruimte. Dit staat er evenwel niet aan in de weg dat er op dit terrein bevoegdhedenovereenkomsten - met andere woorden: fiscale vaststellingsovereenkomsten - kunnen worden gesloten, mits de fiscus blijft binnen de kaders van zijn interpretatieruimte. ${ }^{\mathrm{IO}}$

Heeft het bestuur met betrekking tot de uitoefening van een bepaalde publiekrechtelijke bevoegdheid geen enkele vorm van beslissingsruimte, dan is het niet mogelijk daarover te contracteren; gebeurt dit wel, dan is de overeenkomst nietig.

Volledigheidshalve zij opgemerkt dat het sluiten van een bevoegdhedenovereenkomst uiteraard voorts niet tot de mogelijkheden behoort wanneer de wet deze weg uitdrukkelijk afsnijdt. Art. I22 Woningwet bijvoorbeeld bepaalt uitdrukkelijk dat geen 'rechtshandelingen naar burgerlijk recht' kunnen worden verricht. Aangezien in wetgeving en rechtspraak alle overeenkomsten, met inbegrip van de bevoegdhedenovereenkomst, als privaatrechtelijk worden aangemerkt, betekent dit dat een bevoegdhedenovereenkomst over de betrokken publiekrechtelijke bevoegdheden niet geoorloofd is. ${ }^{103}$

\section{Aanvaardbaarheid contractuele verplichtingen wederpartij}

Wanneer over een publiekrechtelijke bevoegdheid wordt gecontracteerd, ligt het in de rede dat in de overeenkomst bedingen worden opgenomen met verplichtingen voor de wederpartij. Vaak zwijgt de wet over de geoorloofdheid van dit soort bedingen. Soms laat de wet zich hier wel over uit; zo valt te wijzen op art. 6.4a Wet ruimtelijke ordening, op grond waarvan planschadevergoedingsbedingen kunnen worden opgenomen in een (bevoegdheden)overeenkomst. Voor de toelaatbaarheid van het opnemen van dit soort bedingen kijken wij nu met name naar de betekenis van de wettelijke voorschriften, de doorkruisingsformule en de algemene beginselen van behoorlijk bestuur.

In algemene zin verzet het legaliteitsbeginsel zich niet tegen het opnemen van verplichtingen voor de wederpartij van de overheid in bevoegdhedenovereenkomsten. Dit hoeft in zoverre niet te verwonderen dat het legaliteitsbeginsel vooral betrekking heeft op het eenzijdig opleggen van verplichtingen. ${ }^{\mathrm{IO}}{ }^{\text {Worden }}$ de verplichtingen door de wederpartij aanvaard, dan biedt de wederzijdse instemming in beginsel voldoende legitimatie jegens de wederpartij. Een specifieke wettelijke voorziening is voor deze overeenkomst niet nodig. Een goed voorbeeld vormt de fiscale vaststellingovereenkomst. In dit soort overeenkomsten spreekt de Belastingdienst met een belastingplichtige af hoe de interpretatieruimte die de wet laat,

I02 Zie uitvoerig over fiscale vaststellingsovereenkomsten: P.J. Huisman, De fiscale vaststellingsovereenkomst, Deventer: Kluwer 20I3b.

I03 Zie HR 4 april 2003, AB 2004/60 m.nt. G.A. van der Veen en HR I7 juni 20II, AB 20II/330 m.nt. F.J. van Ommeren (Van Sundert/Breda). Vgl. hetgeen is opgemerkt in paragrafen 2.3 en 3.6.

I04 F.J. van Ommeren, De verplichting verankerd. De reikwijdte van het legaliteitsbeginsel en het materiële wetsbegrip (diss. Amsterdam VU), Zwolle: W.E.J. Tjeenk Willink I996, p. 62, $35^{8}$. 
wordt ingevuld bij het opleggen van een aanslag; beide partijen conformeren zich hieraan en zijn gebonden aan de gemaakte afspraken.

De aanvaarding van de overeenkomst biedt echter niet steeds voldoende legitimatie. Er zijn situaties waarin de wet de sterke positie van de overheid dient te compenseren door de burger als wederpartij (aanvullende) waarborgen te bieden. Derhalve mogen bepaalde contractuele verplichtingen niet worden aangegaan zonder dat er een specifieke wettelijke voorziening is die deze waarborgen biedt. Dit blijkt ook uit de jurisprudentie.

Of voor het opnemen van een bepaald beding in een bevoegdhedenovereenkomst een specifieke wettelijke titel is vereist, hangt in het bijzonder af van het wettelijk kader dat ten grondslag ligt aan de publiekrechtelijke bevoegdheid waarover wordt gecontracteerd en van het oogmerk waarvoor het in het leven is geroepen. Dit kan goed worden geïllustreerd aan de hand van het vrij recente arrest over de Ruimte voor Ruimte-overeenkomst. ${ }^{105}$ Kort gezegd, heeft dit arrest betrekking op een bevoegdhedenovereenkomst waarin de gemeente de wederpartij een betalingsverplichting oplegt voor het verkrijgen van een vrijstelling van een bestemmingsplan ten behoeve van de bouw van een woning (zie art. I9 Wet op de Ruimtelijke Ordening (oud)). De overeenkomst is aangegaan in het kader van de zogeheten 'Ruimte voor ruimte'-regeling (ook wel: RvR-regeling). De gemeentelijke vordering tot nakoming van deze betalingsverplichting wordt echter tot in de hoogste instantie afgewezen. Het ontkennende antwoord op de vraag of de gemeente hier de ruimte had om een financiële bijdrage te bedingen, werd door het hof in het bijzonder gebaseerd op eerdere jurisprudentie van de Hoge Raad. Uit die rechtspraak bleek reeds dat in het kader van de ruimtelijke ordening in beginsel uitsluitend wanneer de wet daarvoor een voorziening bevatte een financiële bijdrage in de kosten kon worden gevraagd. ${ }^{\text {106 }}$

De ruimte om een financiële bijdrage te bedingen speelde eerder onder meer in het arrest Nunspeet/Mulder, alwaar het meer specifiek ging om de geoorloofdheid van een overeenkomst tot planschadekostenverhaal. ${ }^{107}$ Het negatieve antwoord dat de Hoge Raad in dat arrest gaf, vormde voor de wetgever zelfs aanleiding tot ingrijpen. Met behulp van een spoedwet werd er een wettelijke grondslag gecreëerd voor verhaal van planschadevergoeding via een overeenkomst (art. 49a WRO (oud)). In de opvolger van de WRO, de Wet ruimtelijke ordening, is deze bepaling overgenomen (zie het eerder genoemde art. 6.4a Wro).

Teneinde meer inzicht te verkrijgen in de maatstaven waarmee de ruimte om een bevoegdhedenovereenkomst aan te gaan moet worden beoordeeld, zijn zowel het arrest Ruimte voor Ruimte als het arrest Nunspeet/Mulder zeer van belang. In beide

I05 HR I4 juni 20I3, AB 20I3/273 m.nt. F.J. van Ommeren \& G.A. van der Veen, O\&A 20I3/90 m.nt. P.J. Huisman ('Ruimte voor Ruimte'-overeenkomst).

Io6 In deze jurisprudentie staat (onder meer) een analyse van de WRO(oud) centraal. In de thans geldende Wet ruimtelijke ordening is het uitgangspunt contractsvrijheid. Dit betekent echter niet dat het publiekrecht de ruimte om te contracteren niet meer zou begrenzen; zie bijvoorbeeld art. 3:I4 BW en art. 3:I lid 2 Awb. Het is, ook onder het nieuwe wettelijke regime, zelfs de vraag of er via de privaatrechtelijke weg meer ruimte is om kosten te verhalen dan via de publiekrechtelijke weg. Zie hierover nader J. Struiksma, 'Contractsvrijheid door de Grondexploitatiewet?', WPNR 2006, p. 82 I e.v.; Groen 20I4, p. 36r e.v., 369 e.v. en 389 e.v. en P.J.J. van Buuren e.a., Hoofdlijnen ruimtelijk bestuursrecht, Deventer: Kluwer 2014 e.a., p. 231.

I07 HR 2 mei 2003, AB 2003/354 m.nt. E.W.J. de Groot \& G.A. van der Veen (Nunspeet/Mulder). 
arresten stelde de lagere rechter uitdrukkelijk de vraag aan de orde in hoeverre de financiële verplichting een onaanvaardbare doorkruising oplevert van het wettelijke stelsel. In het oog springt dat de Hoge Raad daarentegen deze formule niet expliciet toepast. Wel kunnen, vooral in het arrest Nunspeet/Mulder, met niet al te veel moeite de eerste twee ijkpunten van de doorkruisingsformule in de overwegingen van de Hoge Raad worden ingelezen - de Hoge Raad slaat acht op de inhoud en strekking van de wet en de daarmee verband houdende belangen van de burger maar noodzakelijk is dit niet. Dit geeft voedsel aan de gedachte dat in de ogen van de Hoge Raad de doorkruisingsformule bij bevoegdhedenovereenkomsten niet aan de orde is. Wij komen zo apart terug op de vraag of de doorkruisingsformule wel de meest geschikte maatstaf is om de toelaatbaarheid van dit type (contractuele) bedingen te beoordelen (zie het slot van deze paragraaf).

Ook de algemene beginselen van behoorlijk bestuur begrenzen de toelaatbaarheid van de verplichtingen die de overheid via een bevoegdhedenovereenkomst bedingt. Daarbij is er wederom een sterke samenhang tussen het wettelijke kader dat de publiekrechtelijke bevoegdheid verschaft en de toelaatbaarheid van specifieke bedingen in een overeenkomst. Zo is een contractuele verplichting in strijd met het verbod op détournement de pouvoir (art. 3:3 Awb) nietig. ${ }^{108}$ Bedingt de overheid een bepaalde prestatie van de burger, dan dient deze prestatie samen te hangen met het doel van de bestuursbevoegdheid waarover een afspraak wordt gemaakt. Dit blijkt duidelijk uit het arrest Alkemade/Hornkamp en is recentelijk eveneens tot uitdrukking gebracht in het arrest 'Ruimte voor Ruimte'-overeenkomst. ${ }^{109}$ Een publiekrechtelijke bevoegdheid mag niet voor een ander doel worden gebruikt dan waarvoor zij is gegeven; hetgeen ook geldt voor overeenkomsten waarin over deze bevoegdheid is gecontracteerd.

\section{Bevoegdhedenovereenkomst en derden}

De uitvoering van een bevoegdhedenovereenkomst bestaat aan overheidszijde doorgaans uit het nemen van besluiten in de zin van de Awb. Bij deze besluiten kunnen de belangen van derden (niet contractspartijen) een belangrijke positie innemen; het niet meenemen van deze belangen bij de besluitvorming dan wel het veronachtzamen daarvan kan leiden tot een vernietiging van het uitvoeringsbesluit door de bestuursrechter. Juridisch gezien is de positie van een derde niet anders bij een besluit ter uitvoering van een bevoegdhedenovereenkomst dan bij een 'gewoon' besluit; heeft hij een stevige positie bij een besluit, dan behoudt hij deze. De feitelijke positie van de derde kan daarentegen wel degelijk sterk verzwakt zijn, aangezien de contractspartijen, buiten de derde om, overeenstemming (commitment!) hebben, waardoor het voor hem moeilijker kan zijn om via zijn wettelijk gegarandeerde positie in de fase van de besluitvorming het tij nog te keren. ${ }^{\text {IIo }}$ Een (wettelijke) verplichting om bepaalde derden reeds bij de totstandkoming van de overeenkomst te betrekken en van een eenmaal gesloten contract op de hoogte te brengen is er

Io8 HR 3 april I998, AB I998/24I m.nt. Th.G. Drupsteen (Alkemade/Hornkamp) en HR I4 juni 20I3, AB 2013/273 m.nt. F.J. van Ommeren \& G.A. van der Veen, O\&A 2013/90 m.nt. P.J. Huisman ('Ruimte voor Ruimte'-overeenkomst).

Io9 HR 3 april I998, AB I998/24I m.nt. Th.G. Drupsteen (Alkemade/Hornkamp).

IIo Zie ook Lubach I982, p. 177. 
in beginsel niet. Hoewel (op papier) de positie van derden bij de besluitvorming verzwakt kan zijn, lijkt het naar geldend recht echter niet zo te zijn dat de bezwaren van derden kunnen leiden tot nietigheid of vernietiging van de bevoegdhedenovereenkomst. In zoverre beperken derden de ruimte om te kunnen contracteren niet.

Vanwege hun feitelijk verzwakte positie rijst de vraag of het wenselijk is om de positie van derden bij bevoegdhedenovereenkomsten en de uitvoering daarvan toch ook juridisch te verstevigen. Wij zijn geneigd die vraag bevestigend te beantwoorden. Dit is te realiseren door bij de totstandkoming en de bekendmaking van zowel de overeenkomst als het uitvoeringsbesluit dezelfde soort waarborgen voor derdenbelanghebbenden te verlangen. Concreet betekent dit dat in die gevallen dat een derde bij de besluitvorming gehoord dient te worden en van het besluit op de hoogte dient te worden gebracht, hij ook reeds bij het aangaan van de overeenkomst moet worden gehoord en van de overeenkomst in kennis moet worden gesteld. Het is uiteraard niet zinvol dit voor iedere bevoegdhedenovereenkomst te vereisen, maar uitsluitend als zij wordt gesloten op een terrein waar derden-belanghebbenden een grote rol spelen. Weliswaar zal zulks tot enige verzwaring van de totstandkomingsprocedure van de overeenkomst kunnen leiden, maar daar staat tegenover dat in de uitvoeringsfase (met andere woorden: de besluitvormingsfase) deze waarborgen toch ook in acht zouden moeten worden genomen. Aldus kunnen de belangen van derden reeds in deze eerdere fase worden gewaarborgd. ${ }^{\text {III }}$

Her(r)ijking van de beoordelingsmaatstaven?

Hiervoor bleek dat de tweewegenleer met de doorkruisingsformule zoals die in het Windmill-arrest tot uitdrukking komt, door de Hoge Raad niet uitdrukkelijk op bevoegdhedenovereenkomsten wordt toegepast. Het blijkt dat vooral het wettelijk kader van de publiekrechtelijke bevoegdheid, met inbegrip van het oogmerk ervan, dominant is voor de vaststelling van de toelaatbaarheid van dit soort overeenkomsten. Verder blijkt er al met al geen duidelijke algemene maatstaf te zijn aan de hand waarvan de geldigheid van contractuele bedingen waarin verplichtingen van de wederpartij van de overheid zijn opgenomen, wordt beoordeeld. Het komt steeds aan op ad hoc beoordelingen van aan de rechter voorgelegde specifieke bedingen, waarbij wordt geredeneerd via de band van het legaliteitsbeginsel, de leer van de onaanvaardbare doorkruising of de algemene beginselen van behoorlijk bestuur. Het ontbreken van een algemene maatstaf is bezwaarlijk vanuit een oogpunt van rechtszekerheid. Het belemmert mogelijk ook de verdere ontwikkeling van de figuur van de bevoegdhedenovereenkomst. In de literatuur is er bovendien op gewezen dat vanwege het publiekrechtelijke karakter het niet voor de hand ligt de tweewegenleer op de bevoegdhedenovereenkomst toe te passen. ${ }^{\mathrm{II}}$

Gezien het voorgaande spreekt het ons meer aan om aan te knopen bij reeds ontwikkelde algemene publiekrechtelijke maatstaven, met name omdat, zoals we hiervoor hebben gezien, de toelaatbaarheid van bevoegdhedenovereenkomsten primair

III Denkbaar is dat deze eisen in een algemene wettelijke regeling als de Awb worden vastgelegd. Zie: Van Ommeren 20Io, p. 725-727 en Huisman 2012, p. 645-651, 685-686 en 687.

II2 Scheltema \& Scheltema 20I3, p. 272. 
wordt bepaald door het wettelijk kader van de regeling waarin de publiekrechtelijke bevoegdheid waarover gecontracteerd wordt staat. De grenzen die gelden voor de publiekrechtelijke bevoegdheidsuitoefening zijn daarmee tevens grenzen voor het contracteren over deze bevoegdheid (men zie de hiervoor besproken arresten Nunspeet/Mulder, Alkemade/Hornkamp en 'Ruimte voor Ruimte'-overeenkomst). Als de wet limitatief regelt welke voorschriften dan wel voorwaarden aan een besluit kunnen worden verbonden, ligt het in de rede dat daaraan niet bij bevoegdhedenovereenkomst voorbij kan worden gegaan. Maar ook als de wettelijke regeling ruimte laat, is deze ruimte niet onbegrensd. Voorschriften en voorwaarden bij een besluit dienen te passen binnen het wettelijke systeem en dienen verband te houden met het doel van de uit te oefenen publiekrechtelijke bevoegdheid. Ook in deze situatie ligt het naar onze mening voor de hand dat aan deze grenzen bij bevoegdhedenovereenkomst niet voorbij kan worden gegaan, en dat dezelfde maatstaven gehanteerd dienen te worden.

Het voorgaande kan geïllustreerd worden aan de hand van de mogelijkheden om financiële voorwaarden aan een beschikking te verbinden. In het bijzonder is de uitspraak Rabobank Stompwijk-Zoeterwoude relevant. De bestuursrechter formuleert hierin criteria die aangeven wanneer het is toegestaan om een financiële voorwaarde aan een beschikking te verbinden in het geval de wet dit niet uitdrukkelijk toestaat of verbiedt. Een dergelijke voorwaarde is toegestaan, mits:

I. door voldoening aan de voorwaarde een rechtstreekse bijdrage wordt geleverd aan het doel van de publiekrechtelijke regeling waarop de beschikking is gebaseerd,

2. de verlening van de beschikking in het algemeen belang tot heffing van een geldbedrag noopt, en

3. er niet een andere, in het licht van de rechtsbescherming meer aanvaardbare mogelijkheid is om een tegemoetkoming te verlangen. ${ }^{\mathrm{II} 3}$

Deze drie eisen zijn belangrijk. Het eerste vereiste sluit goed aan bij het verbod van détournement de pouvoir (zie art. 3:3 Awb) en het daarmee verband houdende specialiteitsbeginsel, dat aldus ook voor het verbinden van financiële voorwaarden geldt. De financiële voorwaarde moet doelgebonden zijn, dat wil zeggen passen bij het doel of oogmerk van de wet, of preciezer nog: passen bij het doel waarvoor de beschikking wordt verleend. Het tweede vereiste ligt publiekrechtelijk gezien voor de hand. Het bestuursorgaan mag niet 'zomaar' om een willekeurige reden geld heffen, maar het algemeen belang moet de heffing nodig maken. Dit vereiste is in de latere jurisprudentie van de Afdeling bestuursrechtspraak van de Raad van State ook wel preciezer geformuleerd, namelijk als de eis dat de omvang van de betalingsverplichting direct gerelateerd moet zijn aan de aantasting van de wettelijke

II3 ARRvS 30 augustus I985, AB I986/243 m.nt. D.A. Lubach (Rabobank Stompwijk-Zoeterwoude). Zie ook ABRvS I februari 1995, Gst. I995 (70I3), nr. 8 m.nt. C.P.J. Goorden (kapvergunning Bussum), ABRvS 4 augustus I998, JB I998/2I8 m.nt. H.J. Simon (Parkeerfonds Schagen), ABRvS I3 juni 2000, AB 2000/3I5 m.nt. N. Verheij (woonruimteonttrekking Arnhem), ABRvS 27 september 2006, Gst. 2007 (7272), nr. 50 (parkeercompensatie Deventer) en ABRvS 25 oktober 2006, Gst. 2007 (7272), nr. 5I (Parkeereis Goudse prostitutie-inrichting). 
doelstelling, die door de vergunde activiteit wordt bewerkstelligd. ${ }^{114}$ Het krijgt daarmee tevens het karakter van een evenredigheidseis (vgl. art. 3:4 lid 2 Awb). Ook dit vereiste kan trouwens vrij gemakkelijk meer of minder streng worden uitgelegd. Ten slotte wordt acht geslagen op de mate van rechtsbescherming. Op basis van de jurisprudentie van de bestuursrechter biedt dit een aantrekkelijk algemeen publiekrechtelijk toetsingskader voor de beoordeling van de ruimte voor financiële voorwaarden.

Dit toetsingskader heeft op onderdelen een andere inhoud dan de doorkruisingsformule. Voorop staat het vereiste van de doelgebondenheid, dat meer specifiek is dan het ijkpunt van de inhoud en strekking van de publiekrechtelijke regeling. Het vereiste van het algemeen belang is algemener gesteld dan het ijkpunt van de belangen van de burger. De op evenredigheid gerichte uitwerking ervan is daarentegen juist specifieker. Met het gewicht dat aan de rechtsbescherming wordt toegekend, legt de bestuursrechter de lat hoger dan de burgerlijke rechter doet bij de toepassing van de doorkruisingsformule, want bij de burgerlijke rechter vormt de bestuursrechtelijke rechtsbescherming immers op zichzelf geen doorslaggevend argument. Wellicht komt dat doordat het de bestuursrechter is die deze eisen formuleert?

Voor wat betreft de toelaatbaarheid van financiële bedingen in bevoegdhedenovereenkomsten waarin gecontracteerd wordt over de bevoegdheid een beschikking te nemen, achten wij het wenselijk om aan te sluiten bij dezelfde regels als die voor de toelaatbaarheid van financiële voorwaarden bij beschikkingen zijn geformuleerd. ${ }^{\text {II5 }}$ Een heel grote stap hoeft dit overigens niet te zijn, doordat de burgerlijke rechter ook heeft overwogen dat aan een ontheffing voorschriften kunnen worden verbonden waaronder het betalen van een vergoeding die is gebonden aan het doel van het ontheffingsvereiste. ${ }^{\mathrm{II}}$ Voor wat betreft de toelaatbaarheid van financiële bedingen in een bevoegdhedenovereenkomst is voorts het door ons besproken arrest 'Ruimte voor Ruimte'-overeenkomst reeds een stap in deze richting. ${ }^{\text {II7 }}$ In de lagere civiele jurisprudentie wordt eveneens bij deze bestuursrechtelijke rechtspraak aangesloten. ${ }^{\text {II8 }}$

Door de hier bepleite aansluiting bij de bestuursrechtelijke jurisprudentie komt beter tot uitdrukking dat de toelaatbaarheid van bevoegdhedenovereenkomsten wordt bepaald door het wettelijk kader van de regeling waarin de publiekrechtelijke bevoegdheid staat waarover wordt gecontracteerd. Te verwachten valt dat de rechtszekerheid daardoor zal kunnen worden vergroot. Voordeel is bovendien dat er een meer uniform beoordelingskader ontstaat voor eenzijdige en bij overeen-

II4 Zie bijvoorbeeld ABRvS I februari I995, Gst. I995 (70I3), nr. 8 m.nt. C.P.J. Goorden (kapvergunning Bussum). Daarover: Schlössels \& Zijlstra 20I0, p. 827-828 en Van Wijk/Konijnenbelt \& Van Male 20I4, p. 201.

II5 Zie ook in deze richting Duijkersloot e.a. 20I0, p. 57; Huisman 20I2, p. 65I e.v. en Scheltema \& Scheltema 2013, p. 252.

II6 Zie HR I9 mei 2000, $A B$ 2000/428 m.nt. P.J.J. van Buuren (Haagse Bagger).

II7 HR I4 juni 20I3, AB 20I3/273 m.nt. F.J. van Ommeren \& G.A. van der Veen, O\&A 20I3/90 m.nt. P.J. Huisman ('Ruimte voor Ruimte'-overeenkomst).

II8 In het bijzonder wordt aansluiting gezocht bij hetgeen in ARRvS 4 oktober I985, AB I986/242 m.nt. D.A. Lubach (De Pluimpot B.V./Tholen) is overwogen, zie o.a. Hof 's-Hertogenbosch 27 februari I989, AB I989/563 m.nt. P.J.J. van Buuren en Hof's-Gravenhage 4 februari r999, r.o. 5 in de zaak die leidde tot HR I3 april 200I, AB 2002/315 m.nt. F.J. van Ommeren (Polyproject/Warmond I). 
komst opgelegde financiële voorwaarden. Het is daardoor eveneens duidelijk dat het niet mogelijk is voor de overheid om op grond van een bevoegdhedenovereenkomst meer of een andere vergoeding te vragen dan door het verbinden van een financiële voorwaarde aan een besluit.

\subsection{Uitvoeringsovereenkomsten}

\section{Geïmpliceerde bevoegdheid}

Uitzonderingen daargelaten beschikt de uitvoeringsovereenkomst niet over een specifieke wettelijke grondslag. De bevoegdheid om een uitvoeringsovereenkomst te sluiten vloeit voort uit de bevoegdheid van het bestuursorgaan om een publiekrechtelijke bevoegdheid uit te oefenen. Net als bij de bevoegdhedenovereenkomsten is er sprake van een geïmpliceerde bevoegdheid. Verschil is evenwel, zoals gezegd, dat de uitvoeringsovereenkomst niet aan de uitoefening van de bevoegdheid voorafgaat, maar erop volgt. Uit de wettelijke bevoegdheidsomschrijving blijkt wel dat een publiekrechtelijke bevoegdheid moet worden uitgeoefend en zijn bepaalde in dat kader te verrichten bestuurshandelingen, zoals vergunningverlening, wel uitdrukkelijk genoemd. Maar dat ter uitvoering ook een overeenkomst kan (soms zelfs: moet) worden gesloten, blijkt niet uit de specifieke wettelijke regeling.

Uitvoeringsovereenkomsten komen op diverse terreinen voor. Zo valt onder meer te wijzen op de subsidie-uitvoeringsovereenkomst en de afvalinzamelingsuitvoeringsovereenkomst. De subsidie-uitvoeringsovereenkomst is iets meer uitgekristalliseerd, reden waarom op deze overeenkomst nu eerst wordt ingegaan. Bij wijze van verkenning nemen wij daarna kort de afvalinzamelingsuitvoeringsovereenkomst onder de loep: wat valt daarvan te leren over de figuur van de ongeregelde uitvoeringsovereenkomst?

Een wettelijke uitvoeringsovereenkomst: subsidies

De Awb bevat een regeling over de subsidie-uitvoeringsovereenkomst. Art. 4:36 lid I Awb bepaalt dat ter uitvoering van een beschikking tot subsidieverlening een overeenkomst kan worden gesloten. De reden dat de Awb hiervoor een expliciet voorschrift bevat, is dat de wetgever uitdrukkelijk ruimte wilde bieden voor het gebruik van deze uitvoeringsovereenkomst. Dat werd noodzakelijk geacht in het licht van het feit dat de beschikkinguervangende subsidieovereenkomst nu juist niet (langer) geoorloofd werd geacht. Teneinde te voorkomen dat in het verlengde daarvan in één klap ook uitvoeringsovereenkomsten op dit terrein niet langer meer geoorloofd zouden zijn, werd de figuur van de subsidie-uitvoeringsovereenkomst ingevoerd. ${ }^{\text {Irg }}$ Toen de beschikkingvervangende subsidieovereenkomst nog toelaatbaar werd geacht, bestond aan het uitdrukkelijk onderscheiden van de subsidie-uitvoeringsovereenkomst nog geen behoefte.

II9 PG Awb III, p. I72 e.v. 
Deze overeenkomsten komen vooral voor bij subsidies in de vorm van leningen en garanties; het betreft overeenkomsten van geldlening of van borgtocht. ${ }^{120} \mathrm{De}$ uitvoeringsovereenkomst wordt voorts veel gebruikt om zeker te stellen dat een te subsidiëren activiteit ook daadwerkelijk wordt verricht. Dit kan namelijk niet via het publiekrecht worden afgedwongen. ${ }^{\mathrm{I} 2 \mathrm{I}}$ Art. 4:36 lid 2 Awb regelt met het oog hierop dat in de uitvoeringsovereenkomst kan worden bepaald dat de subsidieontvanger verplicht is de activiteiten te verrichten waarvoor de subsidie is verleend. De nakoming van de contractuele verplichting kan de overheid afdwingen bij de burgerlijke rechter. Dit maakt het zeer aantrekkelijk voor de overheid om deze contracten te sluiten.

Bij het sluiten van subsidie-uitvoeringsovereenkomsten bestaat het risico dat de overheid, de subsidiegever, de regels van de subsidietitel (meer in het bijzonder afd. 4.2.4) van de Awb omzeilt. Dit zou kunnen gebeuren doordat in de overeenkomst bedingen worden opgenomen die niet toelaatbaar zijn als voorschrift of voorwaarde bij een subsidiebeschikking. Wanneer dit zich voordoet levert dit strijd op met de subsidietitel in de Awb; reeds op grond hiervan zijn dergelijke contractuele bedingen niet toelaatbaar en nietig op grond van art. 3:40 lid I BW. Hieruit volgt dat in een uitvoeringsovereenkomst geen bedingen mogen worden opgenomen die in strijd zijn met afd. 4.2.4 Awb. ${ }^{122} \mathrm{Er}$ is een sterke relatie tussen hetgeen toelaatbaar is in het kader van het verbinden van voorschriften aan een subsidiebeschikking en het bedingen van bepaalde prestaties in een uitvoeringsovereenkomst.

Bij uitvoeringsovereenkomsten speelt daarnaast de specifieke vraag wat de gevolgen zijn van de intrekking door het bestuur dan wel een vernietiging door de bestuursrechter van een (subsidie)beschikking waarvan de overeenkomst een uitvoering vormt. De Awb bevat ter zake geen regeling.

Voor wat betreft de intrekking van de verleningsbeschikking en de gevolgen voor de overeenkomst is art. 6:229 BW relevant. ${ }^{123}$ Een overeenkomst die de strekking heeft voort te bouwen op een reeds tussen partijen bestaande rechtsverhouding, is, zo bepaalt dit artikel, vernietigbaar indien deze rechtsverhouding ontbreekt, tenzij dit in verband met de aard van de overeenkomst, de in het verkeer geldende opvattingen of de omstandigheden van het geval voor rekening behoort te blijven van degene die zich op dit ontbreken beroept. Valt de verleningsbeschikking weg, dan kan dit dus tot vernietigbaarheid leiden van de uitvoeringsovereenkomst. Trekt het bestuur de beschikking in op grond van verwijtbaar gedrag van de subsidieontvanger, dan is de overeenkomst ook vernietigbaar. Heeft het bestuur ingetrokken omdat de beschikking onjuist is, dan is het te verdedigen dat de gevolgen van de

I20 PG Awb III, p. I72 en p. 224, 225.

I2I Er zijn overigens wel bestuursrechtelijke sancties op het niet verrichten van een activiteit. Zo kan gedacht worden aan de intrekking van de beschikking. Daarmee kan echter niet worden afgedwongen dat de activiteit wordt verricht. De dreiging van een intrekking kan de subsidieontvanger er evenwel mogelijk toe bewegen toch te handelen.

I22 Zie ook M.J. Jacobs \& W. den Ouden, 'Hoedt u voor artikel 4:36 Awb. Problemen rond het gebruik van uitvoeringsovereenkomsten bij subsidieverstrekking', NTB I997, p. 257-258 en W. den Ouden, M.J. Jacobs \& N. Verheij, Subsidierecht (Mastermonografieën Staats- en bestuursrecht), Deventer: Kluwer 20II, p. I63.

I23 NV II, PG Awb III, p. I78. Zie reeds G.R.J. de Groot, B.M.J. van der Meulen \& A.A. van Rossum, 'Subsidies, beleidsregels, bestuursorganen. Het wetsvoorstel derde tranche van de Algemene wet bestuursrecht', NJB I994, p. II94. 
intrekking voor rekening van het bestuur horen te blijven, en dat de overeenkomst niet vernietigbaar is. ${ }^{124}$

Wordt de onderliggende subsidieverleningsbeschikking vernietigd op grond van het beroep van de subsidieontvanger, omdat hij het niet eens is met de hoogte van de subsidie of de verplichtingen in de beschikking, dan is het aan het bestuur om een nieuwe beschikking te nemen, waarbij het voor partijen mogelijk is om desgewenst de overeenkomst aan te passen. ${ }^{125}$ Vindt vernietiging plaats op grond van het beroep van een derde, hetgeen niet veel voorkomt, dan ligt het anders. Ingeval van vernietiging van de beschikking vanwege een formeel gebrek is het mogelijk dat het gebrek wordt hersteld; in deze situatie heeft dat geen gevolgen voor het contract. Gaat het om een vernietiging wegens een materieel gebrek, dan betekent dit dat de beschikking niet zo had mogen worden gegeven, hetgeen voor de overeenkomst tot gevolg heeft dat deze niet of niet verder uitgevoerd mag worden. Dit leidt eventueel tot een schadevergoedingsverplichting van de subsidiegever (de overheid) jegens de subsidieontvanger. ${ }^{126}$

Een complicerende factor is dat de verleningsbeschikking wordt gevolgd door een subsidievaststellingsbeschikking. Wat de gevolgen zijn van de intrekking en de vernietiging van deze beschikking voor de uitvoeringsovereenkomst is niet geheel duidelijk. ${ }^{127}$

\section{Buitenwettelijke uitvoeringsovereenkomst: afualinzameling}

De subsidie-uitvoeringsovereenkomst heeft een specifieke wettelijke grondslag. Doorgaans is er echter voor de uitvoeringsovereenkomst geen specifieke wettelijke voorziening. De bevoegdheid om een afvalinzamelingsuitvoeringsovereenkomst te sluiten voor de inzameling van huishoudelijke afvalstoffen vloeit voort uit de bevoegdheid om ter zake een aanwijzingsbesluit te nemen. ${ }^{128}$ De reden dat na het nemen van dit besluit nog een overeenkomst noodzakelijk is, is dat de geadresseerde niet verplicht is om daaraan uitvoering te geven. ${ }^{129}$ Het besluit schept (slechts) het recht dit te doen, niet de verplichting. Hoewel de aanduiding 'aanwijzing' en de tekst van de verordening naar de letter anders suggereren, behelst deze aanwijzing niet meer dan een soort van vergunning (recht) en geen eenzijdige opdracht om zulks te doen. ${ }^{\mathrm{I}{ }^{\circ}}$ Dit komt doordat de wettelijke regeling het gemeentebestuur niet

I24 Den Ouden, Jacobs \& Verheij 20II, p. I68. Zie ook NV II, PG Awb III, p. I78.

I25 NV II, PG Awb III, p. I78.

I26 NV II, PG Awb III, p. I78.

I27 Den Ouden, Jacobs \& Verheij 20II, p. I68-I69 stellen in dit verband dat het, om problemen te voorkomen, raadzaam is om in de uitvoeringsovereenkomst bepalingen op te nemen over de status van de overeenkomst na een eventuele intrekking of vernietiging van de vaststellingsbeschikking.

I28 Zie de ingevolge art. I0.23 Wet milieubeheer vereiste afvalstoffenverordening; art. I0.24 Wm stelt daaraan enige (minimum)eisen. De VNG heeft hiervoor een modelverordening opgesteld. In 2008 is het model geheel herzien en vereenvoudigd.

I29 Zie voor het navolgende reeds: F.J. van Ommeren \& J. Vermont, 'Uit-, aan- en inbesteden in publiek- en privaatrecht. De uitbesteding van het recht om huishoudelijk afval in te zamelen', Gst. 2007 (7266), nr. 7, p. 32- 33.

I30 Art. 2 lid I van de VNG-Afvalstoffenverordening 2008 luidt: 'Het college wijst de inzamelaar aan, die belast is met het inzamelen van huishoudelijke afvalstoffen.' 
de bevoegdheid geeft een inzamelaar van huishoudelijke afvalstoffen dwingend aan te wijzen. Integendeel, de inzamelaar moet de opdracht accepteren. Het legaliteitsbeginsel biedt niet de ruimte aan het bestuursorgaan zonder adequate wettelijke grondslag de inzamelaar deze verplichting op te leggen. De aanvaarding van dit recht biedt daarvoor wel voldoende legitimatie. Daarvoor dient de overeenkomst. Door het sluiten van de overeenkomst verzekert de gemeente zich er bovendien van dat de afvalinzamelaar rechtens verplicht is, in overeenstemming met de overeengekomen voorwaarden, het afval in te zamelen. Bij niet-nakoming heeft de gemeente de mogelijkheid in rechte nakoming te vorderen.

Voor de vraag of en in hoeverre het geoorloofd is deze uitvoeringsovereenkomst te sluiten speelt de doorkruisingsformule geen rol. Voldoende is dat de publiekrechtelijke bevoegdheid deze ruimte laat. Anders gezegd, het is het legaliteitsbeginsel dat hier regeert.

De ruimte om een dergelijke uitvoeringsovereenkomst te sluiten, is aanzienlijk dicht gereguleerd. Het inzamelen van afval is in beginsel een aanbestedingsplichtige dienst. ${ }^{13 \mathrm{I}}$ Dit betekent dat de inzamelovereenkomst in overeenstemming met de regels van het aanbestedingsrecht moet worden gesloten. Het publiekrechtelijke verleningsregime en het regime van het aanbestedingsrecht sluiten niet heel helder op elkaar aan. Zien wij het goed, dan moet in het proces van aanbesteding het nemen van het aanwijzingsbesluit worden beschouwd als het aanbestedingsrechtelijke gunningsbesluit.

Bijzondere aandacht verdient overigens ook de rechtsbescherming tegen uitvoeringsovereenkomsten. Problematisch is niet de rechtsbescherming tegen deze overeenkomst zelf; helder is dat de burgerlijke rechter bevoegd is. Maar minder duidelijk is hoe het zit met de aan het sluiten van de overeenkomst voorafgaande stappen. Ingevolge art. 8:3 lid 2 Awb kan geen beroep worden ingesteld tegen een besluit ter voorbereiding van een privaatrechtelijke rechtshandeling. Met name het gunningsbesluit in een aanbestedingsprocedure is uitgesloten van beroep op de bestuursrechter. ${ }^{132} \mathrm{Wij}$ menen echter dat het nemen van het aanwijzingsbesluit niet onder de reikwijdte van deze uitsluiting valt, aangezien zij niet op de voorbereiding van een privaatrechtelijke rechtshandeling is gericht. ${ }^{133}$ (Hetzelfde geldt overigens voor de subsidieverleningsbeschikking die wordt gevolgd door een subsidie-uitvoeringsovereenkomst: ook die is vatbaar voor bezwaar en beroep.) Maar daarover wordt mogelijk verschillend gedacht. ${ }^{\mathrm{I} 4} \mathrm{Wij}$ laten deze kwestie verder rusten, nu zij niet direct betrekking heeft op de vraag naar de toelaatbaarheid van dit soort overeenkomsten.

I3I De pogingen om deze verplichting via in besteden te omzeilen, laten wij hier terzijde. De Europese rechtspraak laat hiertoe nauwelijks ruimte. Zie Van Ommeren \& Vermont 2007, p. 35, 36.

I32 Ter voorkoming van misverstanden: de Aanbestedingswet 2012 spreekt van 'gunningsbeslissing', daarmee is evenwel niet uitgesloten dat sommige van die beslissingen een besluit in de zin van art. I:3 Awb inhouden.

I33 Ook in de toelichting van de verordening wordt ervan uitgegaan dat het aanwijzingsbesluit vatbaar is voor bezwaar en beroep.

I34 Dit artikel blijkt überhaupt nogal wat vragen op te roepen. Zie m.n. P.J. Huisman \& N. Jak, 'Beslissingen ter voorbereiding van een privaatrechtelijke rechtshandeling van de overheid', JBplus 2008, p. I49 e.v. en 'De twee kanten van artikel 8:3 lid 2 Awb', I. Een privaatrechtelijk besluit (R.J.N. Schlössels) en II. Niet alle besluiten zijn Awb-besluiten (C.N.J. Kortmann), RM Themis 2013, p. $254-258$. 
Het feit dat aan een uitvoeringsovereenkomst (per definitie) de uitoefening van een publiekrechtelijke bevoegdheid voorafgaat, bepaalt mede de positie van derdenbelanghebbenden. Dat bleek hiervoor reeds kort bij de subsidie-uitvoeringsovereenkomst, alwaar niet uitgesloten is dat een derde de verleningsbeschikking in rechte aanvecht, hetgeen bij succes tot gevolg kan hebben dat de uitvoeringsovereenkomst niet kan worden uitgevoerd.

In die gevallen dat op de overheid voor het sluiten van de uitvoeringsovereenkomst een aanbestedingsplicht rust, zijn de belangen van derden in de totstandkomingsfase van de overeenkomst op grond daarvan bijzonder beschermd. Het gaat hier uiteraard om een specifiek soort derden-belanghebbenden, namelijk derden die in beginsel elkaars concurrenten zijn. Oogmerk van het aanbestedingsrecht is immers primair om aan een ieder een gelijke kans te geven om een overeenkomst met de overheid te sluiten. ${ }^{135}$ Uit dit gelijkheidsbeginsel wordt in het aanbestedingsrecht een transparantieverplichting afgeleid. Deze transparantieverplichting is gecodificeerd in art. I.9 en I.I2 lid 2 Aanbestedingswet 20I2. Zij houdt in het bijzonder in dat aan elke potentiële inschrijver een passende mate van openbaarheid dient te worden gegarandeerd.

Niet uit het oog moet worden verloren dat aldus in het aanbestedingsrecht de belangen van derden op een andere wijze worden beschermd dan in het algemene bestuursrecht. Kunnen in het bestuursrecht afzonderlijke derden-belanghebbenden (al dan niet op aanvraag) van nadere informatie worden voorzien of worden gehoord, in het aanbestedingsrecht staat het gelijkheidsbeginsel eraan in de weg dat de één meer of anders wordt behandeld - en dus ook van andere informatie wordt voorzien - dan de ander. De materiële bescherming die het aanbestedingsrechtelijke gelijkheidsbeginsel met zich brengt, is derhalve van andere aard dan die van het gelijkheidsbeginsel als algemeen beginsel van behoorlijk bestuur. ${ }^{136}$ Van de transparantieverplichting staat zelfs nog ter discussie of deze überhaupt wel (al) als een separaat algemeen beginsel van behoorlijk bestuur wordt toegepast. ${ }^{137}$

I35 Zie in meer algemene zin over dit doel en de achterliggende doelen van aanbesteding: E.R. Manunza, 'Naar een consistente en doelmatige regulering van de markt van overheidsopdrachten', in: J.M. Hebly, E.R. Manunza \& M. Scheltema, Beschouwingen naar aanleiding van het wetsvoorstel Aanbestedingswet (preadviezen nr. 38), Den Haag: IBR 20I0, p. 63 e.v., en over de doelstellingen van de Aanbestedingswet 20I2: Van de Meent, Stellingwerff Beintema \& Damsma 2013, p. 244-245 en M.A.B. Chao-Duivis \& R.W.M. Kluitenberg (red.), Parlementaire Geschiedenis Aanbestedingswet 2012, Den Haag: IBR 2013, p. 29 e.v.

I36 Zie voor een meer uitvoerige vergelijking tussen de algemene beginselen van aanbestedingsrecht en de algemene beginselen van behoorlijk bestuur: F.J. van Ommeren, Schaarse vergunningen. De verdeling van schaarse vergunningen als onderdeel van het algemene bestuursrecht (oratie Amsterdam VU), Deventer: Kluwer 2004, p. 44 e.v.

I37 Zie m.n. F.J. van Ommeren, 'Schaarse publieke rechten. Een verplichting tot het creëren van mededingingsruimte?', in: F.J. van Ommeren, W. den Ouden \& C.J. Wolswinkel (red.), Schaarse publieke rechten, Den Haag, Boom Juridische uitgevers 20II, p. 257-259; A. Drahmann, 'Streven naar een transparante (her)verdeling van schaarse publieke rechten', in: F.J. van Ommeren, W. den Ouden \& C.J. Wolswinkel (red.), Schaarse publieke rechten, Den Haag, Boom Juridische uitgevers 20II, p. 267 e.v.; C.J. Wolswinkel, De verdeling van schaarse publiekrechtelijke rechten (diss. Amsterdam VU), Den Haag: Boom Juridische uitgevers 20I3, p. 334 e.v. en A. Drahmann, Transparante en eerlijke verdeling van schaarse besluiten (diss. Leiden), Deventer: Kluwer 2015, p. 359 e.v. 
Voor de bescherming van derden-belanghebbenden bevat de Aanbestedingswet 2012 bijzondere waarborgen, waaronder een zogeheten standstill-termijn, op grond van de Europese rechtspraak ook wel Alcateltermijn genoemd (artikel 2.I27). Deze bepaling brengt met zich dat de aanbestedende dienst een termijn van ten minste 20 dagen moet aanhouden voordat hij de overeenkomst mag sluiten. Oogmerk hiervan is derden de gelegenheid te geven in rechte tegen de gunningsbeslissing op te komen.

Is het al met al bij de bevoegdhedenovereenkomst denkbaar om de positie van derden te versterken door het invoeren van een (vervroegde) informatie- en hoorplicht, ten aanzien van de uitvoeringsovereenkomst heeft de versterking van diens positie plaatsgevonden in het aanbestedingsrecht. Daarbij dient evenwel te worden bedacht dat in het aanbestedingsrecht, met name vanwege de concurrentieverhoudingen en het oogmerk een faire competitie te organiseren, de belangen van derden op een andere wijze worden beschermd dan in het algemene bestuursrecht.

\subsection{Besluitvervangende overeenkomsten}

Besluitvervangende overeenkomsten zijn, zoals gezegd, in ieder geval voor de beantwoording van de vraag of en in hoeverre er ruimte voor het sluiten van dit type overeenkomsten aanwezig is, nader te verdelen in de beschikkingvervangende en de regelvervangende overeenkomsten. Aandachtspunt is - ook hier - in hoeverre de doorkruisingsformule van toepassing is dan wel andere maatstaven voor de beantwoording van deze vraag moeten worden aangelegd.

\section{Beschikkinguervangende overeenkomsten}

De vraag of en in hoeverre beschikkingvervangende overeenkomsten toelaatbaar zijn, is - ondanks dat de Awb een algemene regeling voor het geven van beschikkingen bevat (titel 4.I) - door de wetgever nooit in algemene zin beantwoord. Uit de Awb blijkt niet of en in hoeverre de figuur van de beschikkingvervangende overeenkomst in het algemeen geoorloofd is. Daarvoor is deze regeling te algemeen van aard en opzet, de wetgever heeft zich over deze vraag niet uitdrukkelijk uitgelaten.

Dit ligt anders met de meer uitgewerkte subsidieregeling (titel 4.2 Awb). Tijdens de parlementaire behandeling van de subsidietitel in de Awb is expliciet aan de orde geweest dat beschikkingvervangende subsidieovereenkomsten niet toelaatbaar zijn..$^{13}$ Deze overeenkomsten moeten in beginsel worden beschouwd als een doorkruising van het in de Awb neergelegde stelsel van waarborgen. ${ }^{139}$ Zowel de bestuursrechter als de burgerlijke rechter hebben zich hierbij aangesloten. De Afdeling bestuursrechtspraak van de Raad van State heeft overwogen dat titel 4.2 Awb zich verzet tegen subsidieverlening door middel van een overeenkomst. ${ }^{\mathrm{I}}{ }^{40} \mathrm{In}$ lijn hiermee heeft de Hoge Raad recent geoordeeld dat een overeenkomst niet kan

I38 Zie MvT, PG Awb III, p. I73, NV II, PG Awb III, p. I78 en H II, PG Awb III, p. I82.

I39 Zie ter zake uitvoerig M.J. Jacobs, Subsidieovereenkomsten (diss. Amsterdam VU), Den Haag I999, p. 232 e.v. Zij kan zich niet verenigen met het standpunt dat er (zonder meer) sprake is van een (onaanvaardbare) doorkruising.

I40 ABRvS ig april 2006, AB 2006/296 m.nt. M.J. Jacobs \& W. den Ouden. 
afdoen aan het wettelijke vereiste - zoals dat in de Awb te vinden is - dat de subsidieverlening en -vaststelling bij beschikking plaatsvinden. ${ }^{\mathrm{I} 4 \mathrm{I}}$ Dit betekent dat de beschikkingvervangende subsidieovereenkomst niet geoorloofd is.

Ook op ander terrein wordt de beschikkingvervangende overeenkomst ongeoorloofd geacht. Net als in het subsidierecht is voor rijksbelastingen de beschikkingvervangende overeenkomst niet toegestaan. Er kan wel een (bevoegdheden)overeenkomst (fiscale vaststellingsovereenkomst) worden gesloten over een aanslag, maar die kan niet in plaats van de aanslag komen, want de aanslag moet op een wettelijke grondslag berusten. De overeenkomst kan derhalve niet een alternatief vormen voor de aanslag. ${ }^{\mathrm{I}}{ }^{2}$ De maatstaf om de geoorloofdheid van deze overeenkomst te beoordelen is het legaliteitsbeginsel (in de zin dat de wet de ruimte moet laten om deze overeenkomsten te sluiten). ${ }^{\mathrm{I} 3}$

Van een principiële wenselijkheid dan wel ontoelaatbaarheid van beschikkingvervangende overeenkomsten blijkt verder niet uit de wetgeving. Ook in de bijzondere wet- en regelgeving komt een uitdrukkelijk antwoord - al dan niet in de wetteksten zelf - (vrijwel) niet voor.

Daaraan valt nog wel het een en ander toe te voegen. Hét bezwaar van het gebruik van besluitvervangende overeenkomsten is dat de publiekrechtelijke waarborgen uit het oog kunnen worden verloren. De eventuele ontoelaatbaarheid van beschikkingvervangende overeenkomsten is, buiten het (hiervoor besproken) financiële recht, vooral te baseren op het feit dat de belangen van burgers niet voldoende zijn gewaarborgd. Te denken valt aan de materiële en procedurele waarborgen die mede met het oog op derden-belanghebbenden zijn opgenomen in de wettelijke regelingen die betrekking hebben op de beschikkingsbevoegdheid.

Het is echter niet geheel uitgesloten dat met deze belangen in de overeenkomst voldoende rekening wordt gehouden. Gedacht zou kunnen worden dat daardoor geen sprake is van onaanvaardbaar contractueel handelen. Wij zijn echter geneigd daar anders tegenaan te kijken, vanwege de bestuursrechtelijke rechtsbeschermingsmogelijkheden die aldus contractueel opzij geschoven kunnen worden. Een derde kan immers, als hij een belanghebbende is in de zin van art. I:2 Awb, bezwaar maken en beroep instellen bij de bestuursrechter tegen een beschikking. Deze derde heeft minder goede mogelijkheden om op te komen tegen een beschikkingvervangende overeenkomst, doordat hij daarbij geen partij is. Hij zou immers een actie bij de burgerlijke rechter moeten instellen waarin hij aanvoert dat het jegens hem onrechtmatig is de overeenkomst aan te gaan.

Voorts is er een reëel risico dat de rechtsbescherming meer gecompliceerd en versnipperd raakt als op een bepaald beleidsterrein zowel beschikkingen als beschikkingvervangende overeenkomsten naast elkaar kunnen voorkomen. Daarbij komt dat het zelfs niet geheel is uitgesloten dat de bestuursrechter in een concreet geval in de beschikkingvervangende overeenkomst zelf een appellabel besluit ziet,

I4I HR 4 april 20I4, AB 20I4/30I m.nt. F.J. van Ommeren (College voor Zorgverzekeringen/Stichting Zorggroep CHARIM c.s.).

I42 R.H. Happé, 'Fiscaal compromis. Op de grens van publiek- en privaatrecht', in: T. Hartlief \& C.J.J.M. Stolker (red.), Contracturijheid, Deventer: Kluwer 1999, p. 85; A.A. van Rossum, Vaststellingsovereenkomst, Deventer: Kluwer 200I, p. 54 en Huisman 2013b, p. 9.

I43 Vgl. HR 8 oktober I993, AB I994/299 m.nt. F.H. van der Burg (Marken). 
terwijl de burgerlijke rechter haar niet als besluit aanmerkt. In dergelijke gevallen kunnen beide soorten rechters van de overeenkomst kennisnemen. Dit kan gemakkelijk tot complicaties leiden. Het is vanuit het oogpunt van rechtseenheid en rechtszekerheid niet te verkiezen dat de geschillen daarover aan verschillende rechters kunnen worden voorgelegd. ${ }^{144}$ Voor de goede orde: het is hier dus niet het verschil in de aard van de rechtsbescherming tussen de burgerlijke rechter en de bestuursrechter (op grond van de veronderstelling dat de bestuursrechter de burger meer of toegankelijker rechtsbescherming zou bieden) die met zich zou brengen dat er voor beschikkingvervangende overeenkomsten minder plaats is, maar het risico op tegenstrijdige uitspraken van de burgerlijke rechter en de bestuursrechter in op zichzelf vergelijkbare gevallen. Al met al zien wij voor de beschikkingvervangende overeenkomst in beginsel weinig ruimte, zeker wanneer de beschikking vatbaar is voor bezwaar en beroep. Dit is anders voor de regelvervangende overeenkomst.

\section{Regelvervangende overeenkomsten}

Bij regelvervangende overeenkomsten dient met name gedacht te worden aan overeenkomsten die lagere wet- en regelgeving vervangen, zoals een algemene maatregel van bestuur of een ministeriële regeling, maar overeenkomsten als alternatief voor wetgeving in formele zin zijn zeker niet uitgesloten.

Niet ondenkbaar is overigens dat slechts van het treffen van wettelijke regels wordt afgezien, zonder dat er alternatieve (contractuele) regels voor in de plaats komen. Maar daarnaast komt het ook voor dat convenanten e.d. worden gesloten waarin van gebruik van een publiekrechtelijke regelgevingsbevoegdheid wordt afgezien en in plaats daarvan afspraken met betrokkenen zijn opgenomen.

Wanneer de overheid afziet van het gebruik van een (publiekrechtelijke) regelgevende bevoegdheid en in plaats daarvan een overeenkomst met betrokkenen sluit, rijst in het bijzonder de vraag of en in hoeverre de - veelal procedurele - belangen van betrokkenen en derden-belanghebbenden niet worden geschonden. Met andere woorden: doorkruist de overeenkomst niet op onaanvaardbare wijze de waarborgen waarmee de publiekrechtelijke weg is omgeven? Op het eerste gezicht heeft het daar mogelijk de schijn van, maar dat behoeft niet per se het geval te zijn. Het is denkbaar om bij het contracteren in vergelijkbare waarborgen te voorzien. Zo is ook hier besluitvorming door een collegiaal samengesteld bestuursorgaan mogelijk (bijvoorbeeld de ministerraad), kan er advies worden gevraagd, en behoort algemene bekendmaking van het eindresultaat (de overeenkomst) tot de mogelijkheden. Voor de centrale overheid schrijven de Aanwijzingen voor de convenanten dit ook voor. ${ }^{145}$ Wordt voor de totstandkoming van de overeenkomst in vergelijkbare waarborgen voorzien, dan hoeft het sluiten van een regelvervangende overeenkomst niet te leiden tot een onaanvaardbare doorkruising van de denkbare

I44 Zie in gelijke zin Scheltema \& Scheltema 20I3, p. 24I.

I45 Voor contracten op het niveau van de centrale overheid, die aangemerkt kunnen worden als 'convenanten' in de zin van de Aanwijzingen voor Convenanten (zie aanw. I) dient dit derhalve te gebeuren. Zo valt onder meer te wijzen op aanw. IO, II, I3, 24 en 25. Zie Stcrt. 2003, nr. I8, p. 9. 
publiekrechtelijk weg. ${ }^{\mathrm{I} 4}$ Probleem is evenwel dat terwijl dit soort waarborgen publiekrechtelijk grondig zijn verankerd, dit bij het sluiten van een regelvervangende overeenkomst niet het geval is. Partijen en vooral derden zijn dan veel meer afhankelijk van de bereidheid daartoe van het bestuursorgaan. Dit kan ertoe leiden dat in de wet opgenomen specifieke totstandkomingswaarborgen van een bepaalde regeling geheel in de wind worden geslagen; gedacht kan worden aan het omzeilen van de wettelijk verplichte inspraak van derden, zoals die bijvoorbeeld in art. 2I.6 lid 4 Wet milieubeheer is voorzien. Het laat zich goed denken dat het omzeilen van dergelijke verplichte inspraak een onaanvaardbare doorkruising kan opleveren van de publiekrechtelijke weg. ${ }^{\text {I47 }}$

Omdat tegen regelgeving geen rechtstreekse bestuursrechtelijke rechtsbescherming openstaat (art. 8:3 lid I sub a Awb), werpt het ontbreken van bestuursrechtelijke rechtsbescherming onzes inziens minder een dam op tegen het gebruik van regelvervangende overeenkomsten dan bij beschikkingvervangende overeenkomsten.

Zoals gezegd, kan niet alleen de bevoegdhedenovereenkomst maar ook de privaatrechtelijke overheidsovereenkomst worden gebruikt als alternatief voor een besluit (paragraaf 3.5). Behalve op publiekrechtelijke titel (het uitdrukkelijk niet gebruikmaken van een publiekrechtelijke regelgevingsbevoegdheid) kan op privaatrechtelijke titel een overeenkomst worden gesloten die tot functie heeft in de plaats te komen van een publiekrechtelijke regeling. Zo kunnen de gemeentelijke gronduitgiftevoorwaarden dezelfde of zelfs striktere voorwaarden bevatten dan het bestemmingsplan. De rechter pleegt de toelaatbaarheid van dit soort voorschriften te beoordelen aan de hand van het criterium van de onaanvaardbare doorkruising. Hij acht gemeentelijke gronduitgiftevoorwaarden die verder gaan dan het bestemmingsplan toelaatbaar. ${ }^{\mathrm{I} 48}$

Een enkele keer bevat de wet een specifieke voorziening voor een regelvervangende overeenkomst. Bij wijze van voorbeeld kan gedacht worden aan de anterieure grondexploitatieovereenkomst van art. 6.24 Wro. Deze overeenkomst komt voor partijen in de plaats van het exploitatieplan. Dit plan is evenals het bestemmingsplan verbindend voor de grondeigenaren van het exploitatiegebied. ${ }^{\mathrm{I} 9}$ Wanneer er een specifieke wettelijke voorziening is, moet een dergelijke overeenkomst in beginsel toelaatbaar worden geacht, wat niet wegneemt dat de concrete inhoud van de overeenkomst ongeoorloofd kan zijn. Aan de toepassing van de doorkruisingsformule wordt voor de beoordeling daarvan niet toegekomen, omdat de wet zelf al voorziet in een antwoord op de vraag of de contractuele weg in beginsel is toegestaan.

I46 S.E. Zijlstra, Convenanten (preadvies Vereniging voor de vergelijkende studie van het recht in België en Nederland), Zwolle: W.E.J. Tjeenk Willink I994, p. 33-34.

I47 J.A.E. van der Jagt, Milieuconvenanten gehandhaafd. Een juridisch onderzoek naar handhaafbaarheid en handhaving van Nederlandse milieuconvenanten en in het bijzonder klimaatconvenanten in het licht van de democratische rechtsstaat (diss. Utrecht), Den Haag: Boom Juridische uitgevers 2006, p. I59. Zie ook Huisman 2012, p. I6I-I62. Vgl. Zijlstra I994, p. 33-34.

I48 HR 8 juli I99I, AB I99I/659 m.nt. F.H. van der Burg (Kunst- en antiekstudio Lelystad) en HR 24 december 2004, AB 2005/58 m.nt. G.A. van der Veen (Chidda). Zie over de geoorloofdheid van dit soort voorwaarden paragraaf 4.2 .

I49 Zie uitvoeriger over de grondexploitatieovereenkomst, het exploitatieplan en de verhouding tussen deze twee: Groen 20I4, p. 339 e.v. en Van Buuren e.a. 20I4, p. 229 e.v. 
$\mathrm{Al}$ met al is er voor de regelvervangende overeenkomsten meer ruimte dan voor beschikkingvervangende overeenkomsten, aangezien relatief minder snel de materiele en formele waarborgen van derden op onaanvaardbare wijze worden doorkruist.

\subsection{De ruimte voor overheidsovereenkomsten en de te hanteren maatstaven}

Het verschilt per soort overheidsovereenkomst welke ruimte er is om te contracteren en aan de hand van welke maatstaven dit wordt beoordeeld. De ruimte om privaatrechtelijke overheidsovereenkomsten te sluiten wordt beoordeeld aan de hand van de algemene maatstaven die worden gehanteerd om de toelaatbaarheid van het gebruik van privaatrechtelijke middelen door de overheid te beoordelen, zoals de doorkruisingsformule, het leerstuk van misbruik van een privaatrechtelijke bevoegdheid en de algemene beginselen van behoorlijk bestuur.

Op bevoegdhedenovereenkomsten past de Hoge Raad de doorkruisingsformule niet uitdrukkelijk toe. De toelaatbaarheid wordt, zo leiden wij af uit de jurisprudentie, vooral bepaald door het wettelijk kader van de bevoegdheid waarover wordt gecontracteerd, met inbegrip van de strekking daarvan. Heeft het bestuur enige vorm van beslissingsruimte bij een publiekrechtelijke bevoegdheid, dan impliceert dit dat daarover in beginsel gecontracteerd kan worden. De toelaatbaarheid van contractuele bedingen waarin verplichtingen van de wederpartij van de overheid zijn opgenomen, wordt thans in de jurisprudentie ad hoc aan de hand van wisselende maatstaven beoordeeld; voldoende duidelijkheid lijkt daarbij te ontbreken. Het is daardoor naar onze mening vanuit het oogpunt van een uniforme rechtsontwikkeling en rechtszekerheid wenselijk dat voor wat betreft de toelaatbaarheid van bedingen in bevoegdhedenovereenkomsten, aansluiting wordt gezocht bij de ruimte die er is om (financiële) voorschriften en voorwaarden te verbinden aan publiekrechtelijke besluiten.

De uitvoeringsovereenkomst is in de Nederlandse juridische doctrine een nog weinig erkende en separaat geanalyseerde rechtsfiguur. Bij wijze van verkenning hebben wij kort een wettelijke en een buitenwettelijke uitvoeringsovereenkomst bekeken. De behoefte aan deze overeenkomst bestaat aan de zijde van het bestuursorgaan vooral in die gevallen dat het geen wettelijke titel heeft om eenzijdig afdwingbare verplichtingen op te leggen. Net als bij de bevoegdhedenovereenkomst hangt de toelaatbaarheid van de uitvoeringsovereenkomst sterk samen met het daarmee verband houdende besluit en het daarbij behorende wettelijke kader; ook hier is de overeenkomst te zien als een onderdeel van een bestuursrechtelijke rechtsbetrekking rondom een besluit. Voor de beantwoording van de vraag of en in hoeverre er ruimte is om dit soort overeenkomsten te sluiten, blijkt de doorkruisingsformule niet relevant. Het zijn met name het legaliteitsbeginsel en de inhoud en strekking van de wettelijke bevoegdheid waaraan de overeenkomst uitvoering geeft, waaraan relatief veel betekenis toekomt.

De verhouding tussen het publiekrechtelijke besluit en de uitvoeringsovereenkomst lijkt niet steeds voldoende doordacht en blijkt nog relatief veel vragen op te roepen. Het zelfde geldt, zij het in iets mindere mate, voor de bevoegdhedenovereenkomst. Het komt ons voor dat dit mede verklaard kan worden door de gebruikelijke, maar onzes inziens te beperkte fixatie op het Awb-besluit als meest centrale bestuursrechtelijke rechtsfiguur. Wanneer het bestuursrecht meer als een stelsel 
van rechtsbetrekkingen zou worden beschouwd, komen als vanzelf de uitvoeringsen de bevoegdhedenovereenkomst en hun verhouding met het daarmee samenhangende besluit meer in het vizier. Wij verwijzen graag naar ons eerdere pleidooi om het Nederlandse bestuursrecht langs deze route te doen ontwikkelen. ${ }^{150}$

De besluitvervangende overeenkomst ten slotte verdient aparte aandacht. Zowel privaatrechtelijke overheidsovereenkomsten als bevoegdhedenovereenkomsten kunnen worden gebruikt om publiekrechtelijke besluiten te vervangen. Het feit dat besluiten door verschillende soorten overeenkomsten kunnen worden vervangen, moet onzes inziens medebepalend zijn voor de inhoud van een geschikt beoordelingskader.

Anders dan bij andere bevoegdhedenovereenkomsten blijkt de doorkruisingsformule voor de beoordeling van de toelaatbaarheid van besluitvervangende overeenkomsten wel relevant te zijn. Daarvoor zijn twee redenen aan te dragen. Het op de wet en het specialiteitsbeginsel gebaseerde beoordelingskader van art. 3:3 Awb geeft te weinig houvast voor die gevallen dat de publiekrechtelijke titel slechts is het afzien van de uitoefening van de publiekrechtelijke bevoegdheid. Terwijl de ruimte om een bevoegdhedenovereenkomst te sluiten in beginsel goed kan worden beoordeeld aan de hand van het wettelijk kader en het doel van deze regeling, lijkt dit kader bij besluitvervangende bevoegdhedenovereenkomsten te beperkt. De toepassing van de doorkruisingsformule biedt evenwel een goed alternatief. In het bijzonder het tweede ijkpunt van de bescherming van de belangen van de burger kan niet goed worden gemist. Bovendien is het onwenselijk als er verschillende beoordelingskaders zouden zijn voor de privaatrechtelijke en de publiekrechtelijke besluitvervangende overeenkomst. Ook dit pleit ervoor de doorkruisingsformule wel van toepassing te achten op de bevoegdhedenovereenkomsten die beogen besluiten te vervangen. Dat de doorkruisingsformule bij deze besluitvervangende overeenkomsten wel relevant is, is uit een oogpunt van eenheid van recht als positief te beoordelen, omdat anders op verschillende soorten overeenkomsten met een besluitvervangend karakter uiteenlopende beoordelingsmaatstaven toegepast zouden worden, hetgeen tot ongerijmdheden kan leiden. Beide redenen tezamen genomen, ligt het in de rede om op de besluitvervangende overeenkomst de doorkruisingsformule van toepassing te achten, ook als het de beoordeling van de toelaatbaarheid van de besluitvervangende bevoegdhedenovereenkomst betreft.

De doorkruisingsformule is ook bij besluitvervangende overeenkomsten niet de enige te hanteren maatstaf. Het komt voor dat met een beroep op het wettelijk systeem (legaliteitsbeginsel) de beschikkingvervangende overeenkomst ongeoorloofd wordt geacht; te denken valt aan beschikkingvervangende overeenkomsten in het belastingrecht. Mogelijk komt dit door het sterk verankerde fiscale legaliteitsbeginsel, zie art. Io4 Grondwet.

De ruimte om beschikkingvervangende overeenkomsten te sluiten is naar onze mening zeer beperkt, aangezien met name de publiekrechtelijk gegeven materiële en formele waarborgen van de burger, in het bijzonder ook op het terrein van de rechtsbescherming, daardoor te zeer in de knel kunnen komen. Voor regelvervangende overeenkomsten is meer ruimte, omdat de hiervoor genoemde waarborgen minder snel op onaanvaardbare wijze worden doorkruist.

I50 Van Ommeren \& Huisman 20I3, p. 47 e.v. en p. 93 e.v. 


\section{$5 \quad$ Epiloog}

\section{I Twee wegen?}

Motieven voor de privaatrechtelijke weg

De rechtspraak over de tweewegenleer overziend, blijkt al vlug dat een belangrijke drijfveer voor de overheid om de privaatrechtelijke weg te prefereren, is dat langs die weg aan de burger verdergaande verplichtingen kunnen worden opgelegd dan op grond van het publiekrecht mogelijk is. De overheid beoogt deze verplichtingen zowel in plaats van als in aanvulling op de haar toegekende publiekrechtelijke bevoegdheden op te leggen. Dat is bepaald geen futiliteit. Immers, juist voor het opleggen van verplichtingen is in het publiekrecht in beginsel steeds een specifieke wettelijke grondslag vereist.

Een andere beweegreden voor de overheid om in het kader van de haar toevertrouwde taak voor de privaatrechtelijke weg te kiezen, is dat deze weg haar meer zekerheden biedt. Dit zien we in het bijzonder bij de handhaving, alwaar de privaatrechtelijke weg een preventief oordeel van de rechter vereist. Het is om die reden dat wij juist ten aanzien van de handhaving de koers van de burgerlijke rechter te streng vinden en de overheid - meer dan nu naar geldend recht is toegestaan - de vrije keuze zouden willen laten te kiezen voor de bestuursrechtelijke of de privaatrechtelijke handhavingsweg. Overigens kan de privaatrechtelijke weg ook voor de burger aantrekkelijker zijn, met name in die gevallen dat een financiële dienstverlener terecht of onterecht veronderstelt dat zulks aan hem meer zekerheden biedt.

Een derde te noemen beweegreden voor de overheid om voor de privaatrechtelijke weg te kiezen is het verwerven van instemming van de direct betrokkenen. De meest voor de hand liggende rechtsfiguur is in die gevallen de overeenkomst. De keuze voor de overeenkomst lijkt wellicht vooral aan de orde in die gevallen dat er rechtens geen mogelijkheid is om verplichtingen eenzijdig op te leggen. Vanuit juridisch oogpunt is er dan immers geen alternatief. Maar de praktijk leert dat ook in gevallen dat zulks juridisch niet per se noodzakelijk is, er toch - op grond van overwegingen van sociaal verkeer of andere overwegingen - een voorkeur voor de overeenkomst kan bestaan.

Voortgaande rechtsontwikkeling: de verkleinde ruimte voor de privaatrechtelijke weg

Er is een vrij duidelijke ontwikkeling in de rechtspraak waar te nemen waarbij aan de overheid geleidelijk aan minder ruimte toekomt om voor de privaatrechtelijke weg te kiezen. De rechtspraak aan de hand waarvan de formule van de onaanvaardbare doorkruising is uitgewerkt, geeft daarvan blijk. Het aloude criterium van het wettelijk beletsel vereiste in wezen een bevestigend antwoord op de vraag of de wettelijke voorzieningen exclusief waren bedoeld, wilde de privaatrechtelijke weg ongeoorloofd zijn. Dat antwoord werd vóór Windmill niet snel gegeven, omdat de wet niet zo werd uitgelegd, behalve als zulks vrij expliciet bleek. De doorkruisingsformule is een stap strenger en verkleint de mogelijkheden voor de privaatrechtelijke weg. Uit de meer recente rechtspraak, met name het arrest Amsterdam/Geschiere, 
blijkt bovendien dat als de belangenafweging reeds in het publiekrechtelijke kader is verricht, deze niet in een privaatrechtelijk vervolgtraject kan worden heroverwogen; met andere woorden: de publiekrechtelijke afweging is dominant. Ook dit kan de ruimte voor de privaatrechtelijke weg verkleinen. Een en ander betekent evenwel niet dat het uitgangspunt van de tweewegenleer is losgelaten, ofschoon dit wel met veel nadruk in de literatuur was bepleit.

\section{Zuivere of onzuivere tweewegensituaties?}

In dit preadvies zijn wij uitgegaan van de veronderstelling dat de overheid zowel in plaats van als in aanvulling op het publiekrecht van privaatrechtelijke middelen gebruik wenst te maken. In de literatuur wordt wel een onderscheid gemaakt tussen zuivere en onzuivere tweewegensituaties. Daarmee wordt echter op een ander onderscheid gedoeld. Van een onzuivere tweewegensituatie is sprake wanneer de overheid privaatrechtelijk handelt terwijl de publiekrechtelijke weg niet of nog niet beschikbaar is. ${ }^{\text {III }}$ Van een zuivere tweewegensituatie is uiteraard sprake als voor de overheid in beginsel beide wegen ter beschikking staan. Wij hebben echter bewust van het gebruik van dit onderscheid afgezien, omdat daaraan (evenmin) maar moeilijk eenduidig rechtsgevolgen kunnen worden verbonden. Ook in de literatuur wordt de doorkruisingsformule op beide soorten situaties toegepast.

Het is evenzeer van belang de andere kant van de twee wegen, de privaatrechtelijke weg, meer precies onder de loep te nemen. Ook in dat traject doen zich (als het ware) zuivere en onzuivere situaties voor. Beschouwd naar de titel van het bestuurshandelen zijn er niet alleen echte privaatrechtelijke wegen, maar ook andere die wij als publiekrechtelijk hebben aangeduid, ofschoon ze naar geldend recht als privaatrechtelijk worden bestempeld. Te denken valt met name aan de verschillende soorten publiekrechtelijke overeenkomsten.

\subsection{Overheidsovereenkomsten}

Soorten overeenkomsten

Het is niet gemakkelijk goed grip te krijgen op de ruimte die er is voor het aangaan van een overheidsovereenkomst. De toename van het aantal publiekrechtelijke bevoegdheden vormde aanleiding scherper te kijken naar de verhouding tussen de gebruikmaking van de overheidsovereenkomst en de uitoefening van de publiekrechtelijke bevoegdheid. Teneinde meer precies te bezien aan de hand van welke maatstaven de ruimte moet worden beoordeeld die de overheid heeft om overeenkomsten te sluiten, hebben wij de publiekrechtelijke overeenkomsten nader onderscheiden in de bevoegdhedenovereenkomst en de uitvoeringsovereenkomst. Zowel de privaatrechtelijke overeenkomst als de bevoegdhedenovereenkomst kunnen bovendien worden gebruikt om een besluit te vervangen. Bij de publiekrechtelijke besluitvervangende overeenkomst is de contractueel vastgelegde toezegging de

I5I Duijkersloot e.a. 20Io, p. I8 en L.J.A. Damen e.a., Bestuursrecht. Deel 1. Systeem. Bevoegdheid. Bevoegdheidsuitoefening. Handhaving, Den Haag: Boom Juridische uitgevers 2013, p. 597. 
publiekrechtelijke bevoegdheid niet te gaan uitoefenen aan overheidszijde de basis voor het aangaan van deze overeenkomst.

Voor de toelaatbaarheid van de privaatrechtelijke overheidsovereenkomsten is primair de doorkruisingsformule bepalend, zij het dat zij niet de enige beoordelingsmaatstaf is. Het is echter goed mogelijk de andere maatstaven te begrijpen in hun samenhang met de doorkruisingsformule. Ook voor de andere soorten overeenkomsten hebben wij ernaar gestreefd om per rechtsfiguur in beginsel één beoordelingskader te ontwikkelen. De publiekrechtelijke overeenkomsten moeten in onze ogen niet worden getoetst aan de doorkruisingsformule. Voor de bevoegdhedenovereenkomst is het beoordelingskader veeleer gebaseerd op het legaliteitsbeginsel met een zwaar accent op de doelgebondenheid van de publiekrechtelijke overeenkomst; dit vanwege de sterke samenhang tussen overeenkomst en uitvoeringsbesluit. Ook bij de uitvoeringsovereenkomst is de ruimte om te contracteren sterk afhankelijk van het bij het besluit behorende wettelijke kader en komt aan het legaliteitsbeginsel relatief veel betekenis toe. De besluitvervangende overeenkomsten moeten naar onze mening echter wel primair worden getoetst aan de doorkruisingsformule, ook als het om een bevoegdhedenovereenkomst gaat (dit laatste is dus een uitzondering op de hiervoor tot uitdrukking gebrachte regel). Wij zien voor de regelvervangende overeenkomst meer ruimte dan voor de beschikkingvervangende overeenkomst. Uit de analyse van de verschillende soorten overeenkomsten blijkt al met al dat zij niet alleen in een verschillende verhouding tot de publiekrechtelijke bevoegdheid kunnen staan, maar ook dat de ruimte om overheidsovereenkomsten te sluiten (daardoor) op verschillende wijzen door het publiekrecht wordt genormeerd.

\section{Verpubliekrechtelijking van het overheidsovereenkomstenrecht}

Het is niet ongebruikelijk om erop te wijzen dat er sprake is van een zogeheten 'verpubliekrechtelijking' van de rechtsfiguur van de overheidsovereenkomst. ${ }^{152}$ Onze bevindingen in dit preadvies sluiten daarbij aan. Met de verpubliekrechtelijking wordt met name gedoeld op de toenemende betekenis van normen van publiekrechtelijke herkomst voor de ruimte die de overheid heeft om overeenkomsten aan te gaan. Veelal wordt dan gedoeld op de algemene wettelijke regelingen die er in verschillende rechtsstelsels bestaan voor het gebruik van bepaalde overheidscontracten. In Europees verband moet zeker ook de betekenis van het aanbestedingsrecht worden genoemd. Daarbij kan ook gedacht worden aan de Model Rules die door ReNEUAL zijn opgesteld voor het gebruik van publiekrechtelijke overeenkomsten door autoriteiten van de Europese Unie. Naar Nederlands recht blijkt die verpubliekrechtelijking met name ook doordat op privaatrechtelijke overheidsovereenkomsten normen van publiekrechtelijke herkomst van toepassing zijn, zoals de algemene beginselen van behoorlijk bestuur.

Maar er is meer. Het blijkt dat de rechtsrelatie van de publiekrechtelijke overeenkomsten met de uitoefening van publiekrechtelijke bevoegdheden eveneens de ruimte om dit soort overeenkomsten te sluiten beïnvloedt. Dat valt duidelijk te zien bij de bevoegdhedenovereenkomst, die ontoelaatbaar is indien zij voor een ander

I52 Van Ommeren 20I4, p. I29, I30. 
doel wordt gebruikt dan waarvoor de wettelijke bevoegdheid waarover gecontracteerd is, is bestemd. Niet alleen de publiekrechtelijke bevoegdheid, maar ook de daarmee samenhangende overeenkomst is doelgebonden. We zien het ook bij de uitvoeringsovereenkomst, alwaar onrechtmatigheden en onregelmatigheden bij de (daaraan voorafgaande) besluitvorming van invloed zijn op de ruimte om deze overeenkomst geldig aan te gaan. Deze, in hoofdzaak wettelijke, toetsingskaders voor de uitoefening van de publiekrechtelijke bevoegdheid bepalen aldus mede de ruimte om dit soort overheidsovereenkomsten te kunnen sluiten.

\subsection{De bijzondere positie van de overheid in het Nederlandse privaatrecht}

De positie van de overheid in het Nederlandse privaatrecht is in die zin bijzonder dat haar zowel privaatrechtelijke middelen als publiekrechtelijke bevoegdheden ten dienste staan, hetgeen tot een geheel eigen problematiek leidt: de tweewegenleerproblematiek. Er is inmiddels een verfijnd stelsel ontstaan waarin normen van publiekrechtelijke en privaatrechtelijke herkomst met elkaar interfereren en de tweewegenleer nader invullen. Dat komt in het bijzonder door de steeds dominantere betekenis van de publiekrechtelijke bevoegdheden in rechtsverhoudingen die traditioneel - en naar geldend recht nog steeds - als privaatrechtelijk worden aangemerkt. We zijn daarmee ver verwijderd geraakt van een rechtsstelsel waarin het bestaan van publiekrechtelijke bevoegdheden niet veel meer kon betekenen dan dat zij de privaatrechtelijke weg afsnijden wanneer zij exclusief waren bedoeld.

De ruimte die het recht voor privaatrechtelijk overheidshandelen laat, is niet gefixeerd maar aan ontwikkeling onderhevig. Zij is bovendien naar onze mening op onderdelen vatbaar voor aanpassing. Soms beperkt de rechter de ruimte voor privaatrechtelijk overheidshandelen te veel. Zo zien wij niet in waarom de doorkruisingsformule in de weg zou moeten staan aan (preventieve) handhaving via de civiele rechter. Op andere punten achten wij het aangewezen om andere maatstaven dan de doorkruisingsformule te hanteren, waardoor de thans bestaande ruimte voor privaatrechtelijk overheidshandelen mogelijk anders wordt ingevuld. Zo vinden wij het wenselijk om voor de beoordeling van de toelaatbaarheid van bedingen in bevoegdhedenovereenkomsten aan te sluiten bij de stringente maatstaven die de bestuursrechter hanteert om de toelaatbaarheid van het verbinden van voorschriften en voorwaarden aan besluiten te beoordelen. Verder dient naar ons oordeel de positie van derden-belanghebbenden bij overheidsovereenkomsten te worden versterkt in die gevallen waarin er een nauw verband is tussen de overeenkomst en publiekrechtelijke besluitvorming.

In het moderne overheidsovereenkomstenrecht komt de spanning tussen de wens om op een effectieve manier het overheidsbeleid te verwezenlijken (governance) en de vraag in hoeverre het geoorloofd is van het contract als alternatief overheidsinstrument gebruik te maken (law) prominent naar voren. Om beide in balans te laten zijn, zijn duidelijke en eenduidige normatieve beoordelingskaders onontbeerlijk. 